UNIVERSIDADE DE SÃO PAULO

FACULDADE DE ECONOMIA, ADMINISTRAÇÃO E CONTABILIDADE DEPARTAMENTO DE ADMINISTRAÇÃO PROGRAMA DE PÓS-GRADUAÇÃO EM ADMINISTRAÇÃO

FACILITADORES E DIFICULTADORES NA IMPLEMENTAÇÃO DE UM NEGÓCIO INCLUSIVO EM TRÊS PAÍSES DE DIFERENTES CONTINENTES

Anita Maria de Moura

Orientadora: Profa. Dra. Graziella Maria Comini 
Prof. Dr. João Grandino Rodas

Reitor da Universidade de São Paulo

Prof. Dr. Reinaldo Guerreiro

Diretor da Faculdade de Economia, Administração e Contabilidade

Prof. Dr. Adalberto Américo Fischmann

Chefe do Departamento de Administração

Prof. Dr. Lindolfo Galvão de Albuquerque

Coordenador do Programa de Pós-Graduação em Administração 


\title{
FACILITADORES E DIFICULTADORES NA IMPLEMENTAÇÃO DE UM NEGÓCIO INCLUSIVO EM TRÊS PAÍSES DE DIFERENTES CONTINENTES
}

\author{
Dissertação apresentada ao \\ Departamento de Administração da \\ Faculdade de Economia, Administração \\ e Contabilidade da Universidade de São \\ Paulo como requisito para a obtenção do \\ título de Mestre em Administração.
}

Orientadora: Profa. Dra. Graziella Maria Comini

\author{
Versão Corrigida \\ (versão original disponível na Unidade que aloja o Programa)
}

SÃO PAULO

2011 
FICHA CATALOGRÁFICA

Elaborada pela Seção de Processamento Técnico do SBD/FEA/USP

\section{Moura, Anita Maria de}

Facilitadores e dificultadores na implementação de um negócio inclusivo em três países de diferentes continentes / Anita Maria de Moura. - São Paulo, 2011.

$122 \mathrm{p}$.

Dissertação (Mestrado) - Universidade de São Paulo, 2011.

Orientador: Graziella Maria Comini.

1.Empresas não lucrativas 2. Empreendedorismo 3. Organização não-governamental 4. Organização social I. Universidade de São Paulo. Faculdade de Economia, Administração e Contabilidade. II. Título.

$$
\text { CDD }-658.401
$$


Ao meu amado avô Niasi Saliby.

(in memoriam) 
Agradeço a todos que me auxiliaram nesta conquista. Primeiramente, agradeço ao Howard Weinstein, que se tornou um grande amigo nos últimos dois anos. Obrigada pelas lições que não são ensinadas nas grandes faculdades, pelo seu tempo em responder todas minhas perguntas e sobretudo, por fazer deste mundo um lugar melhor.

Agradeço à Prof ${ }^{a}$ Graziella Comini, que sempre esteve presente não apenas como orientadora, mas como amiga e conselheira. Obrigada pelos incentivos e por toda confiança.

Agradeço ao Prof. Cláudio Pinheiro Machado e ao Prof. Armindo Teodósio pelas contribuições valiosas e por terem aceitado participar da avaliação deste trabalho.

Agradeço aos amigos que fiz durante estes anos de FEA e que me ajudaram a encontrar o caminho que buscava: Márcio Moran, por ter me apresentado o Solar Ear; Hugo Matsuzaki, pela parceria e amizade; Marina Carrilho, por sua enorme amizade e por estar sempre presente nos momentos mais difíceis; Márcia Farah e Guilherme Cuchierato, pela amizade e por todo o apoio que ofereceram.

Agradeço à minha família, aos meus pais, José Moura e Célia Moura, pelo tanto que investiram em mim a vida toda. Minha eterna gratidão e amor. Aos meus irmãos, Gabriel e Mirian, por sempre me apoiarem nas minhas decisões. Ao meu avô, pelo interesse e preocupação com meu futuro. À $\mathrm{Ci}$ e Miguel, pelos ensinamentos e carinho. Obrigada ao meu marido, Selim Guvener, pela paciência, suporte, amor e dedicação. 


\section{RESUMO}

Em países em desenvolvimento tem sido freqüente o surgimento de alternativas para combater o alto déficit social. Neste sentido, observa-se desde a década de 1990 um grande crescimento de ações filantrópicas por parte de empresas privadas bem como a intensificação da atuação de organizações da sociedade civil. Há 20 anos, empresas e sociedade civil eram assuntos distantes, com alta resistência para trabalhar de forma colaborativa. Passados onze anos do século XXI, esta realidade alterou-se de forma brutal. Hoje o diálogo não apenas é possível, mas também é visto como necessário para obtenção de uma relação ganha-ganha. Além do fenômeno das alianças intersetoriais, é possível também observar o surgimento de um novo tipo de organização que combina dois objetivos que antes eram vistos como incompatíveis: sustentabilidade financeira e geração de valor social. Empresas sociais, negócios inclusivos e negócios sociais são alguns dos termos usados atualmente para explicar as organizações que visam solucionar problemas sociais com eficiência e sustentabilidade financeira por meio de mecanismos de mercado. O presente estudo tem por objetivo discutir os vários fatores que facilitam e dificultam a implementação de um negócio inclusivo. Um modelo teórico foi desenvolvido e um estudo de caso empírico comparou uma iniciativa de negócio inclusivo que opera em Botsuana, Brasil e Jordânia. Os Fatores Críticos de Sucesso e a análise estratégica do Ecossistema apontou os facilitadores e dificultadores da implementação do negócio inclusivo nestes três países. Os resultados giram em torno do comprometimento da organização com seu ecossistema, porém riscos devem ser levados em conta.

Palavras-chave: empresas sociais, negócios inclusivos, negócios sociais. 


\begin{abstract}
Many alternative means of combating high social deficits have been proposed for emerging countries. Since the 1990s there has not only been an increase in philanthropic activity by private enterprise, but also an intensification in the role played by civil society organizations. Twenty years ago, business and civil society were two separate subjects, strongly resistant to collaboration. Eleven years into the twenty-first century, this reality has changed dramatically. Today dialogue is not only possible, but essential for a win-win relationship. Besides the phenomenon of inter-sectorial alliances, it is also possible to observe the emergence of a new type of organization, one which combines two objectives previously thought incompatible: financial sustainability and social value generation. Social enterprises, inclusive businesses and social businesses are some of the terms currently used to refer to organizations that aim to solve social problems efficiently and sustainably using market mechanisms. The present study aims to discuss various factors that facilitate or hinder the implementation of a social business. A theorical model will be developed and it will be presented a comparative empirical case study of an organization with operations in Botswana, Brazil and Jordan. Critical Success Factors and the strategic evaluation of the ecosystem show the factors that facilitated and hindered the implementation of the inclusive business in these three countries. One of the results is the organizations commitment with its ecosystem, but some risks should be taken into account.
\end{abstract}

Key words: social enterprises, inclusive businesses and social businesses 


\section{SUMÁRIO}

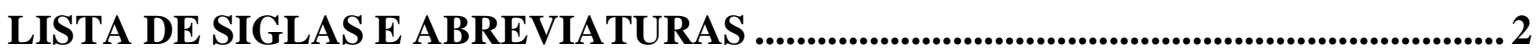

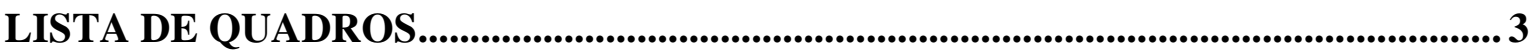

1. Definição do problema de investigação ............................................................................... 4

1.1 Introdução

$1.2 \quad$ Problema de investigação ............................................................................................

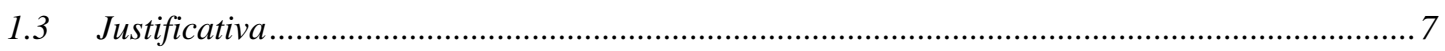

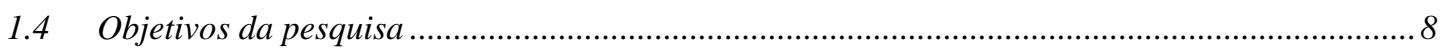

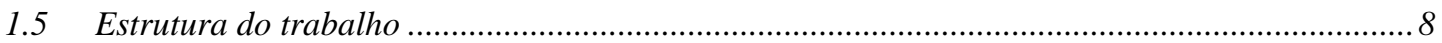

2. Referencial teórico ............................................................................................................ 10

2.1 Ecossistema Orientado para o Mercado dos Negócios Inclusivos .............................................. 10

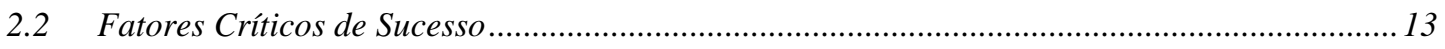

2.3 Contexto Histórico: Negócios Inclusivos ......................................................................... 15

2.4 Evolução do conceito teórico de negócios inclusivos .................................................................. 19

3. Procedimentos metodológicos .....................................................................4 41

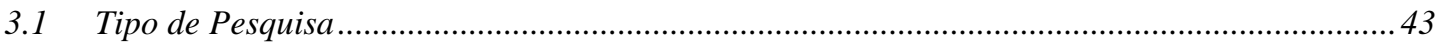

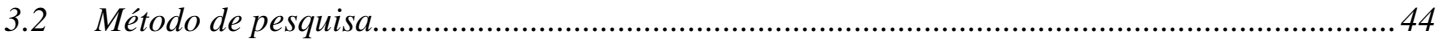

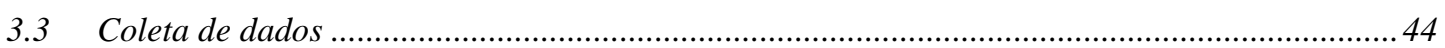

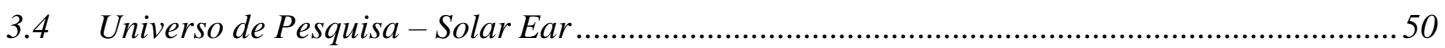

4. Análise do estudo de caso ......................................................................................................... 53

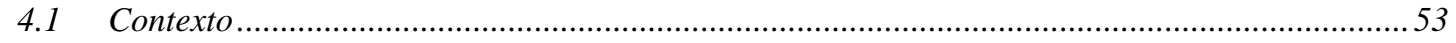

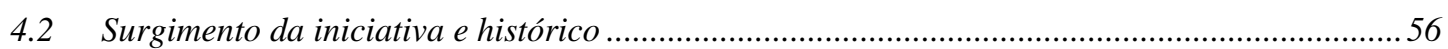

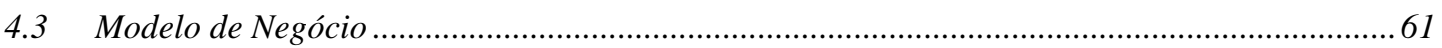

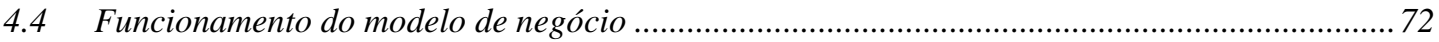

5. Considerações Finais ................................................................................... 88

REFERÊNCIAS BIBLIOGRÁFICAS ................................................................................. 94

Anexo 1 - Método do levantamento bibliográfico .............................................................. 109

Anexo 2 - Roteiro de entrevista ..................................................................................... 113

Anexo 3 - Protocolo de investigação para estudo de caso .............................................. 119 


\section{LISTA DE SIGLAS E ABREVIATURAS}

BSC: Balanced Score Card

CAPES: Coordenação de Aperfeiçoamento de Pessoal de Nível Superior

CISEPO: The Canadian International Scientific Exchange Program

CSF: Critical Success Factors

EBSCO: Research Database - Base de Dados para Pesquisa

EMES: Emergence of Social Enterprise in Europe

EnAnpad: Encontro da Associação Nacional de Pós-graduação e Pesquisa em Administração

FCS: Fatores Críticos de Sucesso

ISI: Research Database - Base de Dados para Pesquisa

L3C: Low-profit Limited Liability Company

MIT: Massachusetts Institute of Technology

NASA: National Aeronautics and Space Administration

OECD: Organization for Economic Co-operation and Development

OMS: Organização Mundial de Saúde

ONG: Organizações Não Governamentais

OS: Organização Social

PROQUEST: Research Database - Base de Dados para Pesquisa

RSS: Royal Scientific Society of Jordan

SEKN: Social Enterprise Knowledge Network

SEMEAD: Seminários em Administração

SUS: Sistema Único de Saúde

USAID: United States Agency for International Development

WISE: Work Integration Social Enterprise 


\section{LISTA DE QUADROS}

Quadro 1 - Diferentes visões dos negócios sociais .................................................. 36

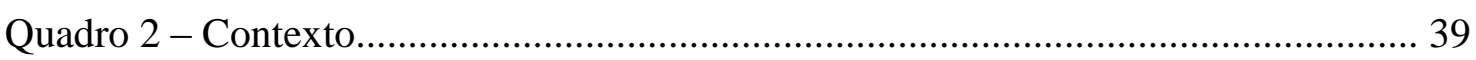

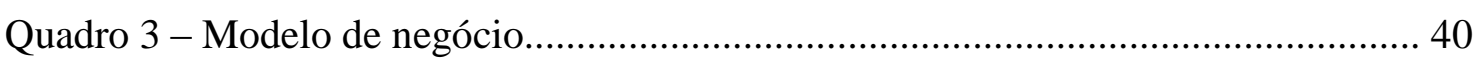

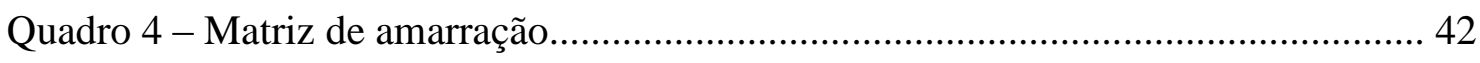

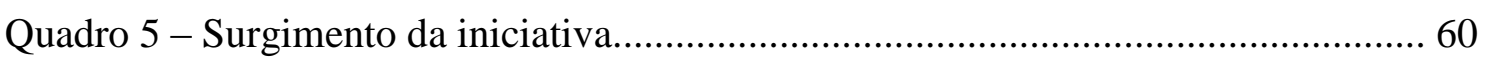

Quadro 6 - FCS: Pilares e contrapartida da organização........................................ 65

Quadro 7 - Facilitadores na implementação do Solar Ear....................................... 71

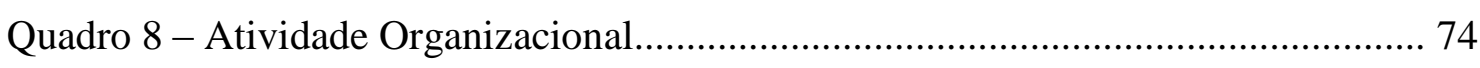

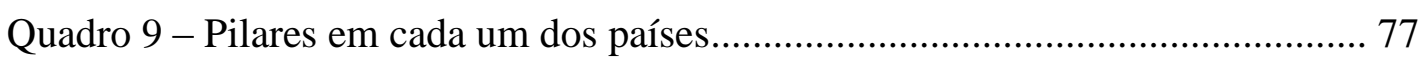

Quadro 10 - Contrapartida da organização......................................................... 78

Quadro 11 - Cadeia de valor nas três unidades.................................................. 81

Quadro 12 - Comprometimento com o ecossistema............................................. 90

Quadro 13 - Lista de Journals CAPES qualificação A1 na área de administração...... 110 


\section{DEFINIÇÃO DO PROBLEMA DE INVESTIGAÇÃO}

\subsection{Introdução}

Em países emergentes, cada vez mais é possível encontrar iniciativas que promovam benefícios para setores excluídos da sociedade. A existência de ações filantrópicas informais, associações, organizações da sociedade civil de interesse público, sustentabilidade organizacional e o crescimento da responsabilidade corporativa são temas que já são amplamente debatidos; agora porém, discute-se o surgimento de organizações que cada vez mais se especializam em solucionar problemas sociais com a mesma eficiência e sustentabilidade financeira das tradicionais organizações de mercado.

O surgimento destas iniciativas está relacionado ao fato de que as organizações modernas se adaptam com extrema rapidez às necessidades do ambiente. Assim, ao se falar em atuação social é possível identificar dois fenômenos entre as organizações: (i) as tradicionais organizações sem fins lucrativos buscam cada vez mais se profissionalizar e encontram sua sustentabilidade financeira através de múltiplas fontes de receitas; (ii) empresas que visam o lucro se tornam agentes de transformação social e ambiental, seja por consciência em relação aos problemas da sociedade e meioambiente, seja por pressão da sociedade e governo em adotar uma postura mais responsável.

Empresas sociais (social enterprise), negócios inclusivos (inclusive business) e negócios sociais (social business) são alguns dos termos usados atualmente para explicar essa nova interação entre mecanismos de mercado e setores excluídos da sociedade. Por serem temas muito recentes, quase não existem produções acadêmicas e o entendimento sobre as características específicas dessas organizações ainda não é homogêneo.

O termo negócio social será utilizado neste trabalho, de forma geral, para designar este novo fenômeno, enquanto que o termo negócio inclusivo será utilizado para designar um sub-grupo específico dos negócios sociais. Assim sendo, a definição adotada de negócios inclusivos é: toda organização que tem por objetivo melhorar a qualidade de 
vida de pessoas em vulnerabilidade social, por meio de uma atividade de mercado, utilizando práticas empresariais, gerando rentabilidade econômica e reinvestindo seus dividendos em sua missão social.

Esta definição foi criada a partir do levantamento das três principais correntes que explicam os negócios sociais, principalmente da perspectiva de países emergente. A perspectiva européia, nascida da tradição de economia social (associativismo, cooperativismo), apresenta a atuação de organizações privadas com forte apelo para finalidades públicas (BULL, 2006; GUNN et al, 2008; BORGAZA, GALERA, 2009); a norte-americana, entendida basicamente como organizações privadas, com lógica de mercado, dedicadas a soluções de problemas sociais (DIOCHON, ANDERSON, 2009; TREXLER, 2008; YOUNG, 2009) e uma terceira corrente, que inclui as iniciativas de países emergentes com foco principalmente na redução da pobreza e transformação das condições sociais dos indivíduos marginalizados (YUNUS, 2007).

O presente estudo visa analisar os fatores facilitadores e dificultadores da implementação dos negócios inclusivos a partir de uma sistematização teórica e estudo empírico comparativo de uma iniciativa presente em três países de diferentes continentes. O estudo levará em conta as variáveis locais de um negócio inclusivo e os fatores que contribuem positivamente ou negativamente para sua implementação em três diferentes realidades.

A escolha da iniciativa se deu pelo fato dela apresentar uma atuação reconhecida por prêmios humanitários internacionais e mídia internacional; por atuar em países pobres, emergentes e/ou em situação de conflito; por se utilizar de mecanismos de mercado como meio para a transformação social, isto é, a venda de produtos; e por fim, pela proximidade da autora, facilitando o acesso a dados secundários e aos entrevistados.

A iniciativa a ser estudada será a Solar Ear que, por meio da profissionalização e emprego de jovens $\operatorname{surdos}^{1}$, faz a montagem de aparelhos auditivos, recarregadores

\footnotetext{
${ }^{1}$ Entre os jovens que atuam no Solar Ear Brasil, o termo "surdo"é preferido e, por respeito a eles, será adotado neste trabalho.
} 
solares e baterias recarregáveis de aparelhos auditivos. Estes produtos possuem preço mais acessível, se comparado aos outros produtos no mercado e são distribuídos para pessoas de menor poder aquisitivo, focando principalmente, crianças com deficiência auditiva em países em desenvolvimento. A iniciativa permite que pessoas fisicamente e economicamente excluídas da sociedade obtenham um equipamento que possui a inovação tecnológica de baterias recarregáveis solares, além de profissionalizar e empregar jovens surdos que nunca tiveram anteriormente outra oportunidade de trabalho.

A partir da análise do estudo de caso serão levantadas as características deste negócio inclusivo e os fatores facilitadores e dificultadores que levaram à implementação desta iniciativa em diferentes realidades: Botsuana, Brasil e Jordânia

Acredita-se que, com a sistematização teórica, a proposta de um modelo teórico e a análise do caso possa-se contribuir para próximos estudos acadêmicos sobre negócios inclusivos.

\subsection{Problema de investigação}

A problemática da pesquisa está ligada ao crescente aparecimento de organizações que visam solucionar problemas sociais por meio de uma atividade econômica. Essas organizações possuem algumas características peculiares e buscam consolidação no mercado, visto que praticam a comercialização de produtos ou a prestação de serviços. Porém, o conceito de negócios inclusivos, utilizado neste trabalho, vai além da combinação sustentabilidade financeira e geração de valor social, pois prevê a efetiva inserção de pobres e minorias no negócio social.

Neste estudo, busca-se analisar os fatores facilitadores e dificultadores dos negócios inclusivos a partir de uma sistematização teórica e estudo empírico comparativo de uma iniciativa presente em três países de diferentes continentes. Sendo assim, o presente estudo pretende responder à seguinte pergunta-problema: quais são as características de um negócio inclusivo e quais fatores contribuem para sua implementação? 
Para que se possa compreender de forma mais clara essa pergunta-problema será desenvolvida as definições operacionais dos termos utilizados, isto é, o que se entende por cada termo da pergunta-problema.

As "características de um negócio inclusivo" são analisadas do ponto de vista da teoria de ecossistema orientado para o mercado (Market-based Ecosystem), observando tanto a cadeia de valor da organização, como aspectos de interação com outros atores do ecossistema. A teoria sobre ecossistema será desenvolvida de forma mais aprofundada no capítulo de referencial teórico, assim como toda discussão sobre negócios inclusivos.

O termo "implementação", neste estudo, é definido como o processo vivenciado pela organização desde sua criação até o momento do início da geração de impacto social positivo mensurável e o atingimento da auto-sustentação financeira.

Para se compreender de que forma a iniciativa Solar Ear busca atingir um equilíbrio entre esses dois aspectos, será feita uma análise dos fatores que contribuem positivamente e negativamente para o atingimento dos objetivos do negócio inclusivo nos três países: Botsuana, Brasil e Jordânia. Esta análise terá como base a teoria de fatores críticos de sucesso, que também será aprofundada no capítulo de referencial teórico.

Sendo assim, o estudo visa levantar as características de um negócio inclusivo existente em três diferentes países pobres ou em desenvolvimento, por meio de uma análise dos ecossistemas, compreendendo os fatores críticos de sucesso na implementação de seu modelo de negócio.

\subsection{Justificativa}

Um grande número de trabalhos acadêmicos tem trazido questões como a sustentabilidade, o impacto de ações de responsabilidade social corporativa, alianças e parcerias entre Estado, empresas privadas e o terceiro setor, além de diversos outros temas ligados ao desenvolvimento deste último. Porém, ainda são muito recentes os estudos que debatem a questão dos negócios sociais, negócios inclusivos e empresas 
sociais. Para ilustrar esse fato, em uma primeira etapa de coleta de dados para o presente trabalho foi realizado um amplo levantamento em bases nacionais e internacionais e apenas cento e oito artigos foram encontrados, dos quais noventa e cinco foram escritos nos últimos cinco anos, mostrando que se trata de um tema ainda pouco debatido ${ }^{2}$.

Além da relevância teórica, este trabalho contribui para a academia com seu estudo empírico. O estudo de caso compara a iniciativa Solar Ear, que está presente em três países pobres ou em desenvolvimento e localizados em diferentes continentes: Botsuana, Brasil e Jordânia. As diferenças culturais de cada um dos países e a análise do aspecto de gestão de cada uma das unidades do negócio inclusivo facilita a compreensão da complexidade do tema, bem como descreve as dificuldades encontradas em diferentes contextos.

\subsection{Objetivos da pesquisa}

O objetivo do presente trabalho é analisar as características de um negócio inclusivo e os fatores que facilitam ou dificultam sua implementação.

Mais especificamente, pretende-se (i) discutir as diferentes perspectivas sobre os negócios sociais e negócios inclusivos, ampliando o escopo de análise (ii) analisar as características de um modelo de negócio de um negócio inclusivo, segundo o conceito de ecossistemas, (iii) comparar nos estudos de caso de cada país os fatores que contribuem, de forma positiva e negativa, na implementação do negócio inclusivo.

\subsection{Estrutura do trabalho}

Procurando elaborar e desenvolver esta reflexão, foram desenvolvidos cinco capítulos:

- Capítulo 1 - delimitação do problema de pesquisa, objetivos e justificativa

- Capítulo 2 - contextualização e evolução dos conceitos teóricos

\footnotetext{
${ }^{2}$ Para maiores detalhes sobre o método e resultados neste levantamento, ver Anexo 1.
} 
- Capítulo 3 - procedimentos metodológicos para realização da pesquisa

- Capítulo 4 - análise comparativa de um modelo de negócio aplicado a três diferentes países.

- Capítulo 5 - considerações finais e recomendações para futuras pesquisas. 


\section{REFERENCIAL TEÓRICO}

\subsection{Ecossistema Orientado para o Mercado dos Negócios Inclusivos}

O conceito de ecossistema é utilizado com diferentes abordagens na área de gestão de organizações. Segundo Reficco e Vernis (2010), a noção vem do estudo do ambiente onde a organização compete, analisando dinâmicas como a evolução das populações, conceito que surge a partir da ecologia organizacional ${ }^{3}$.

Para Moore (1996 apud REFICCO; VERNIS, 2010), um ecossistema é uma comunidade econômica sustentada por uma base de organizações que interagem em torno da produção de bens e serviços.

Prahalad (2008, p.72) utiliza o conceito de ecossistema orientado para o mercado como sendo:

uma estrutura que permite ao setor privado e a vários outros participantes sociais, muitas vezes com tradições e motivações diferentes, e de tamanhos e áreas de influência diferentes, agir juntos e criar riqueza em uma relação simbiótica. Esse ecossistema consiste de uma ampla variedade de instituições coexistindo e complementando-se. Usamos o conceito do ecossistema porque cada um de seus participantes tem um papel a representar. São dependentes uns dos outros. O sistema se adapta e evolui e pode ser persistente e flexível. Mesmo havendo distorções na margem, o sistema é orientado para um equilíbrio dinâmico. (PRAHALAD 2008, p.72).

O autor conceitua os componentes do ecossistema utilizando a ilustração a seguir.

Figura 1 - Componentes do ecossistema baseado em mercado

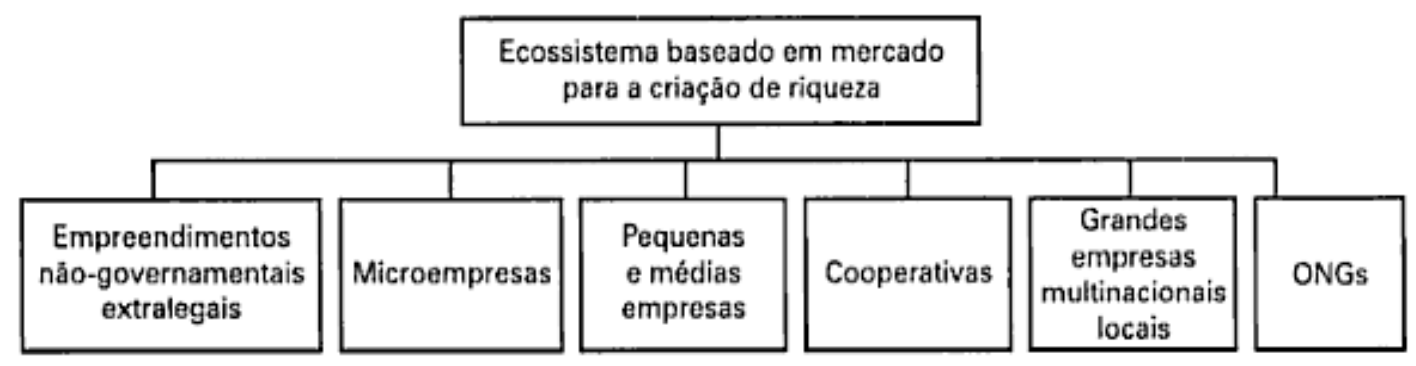

Fonte: PRAHALAD, 2008, p.73.

3 A ecologia social foi primeiro discutida por Glenn R. Carroll, “Organizational Ecology” Annual Review of Sociology” em 1984 e seguida por Michael T. Hannan e John Freeman "Organizational Ecology, Cambridge, Mass: Harvard University Press"em 1989. 
Ele mostra diversas organizações formais ou informais coexistindo e formando o chamado ecossistema baseado em mercado e gerador de riqueza. Os componentes desse ecossistema seriam: "empreendimentos extralegais", isto é, iniciativas advindas da economia informal, microempresas, pequenas e médias empresas, cooperativas, grandes empresas multinacionais locais e Organizações Não Governamentais (ONGs).

Segundo Reficco e Vernis (2010), é um conceito que vai além dos marcos tradicional como a cadeia de valor, cadeia de valor estendida ou sistemas de valor de Michael Porter (1985). O conceito abordado pelo autor soma à definiç̧ão de Prahalad (2008), a existência de uma organização central que lidera o negócio inclusivo orientado para o mercado.

Assim, ao analisar as características de um negócio inclusivo, devem ser observados aspectos da cadeia de valor da organização pivô, bem como a interação com outros atores do ecossistema, representada pela figura a seguir (REFICCO; VERNIS, 2010, p.104).

Figura 2 - Ecossistema organizacional e seus componentes

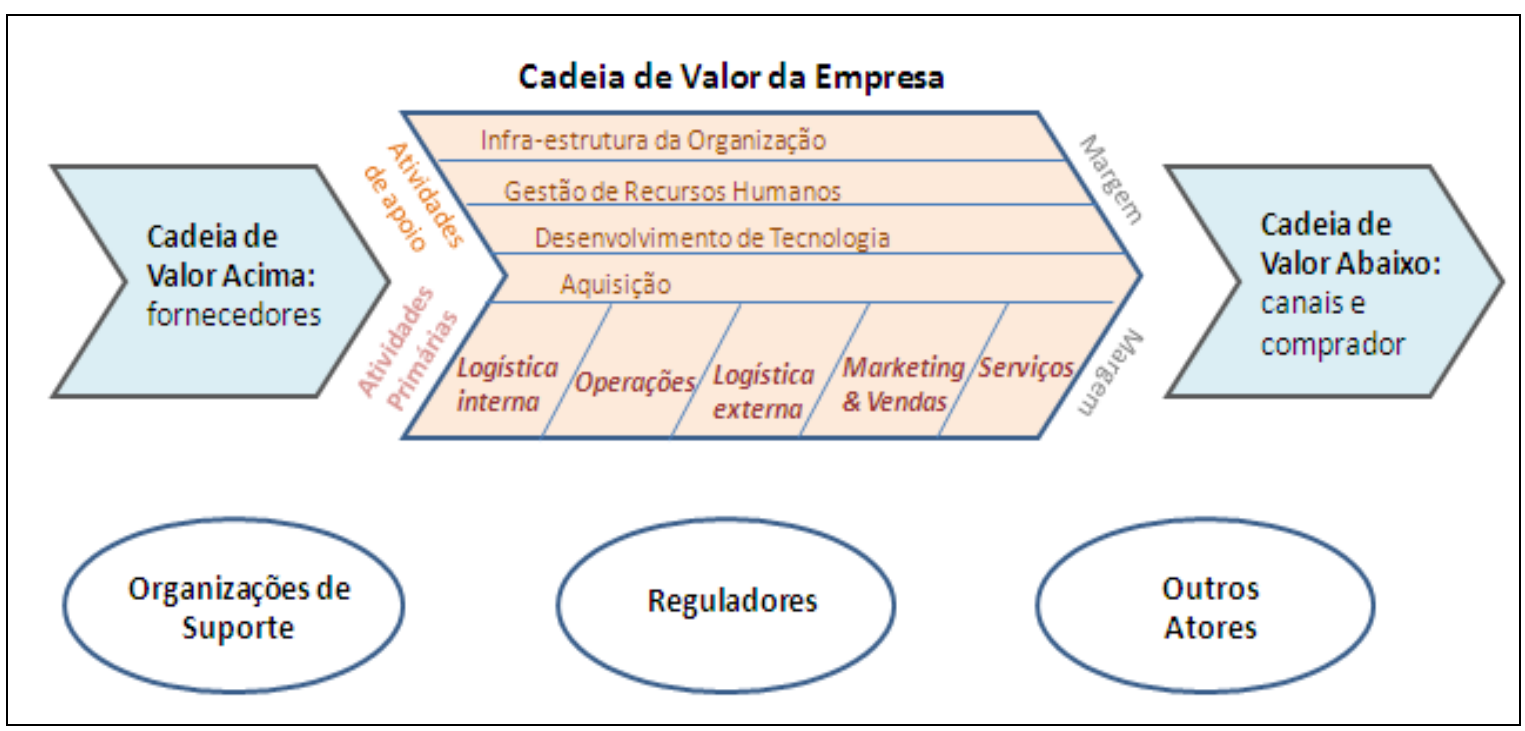

Fonte: REFICCO; VERNIS, 2010, p.104.

O estudo do ecossistema deve levar em conta as seguintes dimensões relativas ao comprometimento das iniciativas de negócios inclusivos com seu ecossistema, abordadas por Reficco e Vernis (2010, p. 106 - 112): 
Relações com stakeholders: o nível de interação com stakeholders (internos e externos) deve fazer parte do estudo do ecossistema de uma organização. Os autores afirmam que questões como relações com comunidades devem deixar de ser periféricas e deveriam entrar na pauta de discussão estratégica das organizações.

Redução das incertezas possibilitando a entrada de investimentos: deve ser observada a análise do nível de engajamento entre os membros do ecossistema de modo que a construção dos laços possibilite menor risco para investidores. Os autores sugerem engajar membros do ecossistema para reduzir as incertezas com a construção de ligações efetivas entre a oferta e a demanda. Um exemplo disso é desenvolver um novo modelo de negócio que permita o livre fluxo de informação e recurso, coordenando decisões de investimentos e permitindo aos parceiros produzirem exatamente o que o mercado demanda.

Redução dos custos de transação: observar como a organização consegue aumentar sua margem de ganho, garantindo o acesso dos produtos e serviços à população de baixa renda. A maior parte das iniciativas que trabalham com setores de baixa renda operam com margens pequenas, o que significa que elas precisam de volumes maiores para atingir a rentabilidade. A relação direta com consumidores pode ser complexa, para tanto, os autores sugerem reduzir o número de interlocutores e operar em colaboração com organizações que já atuam na área, por exemplo, parcerias com distribuidores.

Utilizar a infra-estrutura social já existente: deve-se levar em conta na análise, o ganho de escala e de escopo pelas iniciativas de negócios inclusivos. As organizações podem capitalizar sua rica carteira de relações e de confiança construída ao longo dos anos com os setores de baixa renda como um ativo produtivo que permite gerar recursos econômicos enquanto perseguem sua missão. Depois de desenvolvida uma rede sólida para ajudar os indivíduos vulneráveis com um projeto, pode-se desenvolver outro projeto do mesmo tipo e ganhar em "economia de escala". Assim, à medida que a produção aumenta, o custo por unidade tende a cair. A mesma rede pode ser utilizada para lançar outros produtos ou atividades complementares, o que seria o ganho de “economia de escopo". 
Capacidade de realizar mudanças estruturais no ambiente: um dos grandes objetivos das organizações deve ser o alto impacto das iniciativas. Trabalhando em parceria com outros membros da comunidade econômica, as organizações podem aumentar o escopo e perseguir as metas que seriam dificilmente atingidas se realizadas individualmente. Assim, quando essa lógica é levada ao extremo, a organização é capaz de modificar a estrutura do ambiente no qual operam os atores do ecossistema, porém não são suficientes e devem sempre ser levado em consideração o contexto, bem como os diversos atores como Estado e a própria sociedade civil.

\subsection{Fatores Críticos de Sucesso}

Conforme abordado anteriormente, a teoria de Fatores Críticos de Sucesso (FCS) será utilizada neste trabalho, com o objetivo de dar sustentação ao estudo dos fatores que contribuem positivamente e negativamente para o atingimento dos objetivos essenciais de um negócio inclusivo.

Os FCS são, para qualquer empresa, o número limitado de áreas nas quais os resultados, caso sejam satisfatórios, irão assegurar um desempenho competitivo de sucesso para a organização. De forma mais simples, são "apenas poucas áreas chave onde 'as coisas devem ir bem' para que o negócio possa prosperar" 4 (ROCKART, 1979; BOYNTON, ZMUND, 1984).

Segundo Drucker (1973), quando identificados, esses atributos podem ser aplicados aos negócios em sua fase de implementação e podem reduzir a grande probabilidade dessas iniciativas falharem. Ainda, segundo o autor, os mesmos fatores aplicados a negócios prósperos podem aumentar o desempenho organizacional ${ }^{5}$.

\footnotetext{
4"They are the few keys areas where things must go right for the business flourish."( ROCKART, 1979, p.85); "those few things that must go well to insure the success of an organization" (BOYNTON, ZMUND, 1984)

${ }^{5}$ If these necessary attributes can be identified in a general population of businesses then their informed application to embryonic businesses might reduce the (high) probability that these endeavors will fail. These same factors applied to thriving businesses may enable high organizational performance (DRUCKER, 1973).
} 
Leideker e Bruno (1984, p.24) complementam afirmando ainda que:

Fatores Críticos de Sucesso (FCS) são aquelas características, condições ou variáveis que quando adequadamente sustentadas, mantidas ou gerenciadas podem ter um impacto significativo sobre o sucesso de uma empresa que concorre em um determinado setor. Os FCS podem ser uma característica como, por exemplo, a vantagem de preço, mas também podem ser uma condição como, por exemplo, a estrutura de capital ou vantagem de mix de clientes, ou uma característica estrutural da indústria, tais como integração vertical. ${ }^{6}$

De acordo com Aaker (2005), os FCS são qualquer ativo competitivo ou competência que é necessária para vencer no mercado, seja uma vantagem competitiva estratégica, ou meramente um ponto de paridade com o concorrente. $\mathrm{O}$ autor reforça o fato de que $\mathrm{o}$ ambiente de negócios se altera ao longo do tempo e que, portanto, os FCS também deverão se alterar. Um exemplo disto, são empresas que estabelecem um forte posicionamento nos estágios iniciais de suas operações, mas perdem espaço ao longo do tempo (AAKER, 2005).

O tamanho e proporção de uma empresa também fazem com que os FCS se alterem. Assim, os FCS são estudados para diversos tipos e tamanhos de organizações. Keats e Bracker (1988) desenvolveram um modelo para pequenas empresas que tem como base o ecossistema e o perfil do empreendedor. Sridhar e Nagabhushanam (2008) propuseram um modelo para Organizações Não Governamentais com base tanto em aspectos tangíveis ("hard factors": estrutura, tamanho, objetivos de curto prazo, fundos, profissionalismo, suporte governamental, etc.) e intangíveis ("soft factors": visão, voluntariado, espaço, cultura, liderança, sucessão, valor agregado para sociedade, etc.) assim como a fase da organização (implementação, sobrevivência e consolidação).

Assim, no presente estudo, serão analisados os Fatores Críticos de Sucesso de um negócio inclusivo, observando tanto os aspectos positivos, como também aqueles que geram aprendizados e desafiam a organização na sua fase de implementação.

6 "Critical Success Factors (CSF) are those characteristics, conditions, or variables that when properly sustained, maintained, or managed can have a significant impact on the success of a firm competing in a particular industry. A CSF can be a characteristic such as price advantage it can also be a condition such as capital structure or advantageous customer mix; or an industry structural characteristic such as vertical integration." (LEIDEKER; BRUNO, 1984, p.24) 


\subsection{Contexto Histórico: Negócios Inclusivos}

O Banco Mundial estima que em 2005, 1,4 bilhões de pessoas em países em desenvolvimento ainda viviam com menos de $\$ 1,25$ dólares por dia (BANCO MUNDIAL, 2008). O mais recente dado da Organização Mundial de Saúde, OMS, (2010) mostra que a falta de acesso a água potável atinge $13 \%$ da população mundial, sendo 884 milhões de habitantes que vivem diariamente com fontes precárias para o suprimento de água e 2,3 bilhões de pessoas que não dispõem de nenhum tipo de saneamento básico. Somados a esses problemas, resolver questões como a desigualdade de distribuição de renda, os baixos índices de desenvolvimento humano e a destruição de florestas são apenas alguns dos desafios de governos, órgãos internacionais e iniciativas humanitárias entre outras organizações da sociedade civil em países em desenvolvimento.

A condição de pobreza está associada à exclusão social dos indivíduos caracterizada pela marginalidade econômica, social e/ou política. Segundo Sen (2000), a pobreza não deve ser entendida meramente como sendo baixo nível de renda, mas sim como privação de capacidades básicas. Essa abordagem defende que existem outros fatores além do nível de renda que ocasionam a privação de capacidades, como a falta de políticas de desenvolvimento social, difícil acesso à educação básica, escassa prestação de serviços de saúde, etc. Sendo assim, a pobreza estaria associada ao grupo das minorias como as pessoas com deficiência, as minorias étnicas, indivíduos com baixa qualificação, população de rua, jovens em áreas com grande vulnerabilidade social, idosos.

Apesar dessa visão, durante muito tempo no Brasil, principalmente entre as décadas de 1960 e 1970, a pobreza poderia ser combatida por uma simples equação. Acreditava-se na promessa do desenvolvimento acelerado, isto é, uma política econômica com meta de crescimento da produção industrial e de infra-estrutura com participação ativa do Estado, e que traria riqueza econômica e o bônus de um desenvolvimento social. Estudiosos pautavam sua visão em um "crescimento urbano-industrial focado em metas macro-econômicas, muitas vezes desvinculadas das necessidades sociais e ambientais específicas de cada localidade e de sua população.” (FISCHER et al, 2004, p.2). 
O discurso sobre o desenvolvimento econômico e da abundância de geração de riqueza e desenvolvimento social foi em certa medida uma promessa não cumprida (REFICCO et al, 2006). Grande parte dos países pobres ou em desenvolvimento enfrenta problemas como má distribuição de renda, crise de endividamento, opressão e violência.

Urbanização acelerada, migrações desestruturantes, exploração irracional de recursos naturais e, principalmente, os baixos padrões de vida de amplas camadas da população, evidenciaram que o modelo era insuficiente para criar equilíbrio econômico e justiça social. (FISCHER et al, 2004, p.2).

No contexto da América Latina, há o agravante da desconfiança quanto à boa gestão dos governos. Políticas sociais praticamente inexistentes, fraqueza nas relações internacionais de poder e escândalos de corrupção caracterizam o quadro político de muitos destes países.

Nos anos 80, a conjuntura recessiva da economia internacional aprofundou ainda mais a desigualdade social dos países da América Latina (FISCHER et al, 2004) e o aparecimento de organizações sem fins lucrativas e não governamentais marcam o final desta década.

Segundo Salamon (1998, p.7):

O crescimento do Terceiro Setor decorre de várias pressões, demandas e necessidades advindas das pessoas, como cidadãos, das instituições e até dos próprios governos. Ele reflete um conjunto nítido de mudanças sociais e tecnológicas, aliado a contínua crise de confiança na capacidade do Estado. Mudanças históricas de longo alcance abriram o caminho para que as instituições alternativas possam atender melhor às necessidades humanas. (SALAMON, 1998, p.7).

Levando em conta a perspectiva de Sen (2000), na qual a pobreza é a privação da liberdade do indivíduo, pode-se dizer que o surgimento dessas organizações sem fins lucrativos são formas de gerar desenvolvimento social, expandindo a educação básica, prestando serviços de saúde, proporcionando moradia, além da geração de renda. Assim, instituições que visam atender as necessidades básicas do ser humano, como as organizações do chamado Terceiro Setor, proporcionariam a criação de instrumentos para a redução da pobreza.

No âmbito corporativo, acontecimentos marcantes em grandes empresas marcaram os anos 90. Novos padrões foram criados e fatos que eram aceitáveis em anos anteriores 
passaram a ser repudiados. Para ilustrar, situações como a de um dos fornecedores da Nike que ao fazer uso de mão de obra infantil colocou a empresa em difícil situação perante a sociedade, fez com que muitas empresas fossem pressionadas a se responsabilizar por sua cadeia produtiva, fato que não era usual até então. Escândalos de corrupção em empresas privadas também começam a ser alvo de crítica nesta época, como foi o caso da Enron, em que a falta de transparência e a deflagração das fraudes contábeis desarmonizou o ambiente das grandes corporações.

Como reação a esse e outros acontecimentos semelhantes, durante os primeiros anos de 2000, importantes empresas passam a adotar políticas de governança corporativa. Em alguns países como os Estados Unidos, surgem novas exigências de regulação como a lei americana Sarbanes-Oxley de 2002. Ao mesmo tempo, é possível observar um aumento da pressão feita por parte dos consumidores com relação à transparência das companhias no âmbito social e ambiental. O crescente interesse socioambiental das empresas parece, então, estar associado às novas exigências de competitividade de mercado. Ainda, muitas organizações passam a atender de maneira especial às necessidades das comunidades das quais pertencem. Cresce o número de organizações socialmente responsáveis que, cada vez mais, aproximam-se dos stakeholders direta ou indiretamente envolvidos.

A partir de então, empresas e principalmente as organizações do Terceiro Setor começam a contribuir de forma sistemática com soluções a certos problemas sociais adotando um modelo de desenvolvimento social efetivo, participativo e de longo prazo.

Assim, apesar das diferentes tradições e realidades, é possível observar um movimento em torno da instauração de governança corporativa com propostas de desenvolvimento de longo prazo envolvendo stakeholders diretos e indiretos. Savitz e Weber (2007, p.229) corroboram e argumentam que:

A antiga visão dos negócios, segundo a qual o desempenho financeiro era o único critério de avaliação das empresas, está sendo considerada, em curto prazo, inadequada para atender às demandas de um mundo interdependente e, em longo prazo, fator determinante para o insucesso.

Abramovay (BASTOS et al, 2006), mostra como os mercados, para se inserirem na vida 
social, dependem totalmente de aspectos externos como: o Estado, as organizações, as leis, os costumes. Assim, os mercados devem responder a preceitos de natureza éticonormativa, o que significa dizer que as empresas, principalmente as de grande porte, passam a atuar com estratégias sociais e ambientais como forma de criar proteção às pressões sociais e regulatórias, pois elas têm o poder de alterar profundamente as relações socioeconômicas e culturais de seu entorno e, por esta razão, adquirem maior visibilidade, sendo alvo privilegiado de movimentos sociais, ambientalistas e de regulação ambiental.

Por outro lado, Prahalad (2005) aponta que, os mais de quatro bilhões de pessoas vivendo com menos de US\$ 2 por dia são uma oportunidade de mercado e propõe aos provedores de produtos e serviços, incluindo as companhias multinacionais, desenvolverem novos modelos de negócios, considerando as famílias de baixa renda como um futuro segmento consumidor importante.

Ao mesmo tempo, o aumento do número de organizações de terceiro setor faz com que haja entre elas uma "concorrência" em relação às doações. Portanto, algumas das organizações sem fins lucrativos começam a diversificar suas receitas deixando de depender apenas de doações para sua sobrevivência. Uma nova onda de empreendedorismo social surge.

Segundo Dees (1998, p.1):

A nova designação é importante porque implica uma diluição das fronteiras entre setores. Para além de atividades inovadoras sem fins lucrativos, o empreendedorismo social pode incluir atividades lucrativas com objetivos sociais, como bancos de desenvolvimento comunitário, e organizações híbridas que combinam elementos lucrativos e não-lucrativos, como os abrigos para os sem-abrigo que iniciam atividades lucrativas para formar e dar trabalho aos seus utilizadores.

Segundo Young (2008), apesar da ambiguidade e diversidade dos termos, este tipo de empreendimento é visto como algo importante e distinto da forma clássica e tradicional de fazer negócios.

Reficco et al (2006) concluem que as diferentes formas de organização com finalidade social, desde as iniciativas sociais dentro de empresas até empreendimentos sociais 
autônomos, vêm ganhando destaque e são transformações de extrema importância. Entretanto, deve-se levar em conta as diferenças existentes entre os empreendimentos sociais e os negócios inclusivos.

Os negócios inclusivos nascem dentro das premissas de empreendedorismo social. Segundo Yunus (2007), negócios sociais e empreendedorismo social não têm o mesmo significado. Para o autor, todos aqueles que criam e implementam um negócio social são empreendedores sociais, mas nem todos os empreendedores sociais estão engajados em negócios sociais (YUNUS, 2007). Em outras palavras, o autor afirma que o negócio social está classificado como um subconjunto de empreendedorismo social. Empreendedorismo social seria portanto, um termo mais amplo, definido pelo autor como, qualquer iniciativa inovadora que é criada com objetivo social.

Historicamente, a terminologia das empresas sociais, veio à tona internacionalmente a partir de duas tradições acadêmicas diferentes de conceber terceiro setor (REFICCO et al 2006). As tradições a que o autor se refere são: a européia, com influência do associativismo, cooperativismo e com forte presença do Estado; e a norte-americana centrada na figura de um empreendedor e com grande influência da filantropia praticada por empresas privadas.

$\mathrm{Na}$ seqüência, serão apresentadas essas duas principais correntes, bem como uma terceira que vem surgindo em países emergentes com uma abordagem que privilegia a inclusão da população de baixa renda. Serão levantadas as características das empresas sociais, negócios inclusivos e negócios sociais, aqui tratadas como negócios inclusivos e suas distintas formas de entendimento.

\subsection{Evolução do conceito teórico de negócios inclusivos}

Como anteriormente citado, há diferenças expressivas entre os conceitos e práticas de empreendimentos sociais em diferentes regiões, especialmente porque a motivação de seu aparecimento, a estrutura organizacional adotada, os objetivos finais, entre outras características específicas são condicionadas pelo contexto social, político e econômico do país em que essas iniciativas se inserem (REFICCO et al, 2006). 
Esses empreendimentos sociais aparecem com denominações diferentes, mas muitas vezes representam realidades muito parecidas: negócios comunitários, projetos sociais, economia solidária e cooperativas são alguns dos termos usados.

Recentemente, novos termos como empresas sociais, negócios inclusivos e negócios sociais têm surgido. Segundo Reficco et al (2006), embora a existência de empresas sociais não seja um fenômeno novo, sua identificação como tal tem apenas alguns anos. Por ainda não se ter clareza nas definições desses novos tipos de empreendimentos, a compreensão dos diferentes enfoques da discussão nas diversas realidades se faz necessária. Com objetivo de aprofundar a discussão sobre o tema, serão apresentadas as três principais perspectivas dos negócios inclusivos, ou seja: a visão européia, a norteamericana e a dos países emergentes.

Na seqüência das perspectivas, será apresentado um retrato do que se encontra hoje na literatura relacionada com o tema dos negócios inclusivos. A partir de um amplo levantamento bibliográfico, buscou-se classificar os trabalhos nas seguintes dimensões: conceitual, gestão e impacto. Não se propõe fazer uma análise exaustiva de cada um dos trabalhos, mas sim, em linhas gerais, traçar a direção em que as discussões atuais sobre o tema estão caminhando. Esta discussão, muito mais descritiva, terá como papel auxiliar na elaboração do modelo teórico a ser utilizado no presente estudo.

\subsubsection{Análise das perspectivas}

Primeiramente, será analisada a perspectiva européia de empresa inclusiva, que, segundo Reficco (2006), tem raiz na "economia social" francesa, que inclui cooperativas, sociedades mútuas e associações, e que, posteriormente, se tornou a base da economia solidária no Brasil (SINGER, 2002).

A aproximação com iniciativas da Economia Popular Solidária é bastante evidente na proposta dos Negócios Inclusivos, no entanto, diferencia-se dela porque não se circunscreve apenas a empreendimentos cooperativistas ou autogestionários. Ou seja, pode-se dizer que Negócios Inclusivos abrangem a Economia Popular Solidária, mas não o contrário (TEODOSIO, 2011). 
Logo após, a visão norte-americana, entendida basicamente como organizações privadas dedicadas a soluções de problemas sociais. Em seguida, será analisada a abordagem dos países emergentes, trazendo conceitos dos negócios sociais de Yunus (2007) e de negócios inclusivos, explorado pela Social Enterprise Knowledge Network (SEKN) ${ }^{7}$, na qual a população de baixa renda está muitas vezes na função de produtores e não simplesmente consumidores.

\subsubsection{1 - Perspectiva Européia}

O processo de formação das empresas sociais na Europa teve como motivação inicial a necessidade de descobrir novas maneiras de controlar os custos do setor público com as causas sociais, e trabalhar as populações marginalizadas desempregadas (BORZAGA \& DEFOURNY, 2001 apud YOUNG, 2009, p. 33).

As empresas sociais na Europa estão voltadas para o mercado, mas sem perder o alvo social e, sobretudo, colaborando com a administração pública. Elas apresentam, como principais características, a prestação de serviços públicos, e, em sua maioria, o fato de serem financiadas por recursos governamentais.

Segundo Young (2007, p.175), a empresa social é definida pelo "engajamento de várias formas de organizações não governamentais, em atividades do serviço público”. Assim, o termo é usado para definir algumas atividades econômicas com objetivos sociais, altamente envolvidas em prover serviços para a administração pública, principalmente no campo de inclusão de pessoas em situação de necessidade.

Segundo Tavaglini (2008), na Europa é possível agrupar três categorias de atuação das empresas sociais: (i) empresas de integração ao trabalho, conhecidas como Work

7 SEKN é uma rede fundada em 2001 com o objetivo de avançar na fronteira do conhecimento e prática de empresa social. As universidades ibero-americanas que integram o SEKN são EGADE Business School, EGADE (México); ESADE Business School, ESADE (España); Harvard Business School (Estados Unidos); Instituto de Estudios Superiores de Administración, IESA (Venezuela); Instituto Centroamericano de Administración de Empresas, INCAE (Costa Rica); Pontificia Universidad Católica de Chile, PUCCh (Chile); Universidad de los Andes, Uniandes (Colombia); Universidad del Pacífico, UP (Perú); Universidad de San Andres, UdeSA (Argentina); Universidade de Sao Paulo, FEA/USP (Brasil). 
Integration Social Enterprise (WISE); (ii) empresas cujo objetivo social primordial é produzir produtos e serviços com alvo social ou conduzido por interesse coletivo (iii) empresas que favorecem o desenvolvimento social e econômico local pela promoção de participação de cidadãos e governo local nas atividades.

De acordo com a definição de pesquisadores da rede Emergence of Social Enterprise in Europe (EMES, 2010), as empresas sociais são “organizações com o objetivo explícito de beneficiar a comunidade, iniciadas por um grupo de cidadãos, e nas quais o interesse material dos investidores capitalistas é sujeito a limites. Eles valorizam muito a independência da organização e aceitam o risco econômico relacionado com as atividades socioeconômicas em curso" ${ }^{8}$.

Borzaga e Galera (2009, p.214) afirmam que: “em empresas sociais, os lucros adquiridos são reinvestidos prioritariamente na organização e usados para dar suporte ao seu crescimento." 9

Assim, essas empresas promovem as condições de vida de uma comunidade ou um determinado grupo por meio de uma ou mais atividades econômicas, envolvendo riscos, sem, no entanto, distribuir resultados financeiros.

Segundo Travaglini et al (2008), não há nenhum modelo legal único utilizado para regular empresa social. Para o autor, fazem parte do grupo de empresas sociais, as companhias limitadas com garantia, indústrias, sociedade de previdência e companhias limitadas por ações.

Corroborando essa visão, a Organization for Economic Co-operation and Development $(\mathrm{OECD}, 1999)^{10}$ define empresas sociais como sendo organizações que assumem

\footnotetext{
8 "Organisations with an explicit aim to benefit the community, initiated by a group of citizens and in which the material interest of capital investors is subject to limits. They place a high value on their independence and on economic risk-taking related to ongoing socio-economic activity." (EMES, 2010)

9 "In social enterprises, profits gained are mainly reinvested in the organization and used to support its growth. ”(BORZAGA;GALERA, 2009, p.214)

10 Originou-se em 1960, com objetivo de juntar forças para criar uma organização voltada para o desenvolvimento global, hoje conta com 34 países membros. (OECD, 2011)
} 
diferentes formas legais entre os países pertencentes da OECD e que buscam metas sociais e econômicas com espírito empreendedor e enfatiza que o propósito principal não deve ser a maximização do lucro, mas sim a consecução de metas econômicas e sociais, nas quais tenha a capacidade de trazer soluções inovadoras para problemas de exclusão social e desemprego.

Apesar de muitos autores não ressaltarem a necessidade de diferenciação com relação à constituição das empresas sociais, por princípio elas têm objetivos originais sociais nas quais o lucro é reinvestido nos propósitos do negócio ou na comunidade, ao invés de ser dirigido para maximizar o lucro dos acionistas e donos. Assim, seria possível dizer que uma empresa social não é definida em termos jurídicos, mas sim por sua natureza de atividade.

Para a Social Enterprise Coaligtion (2011),

as empresas sociais são negócios comerciais com propósitos sociais e ambientais. Muitos negócios comerciais poderiam ser considerados como tendo objetivos sociais, mas as empresas sociais são distintas, pois o propósito social e ambiental deles é absolutamente central àquilo que ela faz e os lucros são reinvestidos para dar suporte e levar a diante a missão deles para uma mudança positiva ${ }^{11}$.

Uma empresa social, portanto, se diferencia de uma empresa tradicional por sua natureza de atividade, que deve ser centrada em propósitos sociais e ambientais, além do lucro ser apenas uma forma de suporte para que a missão social seja viabilizada.

Uma definição amplamente utilizada por organizações na Europa e criada pelo Departamento de Comércio e da Indústria do Governo do Reino Unido (GOVERNO DO REINO UNIDO, 2001) afirma que:

as empresas sociais são negócios com objetivos sociais primordiais nos quais o a receita gerada é reinvestida principalmente para os propósitos do negócio ou na comunidade, ao invés de serem destinados à necessidade de maximização de lucro dos acionistas e proprietários. ${ }^{12}$

11 "Social enterprises are businesses trading for social and environmental purposes. Many commercial businesses would consider themselves to have social objectives, but social enterprises are distinctive because their social and/or environmental purpose is absolutely central to what they do - their profits are reinvested to sustain and further their mission for positive change."(SOCIAL ENTERPRISE COALIGTION, 2011)

12 "Social Enterprises are businesses with primarily social objectives whose surpluses are principally reinvested for that purpose in the business or in the community, rather than being driven by the need to maximise profit for shareholders and owners. "(GOVERNO DO REINO UNIDO,2001) 
Segundo Travaglini et al (2008), as empresas sociais existentes possuem as seguintes características e é importante compreendê-las: (i) orientação para negócios - elas estão diretamente envolvidas na fabricação de produtos e na prestação de serviços para o mercado; (ii) orientação para causa social - elas têm causas sociais ou ambientais explicitas tais como a criação de emprego, treinamento, etc., e seus lucros são reinvestidos para atingir seus objetivos sociais; (iii) muitas empresas sociais também são caracterizada pela propriedade social (social ownership). Elas são organizações autônomas, sua governança e estrutura de propriedade são baseadas na participação direta de grupos de stakeholders (isto é, empregados, usuários, clientes, grupo de comunidade local e investidores sociais), ou de administradores ou diretores que controlam a empresa com o objetivo de atender um grupo vasto de stakeholders. Eles são transparentes para com seus stakeholders e para com a comunidade por meio do impacto social, ambiental e econômico que trazem. Quanto à distribuição de lucros, o autor aqui afirma que algumas dessas empresas acabam por distribuir os lucros como cotas para os stakeholders, ou, ainda, usam-nos para o benefício da comunidade, mas sempre com propósito de promover a integração econômica e social de pessoas não favorecidas.

Diferentemente de outras definições de autores e organizações citadas anteriormente, Travaglini et al (2008) explicita que pode haver de fato a existência de distribuição de lucros para stakeholders (empregados, usuários, clientes, grupo de comunidade local e investidores sociais), mas, como os outros autores, ele reforça que isto ocorre apenas como propósito de inclusão social.

O modelo de governança é também um dos pontos de maior relevância na definição das empresas sociais européias. Esse aspecto decorre das tradições européias de associativismo. Segundo Graziano (1993), o pluralismo moderno é o pluralismo da associação voluntária baseada na livre participação de seus membros, e a existência de tais grupos é uma conseqüência da Europa pós-revolucionária (Revolução Francesa), mais exatamente uma reação à concepção liberal de Estado e a seu princípio fundador, a soberania nacional "une et indivisible". Assim, a lógica de tomada de decisão no modelo europeu de negócios inclusivos é o processo participativo e transparente como prérequisito para sua caracterização. Além disso, também pela questão de tradição e 
cultura, os negócios inclusivos na Europa, engajam-se na promoção de serviços sociais e serviços de integração para o trabalho para grupos desfavorecidos e comunidades, seja em áreas urbanas ou rurais. Ainda, elas prestam serviços para a comunidade principalmente na área educacional, cultural e ambiental.

Assim, é possível observar uma tendência no modelo europeu de valorização do coletivo, participação na tomada de decisão de todos stakeholders envolvidos e ainda a transparência na gestão. Essa dimensão coletiva e participativa faria com que houvesse "redução de comportamentos oportunistas isolados gerando uma estrutura de governança” (BORGAZA, GALERA, 2009, p.213). Assim, no modelo europeu, além das organizações possuírem um propósito social, elas devem ter a atribuição de direitos de propriedade e poder de controle de outras partes interessadas que não os investidores, acoplado a um modelo de governança aberta e participativa (BORGAZA, GALERA, 2009).

\subsubsection{2 - Perspectiva Norte-Americana}

O termo empresa social começou a ser empregado amplamente nos Estados Unidos no momento em que as organizações não-governamentais começaram a expandir suas atividades comerciais. Este movimento foi impulsionado predominantemente pela escassez de recursos gerada pela retração do financiamento estatal, iniciado no fim dos anos 1970 (KERLIN, 2006, p.251).

Young (2007, p. 175) afirma que nesse contexto, a empresa social "vem para descrever a realização de empreendimentos comerciais e o envolvimento com corporações de negócios, por meio de organizações sem fins lucrativos através de um amplo espectro de atividades ligadas ao serviço público." 13

As empresas podem seguir uma estratégia de receita participando do mercado como as empresas tradicionais ou ainda, ter uma estratégia de inovação social, encontrando

\footnotetext{
13، Has come to describe the undertaking of commercial ventures and engagement with business corporations by nonprofit organizations across a broad spectrum of public service-related activity"(YOUNG, 2007, p.175)
} 
soluções criativas para se dirigirem aos problemas sociais.

Segundo Young (2009, p.35), a empresa social pode ser vista por várias lentes disciplinares diferentes e apresenta uma seqüência de possibilidades desde iniciativas ligadas à responsabilidade social empresarial ou marketing de grandes corporações, até instituições criadas exclusivamente para gerar valor social e são elas: (i) filantropia corporativa: uma organização com fins lucrativos que dedica um percentual de seus recursos para programas sociais, como parte de sua estratégia competitiva; (ii) empresa com fim social: organização que opera no mercado de forma a concretizar sua missão social de forma mais eficaz; (iii) híbrido: organização com o duplo desafio de levar retorno monetário a seus stakeholders e atingir objetivos sociais definidos; (iv) projeto de geração de recursos: uma atividade voltada exclusivamente para gerar receita para a organização; (v) projeto de finalidade social: atividade de uma organização destinada exclusivamente a endereçar a uma missão social ou objetivos sociais ou selecionados; (vi) projeto híbrido: atividade de uma organização direcionada tanto para produção de receita quanto para contribuir para a missão ou objetivos sociais da organização.

Apesar de existir um grupo de profissionais e de políticos que vêem as empresas sociais como uma nova instituição, um tipo de empresa de economia mista, híbrida, na qual combina geração de lucro com atingimento de metas sociais (KERLIN, 2006), nos Estados Unidos, as empresas sociais ainda podem ter diferentes formas legais, incluindo sociedades anônimas, corporações, companhias limitadas e organizações sem fins lucrativos.

Assim, sob a perspectiva norte-americana, o conceito de empresa social inclui qualquer ação empreendedora de mercado, independente de distribuir lucro e que não faça qualquer restrição a um modelo de governança, mas que, sobretudo tenha impacto social com sua ação comercial.

Os diferentes limites existentes entre organizações sem fins lucrativos e empresas tradicionais podem ser encontrados juntos ou de forma alternada em uma mesma empresa social.

Young (2009, p.22) afirma que: 
formas legais (organizações com fins lucrativos, sem fins lucrativos e empresas híbridas) que as empresas sociais podem assumir e as práticas relacionadas ao negócio que elas podem empregar - assim como pesquisa de mercado, precificação, colaboração, parcerias institucionais - estão correlacionadas com as identidades organizacionais associadas às empresas sociais de diferentes tipos.

Apesar das ambigüidades e da dificuldade em delimitar o conceito, é possível observar a existência de novos parâmetros que definem essas empresas sociais como sendo uma alternativa que tem características vindas tanto de organizações sem fins lucrativos quanto das empresas tradicionais.

Segundo Boik (2011, p.13), nos Estados Unidos existem dois tipos de iniciativas que parecem estar buscando equilibrar a estrutura de uma organização corporativa com valores sociais e ambientais e são elas: Low-Profit, Limited Liability Company (L3C) e Befenit Corporation.

Em 2008, foi aprovada nos Estados Unidos uma nova forma jurídica de organização, a L3C, que é uma empresa híbrida entre sem fins lucrativos e uma empresa por lucro. Essa seria um tipo de empresa limitada designada para atrair investimentos e capital filantrópicos para prover benefício social. A nova forma regulamentada de organização coloca como principal objetivo o fator social e em segundo plano a preocupação com o lucro, entretanto, existe a possibilidade para distribuir lucros, depois dos impostos, aos proprietários ou investidores. Por ser muito recente, a L3C até final de 2010 poderia ser criada em apenas alguns estados americanos.

Tomando como base o exemplo da regulamentação L3C, é possível observar que a abordagem americana foge da dependência do financiador público estatal para a existência das iniciativas de negócios sociais e ressalta a figura do proprietário ou empreendedor, isto é, o indivíduo como responsável pela geração do impacto social positivo através de um negócio comercial, concorrendo no mercado como qualquer outra empresa por lucros.

A Benefit Corporation, assim como a L3C, é uma forma estatutária de corporação que foi recentemente adotada nos Estados Unidos (Maryland and Vermont). Diferentemente da L3C, ela é uma corporação criada para prover um benefício público geral, que é 
definido como um impacto positivo e material na sociedade e no meio ambiente, medido por um parâmetro externo, por meio de atividades que promovam a combinação de um benefício público específico. Uma Benefit Corporation deve também incluir um dos seguintes serviços públicos específicos: (i) fornecer produtos benéficos ou serviços a indivíduos ou comunidades; (ii) promover oportunidades econômicas para os indivíduos ou comunidades, que deve ir além da criação de postos de trabalho no curso normal da criação de um negócio; (iii) preservar o meio ambiente; (iv) melhorar a saúde humana; (v) promover as artes, as ciências ou avanço do conhecimento; (vi) aumentar o fluxo de capital a entidades com fins de utilidade pública ou (vii) a realização de qualquer outro benefício especial para a sociedade ou para o meio-ambiente (LAW FOR CHANGE, 2011).

\subsubsection{Perspectiva dos países emergentes}

Os negócios inclusivos entre os países emergentes, tanto na visão latino americana, quanto na visão asiática de Yunus apresentam aspectos semelhantes. Ambas as visões apontam os negócios inclusivos com forte preocupação na redução da pobreza e que sejam iniciativas que necessariamente tenham impacto social positivo, efetivo e, sobretudo, de longo prazo.

Buscou-se como principal referência para a compreensão da visão sobre os negócios inclusivos na América Latina, textos de pesquisadores da Social Enterprise Knowledge Network (SEKN), rede formada por grandes escolas de administração de empresas da América Latina e que busca avançar as fronteiras do conhecimento e prática de empresas sociais por meio da pesquisa colaborativa, aprendizado compartilhado, ensino por meio de casos, e do ensino de gestão de instituições sociais fortalecendo assim a capacidade de servir suas comunidades.

No caso da vertente asiática, o grande inspirador dos negócios sociais é Muhammad Yunus, prêmio Nobel da Paz, que constituiu o Grameen Bank e propagou pelo mundo suas idéias de microcrédito. Yunus é amplamente estudado em diversas partes do mundo e seu modelo é amplamente reconhecido e adotado, sobretudo em países como Bangladesh e Índia, mas também no Brasil, como por exemplo, o Banco Palmas. 
Para Yunus (2007, p. 28), existem dois tipos de negócios sociais: (i) o primeiro, são empresas que ao invés de focar suas atividades para a maximização do lucro dos proprietários, promovem beneficio social, por meio de investidores que buscam redução da pobreza, tratamento de saúde para pobres, justiça social, sustentabilidade global e assim por diante, buscando satisfação psicológica, emocional e espiritual ao invés de recompensas financeiras; (ii) o segundo opera de maneira diferente: negócio de maximização de lucro que é propriedade dos pobres ou marginalizados. Nesse caso, o benefício social deriva do fato de que os dividendos e o crescimento financeiro produzido serão para beneficiar os pobres reduzindo sua pobreza.

As empresas sociais para a rede SEKN (acesso em 21 de jan. de 2011) são definidas como organizações ou empreendimentos que geram transformação social por meio de atividades de mercado. Isso engloba ONGs, organizações privadas por lucro ou negócios engajados em atividades do setor público produzindo produtos e serviços de valores significativos. Segundo Marques et al (2009), um negócio inclusivo não basta ser apenas auto-sustentável, ele tem que ser rentável e é essencial a necessidade de transformação das condições de vida dos destinatários. A rentabilidade do negócio possibilita a garantia da continuidade da missão social proposta. Assim, "o acesso a bens de consumo com impacto direto nas condições sanitárias, e na construção de capacidades nos setores marginalizados, claramente conseguem transformar as condições de vida de seus destinatários” (MARQUES et al, 2009, p.29). Segundo a rede SEKN, portanto, o que determina se um negócio está ou não na categoria é o propósito social e não uma forma legal específica.

Pelo entendimento de Marques et al (2009), esses seriam negócios inclusivos apenas se, com distribuição dos produtos, atingirem a população marginalizada, que anteriormente não participava do mercado consumidor e que, com esses bens, possam melhorar a qualidade de vida e transformar realidades.

A visão latino-americana reforça também o papel das pequenas e médias organizações, de forma que a população de baixa renda muitas vezes participe também como produtores e não simplesmente como consumidores. 
Muitos autores defendem a idéia da não necessidade de regulação do Estado para esta nova forma organizacional. Segundo Austin (2000 apud REFICCO et al, 2006, p.407), “o determinante é a intenção explícita e consciente para criar valor para a comunidade, que vai além do benefício social gerado por uma empresa ao criar empregos."

Segundo Yunus (2007, p.33), essa coexistência de interesses é possível, porém, na vida real, seria muito difícil operar um mesmo negócio com dois objetivos conflituosos de maximização de lucro e de benefícios sociais.

Porém, sob o prisma da Nova Sociologia Econômica e sua visão do enraizamento social da economia, a coexistência desses interesses seria perfeitamente possível; visto que ambos os princípios funcionariam como nexos sociais de integração e geração de ordem, sendo portanto, estabilizadores das relações econômicas.

Yunus (2007, p.23-24) afirma que um negócio social se difere da caridade ou de uma ONG, pois como as tradicionais empresas maximizadoras de lucro, ele possui proprietários, que são autorizados a recuperar seus investimentos e que podem ser um único indivíduo, uma parceria, um ou mais investidores que contratam gestores para operar o negócio ou ainda, o governo ou filantropos ou qualquer combinação com diferentes tipos de negócios.

Segundo Marques et al (2006, p.29)

\begin{abstract}
a definição de um negócio inclusivo pretende traduzir a importância vital que tem alcançar a inclusão social das pessoas marginalizadas - enquanto consumidoras, prestadoras, distribuidoras - como resultado do empreendimento empresarial, diferenciando-as, assim das discussões centradas em geração de negócios na base da pirâmide ou de negócios com os pobres, onde estas são basicamente consumidoras.
\end{abstract}

\title{
2.4.2 Classificação dos trabalhos
}

Conforme citado anteriormente, uma das fontes de dados para o desenvolvimento do presente capítulo se deu através de um amplo levantamento em bases de dados de textos acadêmicos que se apropriam dos principais termos usados na temática desse trabalho.

O levantamento levou em conta três principais termos que foram pesquisados em 
português para as bases de dados nacionais e em inglês para as bases internacionais: empresas sociais, social enterprise, negócios inclusivos, inclusive business e negócios sociais, social business. Os termos foram pesquisados em seis bases de dados, sendo as nacionais CAPES, EnAnpad e SEMEAD e as internacionais EBSCO, PROQUEST e ISI. A metodologia e protocolos seguidos para a realização do levantamento, estão descritos no Anexo 1.

Com o objetivo de aprofundar o entendimento do tema na atualidade, isto é como o tema está sendo abordado nas pesquisas acadêmicas e ainda, quais os caminhos que as discussões têm seguido, decidiu-se não apenas discutir o conteúdo dos trabalhos, como feito anteriormente, mas também tipificar as abordagens feitas pelos autores pesquisados. Para tanto, buscou-se classificar os trabalhos encontrados a partir do levantamento bibliográfico, levando em conta três dimensões de análise realizadas para os temas: (i) artigos com foco na análise conceitual, (ii) artigos que apresentavam primordialmente uma análise sobre a questão da gestão das iniciativas e (iii) artigos que tinham por objetivo analisar os resultados e o impacto das iniciativas.

Dentre as três classificações, foi possível observar que poucos artigos analisavam os resultados e impacto das iniciativas, devido ser um fenômeno recente.

A seguir apresenta-se uma síntese de cada uma dessas dimensões. O debate não é exaustivo e objetiva-se apresentar, em linhas gerais, as direções que os trabalhos têm seguido ao discutir o tema dos negócios sociais.

\subsubsection{Análise conceitual}

Considerou-se nesta dimensão os textos com enfoque principal na análise dos conceitos de pelo menos um dos três temas pesquisados: empresas sociais (social enterprise), negócios inclusivos, (inclusive business) e negócios sociais, (social business).

Dentre os cento e oito textos encontrados no levantamento bibliográfico, quarenta e um apresentaram análise conceitual dos temas pesquisados. Sete artigos utilizavam abordagem norte-americana, trinta e um apresentavam abordagem européia e três com 
abordagem dos países emergentes.

Muitos deles buscam definir esses conceitos baseado na realidade regional (LARATTA, 2009; LINDSAY; HEMS, 2004; MANCINO, 2005, SHAH, 2009; SMITH, 2008; GRANT, 2008; MINARD; SARA, 2009).

Alguns dirigem a discussão para a questão terminológica (JONES, KEOGH, 2006; TREXLER, 2008) ou ainda mais institucional, explorando aspectos da legitimidade (REAVY, 1994), propondo-se a contribuir melhor para o entendimento conceitual, trabalhando em uma linha contínua tipológica de organizações, que parte desde o modelo das organizações sem fins lucrativos e não governamentais até o empreendedorismo corporativo (DIOCHON, ALISTAIR, 2009; SHAW, CARTER, 2009).

Apenas um dos trabalhos analisados teve como objetivo comparar o conceito norteamericano com o europeu, apontando suas principais diferenças (KERLIN, 2006).

Conceitos que já são amplamente discutidos na literatura, como por exemplo, empreendedorismo social, responsabilidade social empresarial, cidadania corporativa, accountability, filantropia empresarial, desenvolvimento sustentável, governança corporativa, ética e moral surgem em alguns artigos associados a um dos três temas pesquisados no levantamento bibliográfico (empresas sociais, negócios sociais e negócios inclusivos) (REFICCO et al, 2009; BULL, 2008; CHELL, 2007; CURTIS, 2008).

Outros trabalhos apontavam conceitos complementares, já em um aprofundamento dos temas pesquisados. A questão da regulação aparece em trabalhos, discute-se a importância de novas legislações, bem como de alternativas para as empresas sociais (GALERA, BORZAGA, 2009; O’SHAUGHNESSY, 2008)

Amim (2009) desenvolveu em seu artigo, o conceito de Social Economy que seriam trabalhados por cooperativas, caridades, redes informais de troca, community ventures. A definição exata para o termo seriam atividades econômicas que privilegiam 
necessidades sociais, envolvendo comunidades ou pessoas desprivilegiadas na cadeia produtiva (produção e consumo).

Brown (2006) desenvolve o conceito de equity finance para empresas sociais e aponta para uma série de opções de design de equity finance considerando as motivações sociais dos investidores.

Cooney (2006) traz uma visão geral das tendências comerciais de empresas sociais. Di Domenico (2009) aborda a questão das alianças e colaboração inter-organizacional. Conceitos como Fair Trade (HUYBRECHTS, DEFOURNY, 2008) e Facility Management (KASIM, HUDSON, 2006) também aparecem como temas concomitantes.

Alguns trabalhos discutem um dos três conceitos pesquisados, levando em conta o papel do empreendedor social (THOMPSON, 2008; PARKINSON, HOWORTH, 2008), até mesmo em alguns casos comparando com o empreendedor tradicional (PRABHU, 1999; SPEAR, 2006).

Finalmente, alguns trabalhos discutem a questão do ensino do social enterprise nas escolas de administração (HAUGH, RUBERY, 2005; GUTHRIE, DURAND, 2008), bem como as metodologias de pesquisa do tema (PEATTIE, MORLEY, 2008).

\subsubsection{Análise da gestão}

Considerou-se nesta dimensão os textos com enfoque principal na análise da gestão e do funcionamento das organizações. Dentre os cento e oito textos encontrados no levantamento bibliográfico sobre empresas sociais, social enterprise, negócios inclusivos, inclusive business e negócios sociais, social business, cinqüenta apresentaram o aspecto da gestão como um dos focos da pesquisa. Oito artigos utilizavam abordagem norte-americana, trinta e três apresentavam abordagem européia e nove com visão dos países emergentes.

A maior parte dos artigos classificados com foco na análise da gestão dos negócios inclusivos eram estudos de casos. Os temas se dividiam entre as diversas áreas da 
administração como financeira, gestão de pessoas, marketing, estratégia ou ainda discutiam temas que também estão sendo debatidos nas diversas organizações como a responsabilidade social (CORNELIUS et al, 2008; MANFREDI, 2005), a governança (CURRY et al, 2009; LOW, 2006; RIDLEY-DUFF, 2009; RUYS, 2007; SPEAR et al, 2009), modelos de negócios colaborativos, alianças e parcerias (GRADL, KRÄMER, 2010; MUNOZ, 2010; MUNOZ, 2009),

Dentro da área financeira surgiram temas como a geração de receita, os financiamentos bancários, o investimento social privado e a lucratividade dos negócios (GHALIB et al, 2009; EDERY, 2006; NWANKWO et al, 2006)

Alguns dos textos com enfoque em gestão de recursos humanos (CORNELIUS et al, 2008) também abordaram questões como o voluntariado (MAWSON, 2010; MCBREARTY, 2007) e capacity building (TRODES et al, 2006).

$\mathrm{Na}$ área da estratégia, as questões giravam em torno do nascimento das organizações inclusivas, das barreiras de entrada, do crescimento e do potencial de escala (GHALIB et al, 2009; ISLAM, 2007; HYNES, 2009; HORST, 2008; VANSANDT et al, 2010). Trabalhos também discutiam os pontos críticos de sucesso para esse tipo de negócio e os desafios e oportunidades (CHAWLA, 2007; DEFOURNY, NYSSENS, 2008, LYNCH et al, 2008; LYON, RAMSDEN, 2006).

Dentro do grupo dos textos de estratégia, apareceram também aqueles que abordavam ferramentas de gestão como o Balanced Score Card (BSC) (BULL, CROMPTON, 2006), o Social Accounting (GIBBON, AFFLECK, 2008) e o Resource Management (ROYCE, 2007).

$\mathrm{Na}$ área de marketing, os autores se concentraram na discussão da inovação de produtos (PITTA, KUCHER, 2009; SHAW, 2004), visto que muitos negócios inclusivos têm por objetivo solucionar um problema social por meio da tecnologia e criação de novos produtos.

Alguns autores abordaram, ainda, temas secundários que envolviam formas ou 
estruturas diferenciadas de gestão como as microfinanças (CULL, 2009; GHALIB et al, 2009) e o cooperativismo ou empresas comunitárias (BERKES, DAVIDSON-HUNT, 2007; CURRY et al, 2009; RIDLEY-DUFF, 2009).

A figura do empreendedor também aparece como peça chave de alguns estudos de gestão dos negócios sociais (AL-ALAK, 2010; DIXON, CLIFFORD, 2007; HYNES, 2009).

\subsubsection{Análise dos resultados}

Considerou-se nesta dimensão os textos com enfoque principal na análise dos resultados e impacto dos negócios inclusivos. Dentre os cento e oito textos encontrados no levantamento bibliográfico sobre empresas sociais, social enterprise, negócios inclusivos, inclusive business e negócios sociais, social business, dezessete apresentaram a análise de resultados como um dos focos da pesquisa ao estudar esse tipo de iniciativa. Nenhum deles partia da abordagem norte-americana, quatorze apresentavam abordagem européia e três com visão dos países emergentes.

A maior parte dos artigos sobre análise de resultado e impacto, assim como os que analisaram a gestão, também eram estudos de casos.

Alguns textos analisavam o uso de ferramentas para avaliação de desempenho (performance) em negócios sociais (BULL, 2007; VIDAL, 2005), como o Organizational Life Cicle (BULL et al, 2008).

Outros propunham um modelo para a análise do retorno social dos investimentos (social return investments) de ações dessas organizações (ROTHEROE, RICHARDS, 2007; MCLOUGHLIN, 2009).

Autores como Ndemo e Bitange (2006), Ho e Chan (2010), Borza et al (2009) buscaram analisar o impacto das iniciativas de um negócio inclusivo sob o ponto de vista do desenvolvimento de um país. Harding (2004) apresenta em seu trabalho, o potencial econômico de uma iniciativa de negócio social. 
Darby e Jenkins (2006) analisam o impacto da gestão de um negócio inclusivo com base em indicadores de sustentabilidade entre outras formas de avaliar esse tipo de organização.

Finalmente, Thomas (2004), Sharpen (2006) e Chapman et al (2007) mostram os fatores de crescimento desse tipo de organização e analisam os resultados de suas ações, não considerando apenas o aspecto gerencial.

\subsubsection{Modelo teórico utilizado}

A partir da presente discussão, é possível sintetizar os principais aspectos entre as diferentes visões, representados a seguir.

\section{Quadro 1 - Diferentes visões dos negócios sociais}

\begin{tabular}{|c|c|c|c|}
\hline & Européia & Norte-Americana & Países Emergentes \\
\hline Origem & $\begin{array}{l}\text { Economia social e } \\
\text { cooperativismo }\end{array}$ & Expansão do terceiro setor & $\begin{array}{l}\text { Alternativas no combate à } \\
\text { pobreza }\end{array}$ \\
\hline Papel & Colaborar com o setor público & $\begin{array}{l}\text { Participar do mercado com } \\
\text { inovações sociais }\end{array}$ & $\begin{array}{l}\text { Redução da pobreza e inclusão } \\
\text { (usa termo negócios inclusivos) }\end{array}$ \\
\hline $\begin{array}{l}\text { Recursos } \\
\text { financiados }\end{array}$ & Maior parte são públicos & Maior parte são privados & $\begin{array}{l}\text { Híbrido, mas gerador de } \\
\text { receitas }\end{array}$ \\
\hline $\begin{array}{l}\text { Principal } \\
\text { característica }\end{array}$ & $\begin{array}{l}\text { Prestação de serviço público e } \\
\text { modelo de governança: coletivo, } \\
\text { transparência, participativo }\end{array}$ & $\begin{array}{l}\text { Não há modelo de governança } \\
\text { restrito, focado na ação de um } \\
\text { empreendedor ou empresa }\end{array}$ & $\begin{array}{l}\text { Impacto social efetivo e de } \\
\text { longo prazo }\end{array}$ \\
\hline População & $\begin{array}{l}\text { População marginalizada, grupos } \\
\text { desfavorecidos são atendidos }\end{array}$ & Consumidores e/ou atendidos & Produtores e/ou consumidores \\
\hline Lucros & $\begin{array}{l}\text { Reinvestidos na organização ou } \\
\text { retorno para stakeholders } \\
\text { (comunidade) com propósito de } \\
\text { inclusão social. É um meio. }\end{array}$ & $\begin{array}{l}\text { Indiferente, mas que gere } \\
\text { impacto social }\end{array}$ & $\begin{array}{l}\text { Reinvestidos na organização ou } \\
\text { um fim em si mesmo quando } \\
\text { proprietários são população } \\
\text { excluída }\end{array}$ \\
\hline Formas legais & Indiferente & $\begin{array}{l}\text { Tendência de uma nova } \\
\text { estrutura legal: L3C - B-corp }\end{array}$ & $\begin{array}{l}\text { Indiferente, mas com geração } \\
\text { de receita }\end{array}$ \\
\hline Foco principal & $\begin{array}{l}\text { Solucionar problemas sociais } \\
\text { como o desemprego }\end{array}$ & $\begin{array}{l}\text { Impacto social por meio de uma } \\
\text { atividade comercial }\end{array}$ & $\begin{array}{l}\text { Inclusão da população } \\
\text { marginalizada }\end{array}$ \\
\hline
\end{tabular}

Propõe-se aqui adotar uma definição operacional e um modeo teórico a ser utilizada neste trabalho sobre o entendimento do que seria um negócio inclusivo. Estes aspectos poderão servir como base para outros estudos em negócios sociais e negócios inclusivos.

Para todas as perspectivas estudadas, os negócios inclusivos devem: (i) ter propósito 
social, com o papel de solucionar problemas que vão além da geração de emprego e da acessibilidade de produtos por um sistema de preço; (ii) ser orientado para produção e venda de produtos e/ou serviços no mercado, apresentando soluções para problemas sociais; (iii) possuir diversas formas legais - desde associações até empresas (corporações, sociedades limitadas, anônimas, etc.), mas necessariamente organizações privadas e autônomas, isto é, não fazem parte do setor público, possuem empregados contratados e assumem risco econômico, exercendo atividade de mercado; (iv) lucro investido prioritariamente para atingir metas sociais.

O conceito norte-americano reforça a ação empreendedora de um indivíduo que alcança objetivos sociais por meio de um negócio, participando como qualquer outra empresa no mercado. Já o conceito europeu reforça o coletivo, as decisões participativas e coloca em debate temas como prestação de contas e governança.

$\mathrm{Na}$ visão americana, as empresas que praticam ações de responsabilidade social corporativa, em certa medida, são consideradas empresas sociais. Isso não ocorre na perspectiva européia, na qual a responsabilidade social corporativa faz parte das funções da empresa, promovendo práticas para melhorar as condições de vida de seus empregados ou diminuir o impacto ambiental negativo causado por sua produção.

As empresas sociais dentro do conceito europeu, diferentemente da norte-americana, possuem como característica essencial a prestação de serviços públicos, e em sua maioria, são financiadas com recursos governamentais. Ainda na visão européia, o lucro é apenas um meio de alcançar o alvo de interesse coletivo e nunca um fim em si mesmo.

A função pública de uma empresa social na perspectiva européia se assemelha muito à Organização Social (OS) regulamentada no Brasil. Segundo o Ministério do Planejamento (acesso em 20 de janeiro de 2011), uma Organização Social é uma qualificação dada às entidades privadas sem fins lucrativos (associações, fundações ou sociedades civis), que exercem atividades de interesse público. Esse título permite que a organização receba recursos orçamentários e administre serviços, instalações e equipamentos do Poder Público, após ser firmado um Contrato de Gestão com o Governo Federal. No Brasil essas organizações não são vistas como um negócio 
inclusivo, mesmo tendo as mesmas características de uma empresa social na visão européia.

Outra questão que surge e que não tem seu limite muito bem definido, é a distribuição de lucros. Parece haver um conflito de agência ao se falar que as empresas, que têm por princípio a maximização do resultado financeiro a interesse dos acionistas e proprietários, podem também maximizar objetivos sociais atendendo aos interesses das comunidades e de outros stakeholders. Por outro lado, ao se criar modelos híbridos de organizações sem fins lucrativos e organizações por lucro, é possível entrar em um acordo formal onde se garanta o investimento prioritário em ações sociais, porém na prática esses modelos são difíceis de serem operados.

É de se observar que independente do contexto, é essencial atrair investidores para os negócios inclusivos, aumentando o impacto do negócio. Além disso, muitas das inovações criadas para solucionar problemas sociais estão relacionadas ao desenvolvimento de algum tipo de tecnologia e, por isso, exigem da organização, mais recursos para se consolidarem no mercado. A legislação L3C criada nos Estados Unidos é apenas uma forma de atrair capital, e ao mesmo tempo limita o conflito de agência entre geração de lucro e impacto social, garantindo o cumprimento da missão social e atraindo interesses de investidores.

No âmbito de discussão acadêmica, é preciso uma definição clara que delimite em que medida o lucro é possível e qual o peso da questão social na atuação da organização.

O presente trabalho adota o uso do termo negócios inclusivos e o enfoque dado para o este conceito no estudo se baseia, principalmente, na perspectiva dos países emergentes.

A adoção do termo negócios inclusivos neste trabalho se deu, porque a iniciativa estudada é um negócio que está voltado à geração de oportunidades de emprego e renda para grupos com baixa ou nenhuma mobilidade no mercado de trabalho, dentro dos padrões do chamado "trabalho decente" e de forma auto-sustentável, ou seja, gerando lucratividade para os empreendimentos, e que estabelecem relações com organizações empresariais típicas, quer seja na condição de fornecedores de produtos ou serviços, 
quer seja na distribuição dessa mesma produção das empresas ou negócios tradicionais.

Assim, será utilizada a definição a seguir para negócios inclusivos: toda organização que tem por objetivo melhorar a qualidade de vida de pessoas em vulnerabilidade social, por meio de uma atividade de mercado, utilizando práticas empresariais, gerando rentabilidade econômica e reinvestindo seus dividendos em sua missão social.

Uma característica possível nesse tipo de organização é a possibilidade de receber recursos de investidores (social venture capital) para iniciar suas atividades ao invés de doações. Neste caso, o retorno do investimento poderá ser distribuído aos investidores, mas em longo prazo e de forma conservadora, de modo que os resultados financeiros devam ser prioritariamente reinvestidos na própria organização.

O modelo teórico utilizado neste trabalho é apresentado a seguir em dois quadros. O primeiro, apresenta de forma introdutória, o contexto e o segundo, o modelo de negócio.

\section{Quadro 2 - Contexto}

\begin{tabular}{|l|l|}
\hline & \multicolumn{1}{c}{ Contextualização } \\
\hline Contexto & Problema \\
\hline - Mercado & - Cenário em cada país \\
\hline - Descrição da população \\
\hline - Surgimento da iniciativa \\
\hline - Desenvolvimento da cadeia produtiva \\
\hline
\end{tabular}


Quadro 3 - Modelo de negócio

\section{Modelo teórico: FCS - Ecossistema - Negócios inclusivos}

\begin{tabular}{|c|c|}
\hline \multicolumn{2}{|c|}{ Modelo de negócio } \\
\hline Atividade organizacional & Atividades essenciais \\
\hline Pilares (FCS) & $\begin{array}{l}\text { Fatores Críticos de Sucesso: } \\
\text { - Novas unidades } \\
\text { - Contrapartida da organização }\end{array}$ \\
\hline Análise estratégica (Ecossistema) & $\begin{array}{l}\text { - Cadeia de valor: } \\
\text { - Inovação tecnológica } \\
\text { - } \text { Delhoria de produtos } \\
\text { produtos - Marketing } \\
\text { - Posicionamento do produto } \\
\text { no mercado (preço, } \\
\text { qualidade) } \\
\text { - Barreiras enfrentadas pela } \\
\text { população envolvida } \\
\text { - Parcerias (internas e externas) } \\
\text { - } \text { suptrutura da cadeia de } \\
\text { - Gestão de pessoas } \\
\text { - Cultura organizacional } \\
\text { - Trasadua social: } \\
\text { - Participação da população } \\
\text { envolvida } \\
\text { - Diferencial que o torna } \\
\text { negócio inclusivo }\end{array}$ \\
\hline Funcionamento de cada unidade & $\begin{array}{l}\text { - Estrutura organizacional } \\
\text { - Cargos } \\
\text { - Competências } \\
\text { - Porte } \\
\text { - Valor finaceiro } \\
\text { - Valor social }\end{array}$ \\
\hline
\end{tabular}




\section{PROCEDIMENTOS METODOLÓGICOS}

Este trabalho caracteriza-se como um estudo de caso. A construção do método de investigação será descrita no presente capítulo. O referencial teórico possibilitou a operacionalização do estudo, tanto na construção do instrumento de coleta, quanto na escolha mais adequada da classificação da pesquisa.

Para a construção deste trabalho, bem como para alcançar os objetivos pretendidos, utilizou-se a pesquisa bibliográfica, especialmente na fundamentação teórica. Para tanto, foi feita uma ampla pesquisa em bases nacionais e internacionais com o intuito de compreender o que se tem escrito sobre esse tema.

Para aprofundar e sistematizar os conceitos existentes e compreender os fenômenos atuais, foi realizada uma pesquisa exploratória utilizando-se do estudo de caso de um modelo de negócio aplicado a três diferentes países.

A escolha da iniciativa foi feita segundo os critérios: (i) definir-se como um negócio inclusivo (ii) ser reconhecida por sua atuação social; (iii) comercializar um produto que seja essencial para a sustentação e rentabilidade do modelo de negócio; (iv) ser uma organização com a qual a autora já mantinha contato profissional.

$\mathrm{Na}$ seqüência é apresentada uma matriz que resume o problema da pesquisa, seus objetivos, bem como os pontos de investigação a ser desenvolvido para cada uma das etapas da pesquisa. 
Quadro 4 - Matriz de amarração

\begin{tabular}{|c|c|c|c|c|c|c|c|}
\hline \multicolumn{2}{|c|}{ Objetivos da pesquisa } & \multirow{2}{*}{$\begin{array}{l}\text { Pontos de investigação } \\
\text { (Questões da Pesquisa) } \\
\text { Informações necessárias }\end{array}$} & \multirow{2}{*}{$\begin{array}{c}\text { Fundamen- } \\
\text { tação } \\
\text { teórica }\end{array}$} & \multirow{2}{*}{$\begin{array}{c}\text { Técnicas de } \\
\text { coleta dos } \\
\text { dados }\end{array}$} & \multirow{2}{*}{$\begin{array}{l}\text { Técnicas } \\
\text { de análise } \\
\text { dos dados }\end{array}$} & \multirow{2}{*}{$\begin{array}{l}\text { Resulta- } \\
\text { do } \\
\text { esperado }\end{array}$} & \multirow{2}{*}{$\begin{array}{l}\text { Apresenta- } \\
\text { ção do } \\
\text { resultado }\end{array}$} \\
\hline geral & Específicos & & & & & & \\
\hline \multirow{3}{*}{$\begin{array}{l}\text { Analisar as } \\
\text { características de } \\
\text { um negócio } \\
\text { inclusivo e os } \\
\text { fatores que } \\
\text { facilitam ou } \\
\text { dificultam sua } \\
\text { implementação }\end{array}$} & $\begin{array}{c}\text { Discutir as } \\
\text { diferentes } \\
\text { perspectivas } \\
\text { sobre os } \\
\text { negócios } \\
\text { sociais e } \\
\text { negócios } \\
\text { inclusivos, } \\
\text { ampliando o } \\
\text { escopo de } \\
\text { análise }\end{array}$ & $\begin{array}{l}\text { Quais as características de negócios inclusivos, empresa social e negócios } \\
\text { inclusivos? Qual a visão norte- americana? Qual a visão européia? Qual a } \\
\text { visão dos países emergentes? Quais as principais semelhanças e diferenças } \\
\text { entre elas? Quais são os pontos comuns em todos os entendimentos sobre } \\
\text { negócios inclusivos? O que diferencia negócios inclusivos de outras } \\
\text { organizações? Qual a definição que será usada no trabalho? }\end{array}$ & $\begin{array}{c}\text { Negócio Social } \\
\text { Empresa Social } \\
\text { Negócios } \\
\text { Inclusivos }\end{array}$ & $\begin{array}{c}\text { Revisão } \\
\text { teórica }\end{array}$ & $\begin{array}{l}\text { Leitura / } \\
\text { Análise }\end{array}$ & $\begin{array}{c}\text { Definição } \\
\text { usada no } \\
\text { trabalho }\end{array}$ & $\begin{array}{l}\text { Cap. } 2 \text { - } \\
\text { Revisão } \\
\text { teórica }\end{array}$ \\
\hline & $\begin{array}{c}\text { Analisar as } \\
\text { características } \\
\text { do modelo de } \\
\text { negócio de um } \\
\text { negócio } \\
\text { inclusivo, } \\
\text { segundo o } \\
\text { conceito de } \\
\text { ecossistemas }\end{array}$ & $\begin{array}{l}\text { Como é a cadeia de valor/ cadeia produtiva onde o negócio inclusivo está } \\
\text { inserido? Qual a criação de valor econômico e qual a criação de valor } \\
\text { social? Como é o sistema de valor ou cadeia estendida? Quem são os atores } \\
\text { fora da cadeia? Como cada um desses atores interage? Outros aspectos } \\
\text { ecossistema (história, realidade social, econômica, política, cultural)? Quem } \\
\text { são as organizações suporte? Qual o modelo de governança utilizado? }\end{array}$ & $\begin{array}{c}\text { Teoria de } \\
\text { Ecossistema }\end{array}$ & $\begin{array}{l}\text { Revisão } \\
\text { teórica / } \\
\text { Estudo de } \\
\text { Caso }\end{array}$ & $\begin{array}{l}\text { Leitura / } \\
\text { Análise } \\
\text { Entrevis- } \\
\quad \text { tas }\end{array}$ & $\begin{array}{c}\text { Definição } \\
\text { usada no } \\
\text { trabalho } \\
\text { Caso }\end{array}$ & $\begin{array}{l}\text { Cap. } 2 \text { - } \\
\text { Revisão } \\
\text { teórica } \\
\text { Cap. } 4 \text { - } \\
\text { Estudo de } \\
\quad \text { Caso }\end{array}$ \\
\hline & $\begin{array}{l}\text { Comparar nos } \\
\text { estudos de caso } \\
\text { de cada país os } \\
\text { fatores que } \\
\text { contribuem, de } \\
\text { forma positiva } \\
\text { e negativa, na } \\
\text { implementação } \\
\text { do negócio } \\
\text { inclusivo. }\end{array}$ & $\begin{array}{l}\text { Quais os principais desafios enfrentados em cada país em cada uma das } \\
\text { fases (implementação, desenvolvimento)? Quais as facilidades/ dificuldades } \\
\text { encontradas em cada região? Quais os principais elementos necessários } \\
\text { para um negócio inclusivo bem sucedido? O que estimulou cada um dos } \\
\text { negócios inclusivos a iniciar atividades? Quais os principais desafios a } \\
\text { serem superados? Quais os fatores críticos de sucesso em cada um dos } \\
\text { países? Quais características asseguram uma implementação efetiva? }\end{array}$ & $\begin{array}{l}\text { Fatores críticos } \\
\text { de sucesso }\end{array}$ & $\begin{array}{l}\text { Revisão } \\
\text { teórica / } \\
\text { Estudo de } \\
\text { Caso }\end{array}$ & $\begin{array}{l}\text { Leitura / } \\
\text { Análise } \\
\text { Entrevis- } \\
\quad \text { tas }\end{array}$ & $\begin{array}{c}\text { Definição } \\
\text { usada no } \\
\text { trabalho } \\
\text { Caso }\end{array}$ & $\begin{array}{c}\text { Cap. } 2 \text { - } \\
\text { Revisão } \\
\text { teórica } \\
\text { Cap. } 4 \text { - } \\
\text { Estudo de } \\
\text { Caso }\end{array}$ \\
\hline
\end{tabular}




\title{
3.1 Tipo de Pesquisa
}

Esta é uma pesquisa de abordagem qualitativa e objetivo exploratório. Um estudo qualitativo se justifica, pois é capaz de revelar uma riqueza maior de dados. Pelo fato dos negócios inclusivos serem um tema muito recente, o uso dessa abordagem permite um melhor aprofundamento do estudo, possibilitando uma exploração maior de eventuais contradições e paradoxos existentes.

Conforme Malhotra (1996, p.156),

\begin{abstract}
a pesquisa com dados qualitativos é a principal metodologia utilizada nos estudos exploratórios e consiste em um método de coleta de dados não-estruturado, baseado em pequenas amostras e cuja finalidade é promover uma compreensão inicial do conjunto do problema de pesquisa.
\end{abstract}

Godoy (1995, p.58) explicita algumas características desse tipo de pesquisa que deve: considerar o ambiente como fonte direta dos dados e o pesquisador como instrumento chave; possuir caráter descritivo; o processo ser o foco principal de abordagem e não o resultado ou o produto; a análise dos dados ser realizada de forma intuitiva e indutivamente pelo pesquisador; não requer o uso de técnicas e métodos estatísticos; e, por fim, ter como preocupação maior a interpretação de fenômenos e a atribuição de resultados.

Neste estudo, portanto, o ambiente terá papel fundamental. Serão analisados não só aspectos do ecossistema, mas por meio do pesquisador serão extraídas das pessoas atuantes na organização, informações essenciais para a descrição da experiência de um negócio inclusivo em três diferentes continentes. Por terem poucos trabalhos desenvolvidos com o foco em negócios inclusivos, a descrição e a interpretação dos fenômenos passam a ser de extrema importância para a concepção deste novo conceito.

Gil (1999, p.43) afirma que,

um trabalho é de natureza exploratória quando envolver levantamento bibliográfico, entrevista com pessoas que tiveram (ou têm) experiências práticas com o problema pesquisado e análise de exemplos que estimulem a compreensão. Possui ainda a finalidade básica de desenvolver, esclarecer e modificar conceitos e idéias para a formulação de abordagens posteriores.

As pesquisas exploratórias, segundo Gil (1999, p.43) visam proporcionar uma visão geral 
de um determinado fato, do tipo aproximativo.

Utilizando essa abordagem, o presente trabalho visa compreender os fenômenos segundo as perspectivas dos sujeitos, por meio de um estudo comparativo internacional, com a pretensão de colaborar com uma melhor compreensão do conceito de negócios inclusivos.

\subsection{Método de pesquisa}

O método de pesquisa utilizado é o de estudo de caso. Segundo definição de Yin (2005, p.32), "um estudo de caso é uma investigação empírica que investiga um fenômeno contemporâneo dentro de seu contexto da vida real, especialmente quando os limites entre o fenômeno e o contexto não estão claramente definidos."

Segundo Gil (2009, p.14), os estudos de caso "são úteis para proporcionar uma visão mais clara acerca de fenômenos pouco conhecidos." O autor afirma que se comparado com outros métodos ele apresenta uma série de vantagens como, por exemplo, possibilitar estudo de um caso em profundidade.

Assim, a descrição deste fenômeno recente, bem como o uso de entrevistas em profundidade, poderão contribuir para a evolução do tema no ambiente acadêmico.

\subsection{Coleta de dados}

Foram dois os tipos de coleta de dados. Primeiramente foi realizado um levantamento de dados secundários com documento e informações sobre a organização estudada, com o intuito de desenvolver um olhar específico e objetivo com relação à organização. Foram coletados materiais dos três países, onde a organização está presente. Esse levantamento deu subsídio para a análise do estudo de caso e melhor entendimento da organização.

Em seguida, foram realizadas entrevistas, instrumento essencial de coleta de dados para o trabalho de campo e para a compreensão dos fenômenos estudados na organização. Essa etapa visou comparar as características de um negócio inclusivo existente em três diferentes países, analisando os fatores facilitadores e difucultadores em sua implementação, ressaltando os desafios presentes em cada país. 
Cada uma das etapas de coleta foi descrita em profundidade no item a seguir, bem como procedimentos de confiabilidade dos dados coletados.

\subsubsection{Coleta de dados secundários}

O levantamento de dados secundários sobre o caso estudado foi realizado com o intuito de complementar e corroborar os dados coletados nas entrevistas e dar suporte à etapa de análise de dados. Ele foi realizado em uma etapa importante do trabalho, concomitante com a análise do estudo de caso.

Documentos como plano de negócios da organização, metas e projeção de vendas, balanço social, contrato social, prestação de contas para stakeholders entre outros documentos de gestão foram solicitados separadamente a cada uma das três unidades distribuídas nos diferentes continentes.

\subsubsection{Entrevistas}

O presente trabalho se utilizou de entrevistas como técnica de coleta de dados primários, mais precisamente a técnica de entrevista em profundidade.

Segundo MARTINS (2002), a metodologia de entrevista consiste em um processo de interação social entre duas pessoas na qual uma delas, o entrevistador, tem por objetivo a obtenção de informações por parte do outro, o entrevistado. No caso desta pesquisa, houve mais de um entrevistado e estes não tinham necessariamente a mesma posição na organização.

Para Gil (2009, p.62), “a entrevista é provavelmente a mais importante dentre as técnicas utilizadas no âmbito das ciências sociais".

Para compreender melhor o procedimento buscou-se entender como é dado o processo de entrevista, que é definido por Rosa e Arnoldi (2008, p.17), como:

[...] uma das técnicas de coleta de dados considerada como sendo uma forma racional de conduta do pesquisador, previamente estabelecida, para dirigir com eficácia um conteúdo sistemático de conhecimentos, de maneira mais completa possível, com o mínimo de esforço de tempo. 
Gorden (1975) afirma que essa técnica de coleta depende de elementos internos, contidos na micro-situação da entrevista, que seriam: entrevistador, entrevistado e tema; e elementos externos, contidos da macro-situação: sociedade, comunidade e cultura.

Romanelli (1998, p. 125-126) afirma que a

entrevista é uma relação diádica, que cria uma forma de sociabilidade específica, limitada no tempo, sem continuidade, em que, inicialmente, os parceiros da díade se defrontam como estranhos pautados por uma alteridade que aparentemente não admite o encontro e que deve ser superada para que a matéria-prima do conhecimento possa ser produzida durante esse encontro que transforma estranhos em parceiros de uma troca.

De certa forma, por não ser uma relação de diálogo e sim de questionamentos, e ainda, por existir uma relação de confiança necessária, como é possível depreender do trecho citado acima, o entrevistado exprime suas opiniões e sentimentos sem que haja juízo de valor por parte do entrevistador.

Autores (ROSA, 2008; ROMANELLI, 1998 e BIASOLI-ALVES, 1998 apud ROSA e ARNOLDI, 2008; CALDEIRA, 1980; apud ROMANELLI, 1998) consideram alguns aspectos como sendo necessários para produção de conteúdo e análise de discurso a partir de entrevistas, explorados aqui de uma forma não exaustiva: (i) empatia entre entrevistado e entrevistador, facilitando a relação de confiança entre ambos; (ii) caso ocorram assuntos não relacionados a temas da entrevista, prudente concessão, sem intervenção do entrevistador; (iii) considerar na análise, a subjetividade existente entre entrevistador e entrevistado; (iv) capacidade do entrevistador em selecionar e distinguir respostas ligadas ao tema, estabelecendo limites no momento da análise de dados; (v) ter em mente que o conteúdo trazido pelo entrevistado é expresso por falas que são elaboradas e reproduzidas por indivíduos com diversos recursos reflexivos e com diversos graus de expressão verbal e, portanto, ter perdas de qualidade.

Sendo assim, pode-se concluir que a entrevista é um processo complexo de coleta de dados no qual é necessário levar em conta procedimentos específicos para geração de um conteúdo verídico.

Existem diversos tipos de entrevista: as classificadas por nível de estruturação e roteiro (estruturadas, semi-estruturadas, abertas, guiadas, por pautas ou informais), as classificadas por seu objetivo (entrevista de diagnóstico, de investigação, terapêutica) ou 
ainda, aquelas mais específicas como a entrevista especializada ou de elites e a entrevista em profundidade, escolhida como instrumento de coleta para o presente trabalho.

Valles (2000, p.198) levanta na literatura outros termos usados para designar entrevista em profundidade como: entrevista bibliográfica, entrevista intensiva, entrevista individual aberta, entrevista individual semi-aberta, entrevista longa. Nesse trabalho optou-se por utilizar o termo entrevista em profundidade por ter seu uso mais freqüente na literatura pesquisada.

\subsubsection{Entrevista em profundidade}

Segundo Rosa e Arnoldi (2008), o referencial teórico é um filtro através do qual o pesquisador passa a enxergar, com exatidão, a realidade, sugerindo perguntas e indicando possibilidades viáveis.

Os fatores críticos de sucesso, para os negócios inclusivos, encontrados na literatura, bem como a teoria de ecossistemas foram dois pilares na construção de um roteiro ou entrevista semi-estruturada.

A entrevista semi-estruturada se inicia:

partindo de alguns questionamentos básicos, apoiados em teorias e hipóteses, que interessam à pesquisa e que, em seguida, oferecem amplo campo de interrogativas, fruto de novas hipóteses que vão surgindo à medida que se recebem as respostas do entrevistado. Este, seguindo espontaneamente a linha de seu pensamento e de suas experiências dentro do foco principal colocado pelo investigador, começa a participar na elaboração do conteúdo da pesquisa. É útil esclarecer que essas perguntas fundamentais que constituem, em parte, a entrevista semi-estruturada, são resultado não só da teoria que alimenta a ação do investigador mas, também, de toda a informação que ele já recolheu sobre o fenômeno que interessa. (NOGUEIRA-MARTINS e BÓGUS, 2004, p.49).

O protocolo para o estudo de caso tem em sua base a discussão metodológica e o roteiro da entrevista a ser realizada. Ele é o apoio para condução do entrevistador na realização das entrevistas em profundidade.

Com relação à condução de entrevista em profundidade, Malhotra (2001, p.163) destaca que "mesmo que o entrevistador procure seguir um esboço pré-determinado, o fraseado específico das perguntas e a ordem de sua formulação acabam sendo influenciados pelas respostas do entrevistado". 
Para o planejamento das entrevistas em profundidade foi adotado o roteiro abaixo que Mason (1996) apud COSTA et al apresenta:

Figura 3 - Roteiro de planejamento e preparação de entrevistas qualitativas

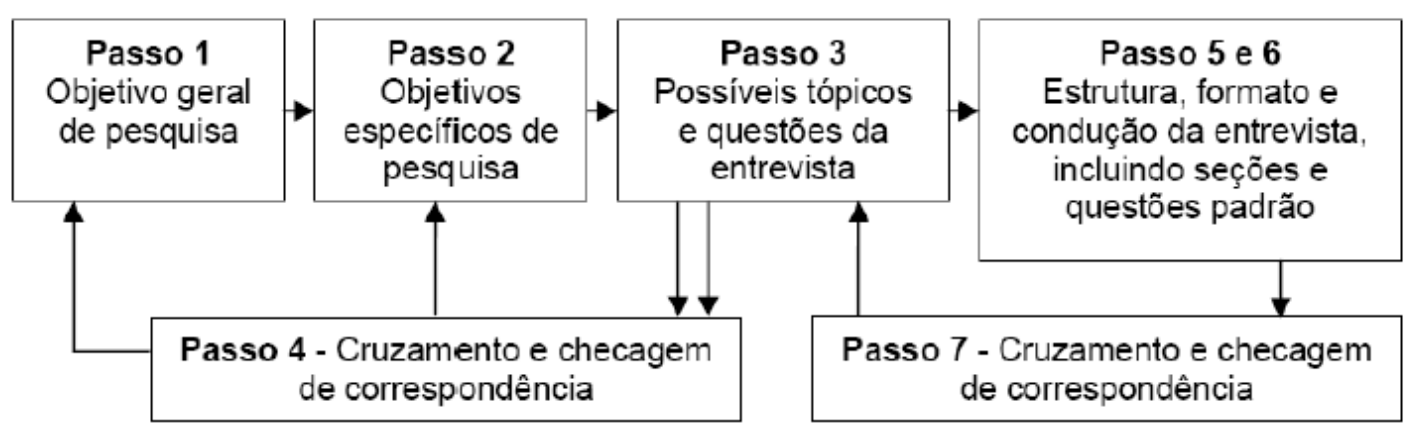

Fonte: MASON, 1996, p. 52 apud COSTA et al

A opção por entrevistas com roteiro semi-estruturado se deu em função dos seguintes aspectos apontados por Rosa e Arnoldi (2008, p.30):

(i) permite ao respondente discorrer e verbalizar seus pensamentos, tendências e reflexões sobre os temas apresentados, o que proporciona maior riqueza; (ii) o questionamento é mais profundo e, também mais subjetivo, o que leva ambos a uma relação recíproca de confiabilidade; (iii) freqüentemente, as questões dizem respeito a uma avaliação de crenças, sentimentos, valores, atitudes, razões e motivos acompanhados de fatos e comportamentos; (iv) as questões elas exigem que se componha um roteiro de tópicos selecionados, possuindo formulação flexível, de forma que as seqüências de minúcias ficam por conta do discurso do entrevistado e da dinâmica que acontece naturalmente.

\subsubsection{Descrição das etapas da entrevista}

Com base na revisão da literatura, foi preparada uma síntese dos artigos que deu subsídio para elaboração de perguntas que serviram de roteiro para entrevista semi-estruturada.

As questões preparadas no roteiro são abertas, permitindo ao entrevistado abordar mais de uma característica em sua resposta.

Para orientar o entrevistador ao longo da condução da entrevista, foram definidos pontos essenciais ao debate, de modo a verificar se o entrevistado abordou todas as dimensões consideradas.

Além disso, foram definidas algumas palavras e termos chave para cada questão, 
possibilitando verificar na condução da entrevista a aderência da resposta ao que se propunha medir.

Ainda com relação à confiabilidade do instrumento, o próprio pesquisador atuará como entrevistador em todas as entrevistas realizadas, evitando diferenças pessoais de postura e de forma de condução da entrevista. As entrevistas serão em inglês ou em português.

Os convidados a participar das entrevistas em profundidade foram os gestores dos projetos (gerente geral do projeto) ou pessoas que participam da gestão e do processo decisório em cada uma das iniciativas, o empreendedor social fundador do projeto, parceiros (fornecedores e financiadores) e a população que faz parte dos objetivos da organização: clientes e trabalhadores.

Os gestores estão diretamente ligados ao fundador da organização e trabalham diretamente com as organizações parceiras. Foram entrevistados três gestores (Botsuana, Brasil e Jordânia), o fundador, um fornecedor e parceiros (organização local, jovens surdos profissionalizados, um cliente final usuário e um cliente da fundação humanitária).

As responsabilidades desses gestores incluem: gerir o projeto, assegurar produção, vendas e controle de despesas de acordo com a previsão, preparação de relatórios para a organização que financia o projeto, estabelecer parceiros para distribuição dos produtos, promover novos programas educacionais para os jovens trabalhadores de forma a melhorar suas técnicas, assim como busca de novos investidores e doadores.

O convite à participação das entrevistas foi realizado via correio eletrônico (email), ocasião na qual foram explicados os objetivos da pesquisa e o enfoque da entrevista. Foi solicitada aos entrevistados no momento do convite a permissão para gravação da entrevista para uso da autora com finalidades exclusivamente acadêmicas.

As entrevistas foram marcadas para meados de Abril 2011 até início de Junho 2011 e parte delas foi realizada utilizando-se a tecnologia de vídeo conferência, que permite que as duas pessoas se comuniquem a distância por meio de áudio e vídeo. Duas exceções aconteceram: no caso dos jovens surdos de Botsuana as entrevistas foram feitas via 
questionário escrito enviado via correio eletrônico. Isso se deu, pois cada país tem sua própria língua de sinal e os conhecimentos do pesquisador neste âmbito não estavam ao alcance de uma entrevista via vídeo. No caso do projeto no Brasil, local onde a pesquisa foi desenvolvida, as entrevistas via questionário escrito foram realizadas pessoalmente, com interação entre o entrevistado e entrevistador.

Todas as entrevistas foram transcritas para o processo de análise. Outros documentos necessários foram solicitados à organização no sentido de "corroborar e valorizar as evidências oriundas de outras fontes" (YIN 2003, p. 112).

Durante o processo de análise foi seguido o objetivo da pesquisa, valorizando, portanto, as questões quanto às características de cada iniciativa nas três diferentes localidades, bem como os fatores facilitadores e dificutadores em sua implementação.

Assim, a triangulação de dados, descrita por Yin (2003) como os três princípios para garantir a qualidade dos resultados de uma pesquisa qualitativa, foram levados em conta nesse trabalho e são definidos como: (a) utilização de várias fontes de evidências, e não apenas uma; (b) criação de um banco de dados para o estudo de caso; e (c) manutenção de um encadeamento de evidências.

\subsection{Universo de Pesquisa - Solar Ear}

O objeto de estudo escolhido foi a iniciativa Solar Ear, que por meio da profissionalização e emprego de jovens surdos, faz a montagem de aparelhos auditivos, recarregadores solares e baterias recarregáveis de aparelhos auditivos. Esses produtos são distribuídos a baixo custo principalmente para crianças com deficiência auditiva em países em desenvolvimento. A iniciativa dá acesso a pessoas fisicamente e economicamente excluídas da sociedade, a obterem um produto mais barato que os que estão no mercado e com a inovação tecnológica das baterias solares, além de profissionalizar e empregar jovens surdos que nunca tiveram anteriormente outra oportunidade de trabalho. A iniciativa já possui parceiros com interesse em iniciar atividade em mais de oito países, mas o estudo irá focar apenas naqueles que já estão com a operação em fase de implementação: Botsuana, Brasil e Jordânia. 
A iniciativa Solar Ear, de modo geral, apresenta uma atuação reconhecida por prêmios humanitários internacionais e mídia internacional. Em 2011, a organização foi reconhecida como uma das empresas mais inovadoras do Brasil (Fast Company, 2011). Em 2010 foi convidada para apresentar seu modelo de negócio para o prêmio Nobel Mohammed Yunus, em uma reunião fechada. Em novembro de 2010, fez parte de uma matéria na importante revista National Geografic como uma das invenções eco-brilhantes para solucionar problemas sociais. Em 2009 recebeu o prêmio TechAward juntamente com Al Gore, em 2008 recebeu o prêmio humanitário da American Academy of Audiologist. O fundador passou a ser fellow da Ashoka a partir de 2008 e anualmente ministra apresentações sobre seu trabalho em importantes Universidades e Congressos. A organização possui seus produtos expostos na Samsorian Museum e no Museu Alexander Graham Bell. Todo ano recebe estudantes de diversos países bem como a mídia local, nacional e internacional.

A organização já vendeu produtos para mais de trinta países e hoje tem suas unidades apenas em países pobres, emergentes e/ou em situação de conflito.

\subsubsection{Solar Ear - Botsuana}

Sob o nome de Godisa, o empreendimento foi iniciado em Otse, Botsuana em 2002 e desenvolveu um aparelho auditivo solar analógico atrás da orelha, baterias recarregáveis para aparelho auditivo e o primeiro carregador solar para baterias de aparelho auditivo.

A iniciativa em Botsuana capacitou e contratou doze jovens surdos para a produção de equipamentos eletrônicos. Depois de ganharem experiência de trabalho durante alguns anos, quatro desses jovens receberam uma segunda capacitação com um curso técnico de micro-solda de aviação no Canadá. O curso certificou-os para serem professores em micro-solda.

Godisa tem sete anos de existência e atualmente passa por um processo de transformação legal, através do qual se transforma em uma empresa por lucros de propriedade dos trabalhadores surdos. Eles terão a partir deste ano duas estruturas de precificação: uma para organizações sem fins lucrativos e outra, com valores mais altos, para empresas por lucro. Eles também irão oferecer mais serviços, tais como reparação de produtos 
eletrônicos como rádios.

\subsubsection{Solar Ear - Brasil}

Iniciado em 2009, surgiu com o objetivo de replicar o modelo de sucesso desenvolvido em Botsuana. Utilizando o nome de Solar Ear, o empreendimento foi levado para o Brasil com a parceria de uma ONG que há dez anos atua na área de fonoaudiologia, o Instituto CEFAC.

Através da Lemelson Foundation e o Instituto CEFAC, além de várias partes interessadas de universidades da América Latina e, em conjunto com os empregados surdos do projeto na África (Solar Ear - Botsuana), o Solar Ear - Brasil fabrica e distribui, por toda a América Latina, o primeiro aparelho auditivo digital recarregável do mercado, um novo carregador solar, e baterias recarregáveis de aparelhos auditivos, além de um molde auricular instantâneo.

O Solar Ear Brasil incluiu novos produtos no portfólio e desenvolveu um novo modelo de carregador solar com novas funcionalidades para o usuário, bem como baterias mais potentes.

Foram contratados no início do projeto dez jovens surdos; hoje o projeto tem uma capacidade produtiva de 800 carregadores e aparelhos auditivos por mês.

\subsubsection{Solar Ear - Jordânia}

Iniciou em 2010 e faz parte de uma parceria entre The Canadian International Scientific Exchange Program (CISEPO). Recebeu financiamento da United States Agency for International Development (USAID) e está hoje em fase de implementação, já possuindo uma estrutura gerencial contratada que está desenvolvendo estratégias locais de entrada no mercado. O projeto terá jovens surdos da Palestina, Israel e Jordânia trabalhando juntos. 


\section{ANÁLISE DO ESTUDO DE CASO}

A seguir serão apresentados os resultados da pesquisa feita com a iniciativa Solar Ear. Os dados foram obtidos por meio de levantamento de dados secundários e entrevistas. Documentos como plano de negócios da organização, metas e projeções de vendas, balanço social, contrato social, prestação de contas para financiadores, entre outros foram solicitados separadamente a cada uma das três unidades distribuídas nos diferentes continentes. A entrevista realizada com o fundador da iniciativa teve como principal foco o entendimento do modelo de negócio, as estratégias de mercado, além das motivações para de seu surgimento. As entrevistas feitas com cada um dos gestores teve como objetivo entender como as estratégias são colocadas em prática e compreender as diferenças em cada país. Informações retiradas de dados secundários complementaram a análise da estratégia desta iniciativa.

O roteiro de entrevista bem como o protocolo de pesquisa encontram-se nos anexos do presente trabalho.

Este capítulo está dividido em quatro grandes blocos: Contextualização do problema; Descrição e histórico da iniciativa; Modelo de negócio; Funcionamento do modelo em cada país.

\subsection{Contexto}

De acordo com a organização World Wide Hearing, dados da OMS mostram que pelo menos 642 milhões de pessoas no mundo são afetadas por algum tipo de perda auditiva, $70 \%$ das quais vive em países em desenvolvimento e apenas um de cada 40 deficientes terá a oportunidade de usar um aparelho auditivo. (WWHEARING, 2011).

Um grande impacto social acontece quando a perda auditiva é identificada bem cedo na infância e o indivíduo tem a oportunidade de utilizar um aparelho auditivo. Com a adaptação de um aparelho auditivo em uma criança, é possível observar uma melhora significativa da fala entre outros fatores essenciais para seu desenvolvimento, o que também reduz futuros custos com recursos educacionais especiais (HEAR IT, 2011). Segundo o fundador da iniciativa Solar Ear, existem estudos que mostram que ajudar 
pessoas com deficiência pode aumentar o PIB do país em 3 a $4 \%$.

No Brasil, aproximadamente cinco milhões de pessoas precisam de um aparelho auditivo e apenas 300.000 aparelhos são vendidos anualmente. O sistema de saúde público brasileiro, SUS (Sistema Único de Saúde), foi responsável pela distribuição de 210.000 aparelhos em 2010 (RTS, 2011).

Segundo informações do gestor na Jordânia, na região, incluindo a Faixa de Gaza e os países Irã, Iraque, Israel, Jordânia, Quaite, Líbano, Arábia Saudita, Síria, Emirados Árabes, Palestina, Turquia e Iêmen, o número de pessoas com deficiência auditiva que precisam de um aparelho auditivo chega a 20 milhões, o que representa uma média de aproximadamente $7 \%$ da população.

Segundo o gestor da África, o problema é ainda maior naquela região. Apenas entre as crianças, essa porcentagem varia de $7,5 \%$ na África do Sul a $14 \%$ na Nigéria. Segundo dados da organização Hear-it, (HEAR-IT, 2011), no Quênia, Gâmbia e Tanzânia, cerca de 2,5 a 3,5 crianças a cada 1000 sofrem de perda auditiva severa ou profunda.

Existem cerca de cinco grandes empresas de aparelho auditivos no mundo todo e algumas centenas de produtos de baixa qualidade e baixo preço, produzidos principalmente em países asiáticos.

Ao levar em conta a localidade das grandes indústrias de aparelhos auditivos e de componentes de aparelhos auditivos no mundo, pode-se observar que $90 \%$ delas são de origem norte-americana e européia. Geralmente, as fábricas de aparelhos auditivos em países em desenvolvimento importam todos os componentes e fazem a montagem desses equipamentos localmente. Em alguns casos, importam-se os produtos já montados por essas grandes indústrias e distribuidores realizam o comércio local.

Segundo o fundador da iniciativa Solar Ear, as cinco maiores indústrias produzem anualmente apenas nove milhões de aparelhos auditivos que são distribuidos principalmente para países desenvolvidos. Apenas 12\% deles vão para os países em desenvolvimento, o que significa dizer que o mercado para aparelhos auditivos nestes 
países é de aproximadamente 400 milhões, o que representa uma grande oportunidade de mercado para empresas de aparelho auditivo. De acordo com a fonoaudióloga da unidade no Brasil, um aparelho auditivo com as mesmas especificações de um aparelho do Solar Ear pode ter ser encontrado no mercado por valor seis vezes mais caro que os aparelhos auditivos da iniciativa.

Além do alto custo dos aparelhos auditivos, a grande dificuldade entre deficientes auditivos em regiões pobres e isoladas, é o custo das baterias e a dificuldade de acesso a elas. Segundo informações da organização, uma bateria custa por volta de dois reais e duras em média uma semana ${ }^{14}$, sendo dificilmente encontradas em áreas distantes das grandes cidades. Além disso, em países pobres as organizações humanitárias que doam os aparelhos auditivos, não doam as baterias e o impacto esperado de suas ações acaba não acontecendo, pois os deficientes auditivos deixam de utilizar o aparelho auditivo por falta de acesso às baterias.

Assim, o alto custo do aparelho e da manutenção das baterias é um fator que impede o acesso de pessoas com deficiência auditiva a este produto.

Os aparelhos auditivos tem como característica a necessidade de serem programados segundo a frequência da perda auditiva que a pessoa possui. Ele não é um produto que pode ser distribuido diretamente ao cliente final, precisando portanto de profissionais especializados. Assim, um fator que impede as empresas entrarem no mercado de países em desenvolvimento, é, também, a dificuldade em se encontrar profissionais (audiólogos, fonoaudiólogos, otorrinolaringologistas e protéticos) para realizar as adaptações dos aparelhos auditivos nos indivíduos.

Além de pouco explorado, este mercado tende a crescer, pois segundo o fundador, enquanto houver pobreza no mundo e falta de acesso a informações sobre prevenção, existirá o problema da deficiência auditiva.

\footnotetext{
${ }^{14}$ Segundo o fundador da iniciativa Solar Ear, atualmente 200 milhões de baterias de aparelho auditivo são descartadas anualmente. Uma bateria recarregável tem duração de dois a três anos, enquanto uma bateria descartável dura uma semana. Assim, a iniciativa apresenta uma proposta de alto impacto ambiental.
} 


\subsection{Surgimento da iniciativa e histórico}

Pode-se dizer que no caso do Solar Ear, existiram dois fatores que determinaram seu surgimento.

O primeiro foi o fato do presidente de uma grande empresa no Canadá, que ao perder sua filha de onze anos em uma morte inesperada e, em seguida, perder seu cargo na presidência da empresa em que trabalhava, decide partir para África, Botsuana, para fazer um trabalho humanitário. Sua motivação pessoal ao chegar a Botsuana foi reforçada ao encontrara uma criança africana surda com o mesmo nome e nascida no mesmo dia, mês e ano que sua filha. Ela solicitou ajuda para conseguir um novo aparelho auditivo para dar continuidade aos seus estudos.

O segundo fator foi uma ONG africana que não tinha dinheiro, produtos ou empregados, mas que possuía um projeto de produção de aparelhos auditivos a baixo custo produzidos por pessoas surdas. Essa organização estava buscando um administrador para dar viabilidade econômica e levantar recursos para o projeto.

Assim, o surgimento da iniciativa Solar Ear se deu ao associar a necessidade ou demanda não atendida de uma organização, com a oferta e disponibilidade de alguém capacitado e fortemente engajado em ajudar a desenvolver um negócio de grande impacto social.

O fundador da iniciativa afirmou que antes de propor uma solução para o problema da deficiência auditiva, estudou relatórios da Organização Mundial de Saúde, os quais indicavam que, além do alto custo dos aparelhos auditivos, a grande dificuldade entre deficientes auditivos em regiões pobres e isoladas, era o acesso às baterias e seu custo. Ao perceber que a própria população de deficientes auditivos daquela comunidade deixava de utilizar o aparelho auditivo por falta de acesso às baterias, o fundador chamou um grupo de jovens surdos para ajudar no desenvolvimento de um produto que solucionasse este problema.

Assim, os próprios jovens surdos da cidade de Otse em Botsuana, principalmente aqueles que possuíam aparelhos auditivos e não os usavam por falta de acesso e alto custo das baterias, foram essesnciais no momento de criação dos produtos e da implementação da 
iniciativa.

A implementação e o desenvolvimento dos produtos aconteceu com a busca de parceiros que estavam dispostos a treinar as pessoas surdas para fabricar aparelhos auditivos.

Em sua primeira tentativa, encontrou-se um fabricante de aparelhos auditivos europeu, porém a parceria não perdurou, pois sua missão era apenas o lucro e não trazia grandes benefícios para os jovens, que se viram explorados com a proposta.

Para desenvolver os produtos de forma autônoma, o fundador da iniciativa juntamente com os jovens surdos, desenvolveram uma inovação tecnológica que permitiu resolver o problema das baterias: a criação de um carregador solar para baterias de aparelho auditivo e baterias recarregáveis. Para isso, ele se locomoveu até a capital da África do Sul e encontrou a infra-estrutura que precisava.

Assim, o desenvolvimento do projeto do carregador foi feito por um engenheiro da África do Sul, mesma localidade onde foram produzidos os plásticos e os componentes eletrônicos. A aparência (design) do produto foi decidida de forma participativa pela população surda envolvida na iniciativa. Em seguida, o fundador entrou em contato com fornecedores de painéis solares na Ásia, onde encontrou o atual fornecedor, que possuía um produto que atendia às especificações necessárias.

No caso das baterias de aparelho auditivo, o fundador da iniciativa partiu de uma lista de 75 diferentes produtores, desde baterias para relógios até baterias padrão como a AA ou a AAA. Esses produtores receberam uma carta explicando a missão social de sua iniciativa. Segundo o fundador, apenas 15 produtores retornaram dizendo que seria possível cooperar de alguma forma, mas apenas dois aceitaram produzir as baterias recarregáveis. Um deles foi descartado, pois o pedido mínimo seria de alguns milhões de unidades, o que seria inviável. $\mathrm{O}$ fornecedor que aceitou fornecer as baterias investiu em ferramentas e moldes sem repassar os custos para o preço final do produto; entendendo que se a iniciativa crescesse, seu faturamento também iria crescer. Assim, para o fundador do Solar Ear, os fornecedores são parceiros do negócio que acreditam na missão social e têm a motivação de crescerem juntos. 
O fundador da iniciativa conseguiu perceber que a própria população surda, que não possuia nenhuma oportunidade profissional poderia servir como mão-de-obra para a produção desses equipamentos.

A escolha em se trabalhar com pessoas surdas foi feita, não apenas como forma de inclusão de pessoas com deficiência no mercado de trabalho, mas principalmente porque, ao se comunicarem através de linguagem de sinais, os surdos utilizam as mãos e por essa razão, desenvolvem sua coordenação motora de forma diferenciada, o que lhes permite, manufaturar produtos de alta precisão com maior qualidade. A qualidade da coordenação motora de pessoas surdas já foi evidenciada por autores como Souza et al (2008).

Quatro jovens africanos surdos foram mandados ao Canadá durante o período de dezoito semanas para realizar um curso de micro-solda de aviação. Este curso lhes capacitou para a produção de equipamentos eletrônicos, incluindo aparelhos auditivos e os carregadores.

Segundo dados secundários disponibilizados pela iniciativa, um especialista em microsolda de aviação afirmou que a solda feita nos produtos comercializados pelo Solar Ear pode ser considerada como "uma solda com parâmetros militares, muito próximos aos parâmetros da NASA". ${ }^{15}$

Para que o Solar Ear entrasse no mercado de aparelhos auditivos, a iniciativa não contou apenas com a inovação tecnológica do carregador solar e das baterias recarregáveis. Diferentemente da maior parte dos aparelhos auditivos, ela desenvolveu seus produtos com trimmers, isto é, regulagens manuais que são configuradas por fonoaudiólogos no próprio usuário, ao invés de softwares instalados em um computador. Desta forma, os fonoaudiólogos podem fazer a adaptação do aparelho, mesmo em áreas pobres onde não haja nenhuma infra-estrutura de computadores ou mesmo energia elétrica.

Assim, a organização Solar Ear surgiu com o propósito de profissionalizar jovens surdos para produção de aparelhos auditivos recarregáveis por energia solar que são vendidos a

15 "If I had to rate it I would say it is at military standard very close to NASA standards!" André Baune, especialista em micro-solda de aviação. 
um preço acessível a pessoas com deficiência auditiva em países em desenvolvimento.

Pelo caráter inovativo e a qualidade de seus produtos, a iniciativa foi reconhecida internacionalmente por manifestações que vão desde citações em revistas de grande circulação até o recebimento de prêmios humanitários.

Atualmente a iniciativa está presente em três países: Botsuana, Brasil e Jordânia. Duas unidades comercializam produtos, Brasil e Botsuana, e a terceira está em fase de implementação na Jordânia.

A iniciativa Solar Ear funciona como um projeto alocado dentro de organizações já existentes (ou criadas para tal objetivo) em cada país.

Em Botsuana, na cidade de Otse, onde foi criada a unidade pioneira do negócio inclusivo Solar Ear, o projeto se iniciou dentro de uma comunidade de surdos que tinha apoio de uma ONG internacional. Para abrigar a iniciativa Solar Ear, criou-se uma organização local chamada Godisa.

Segundo o fundador, as unidades que foram criadas após a primeira experiência na África surgiram de pessoas que pediram a ele que explicasse o modelo e transferisse a tecnologia. Inicialmente, não havia a ambição de ampliar o negócio.

A unidade do Brasil iniciou em uma organização no interior de São Paulo, mas após muitos entraves, outra ONG brasileira fez o convite para que o empreendedor social, fundador da iniciativa em Botsuana, implementasse o negócio em São Paulo. Assim, a nova unidade surgiu formalmente no Brasil, como uma filial do Instituto CEFAC, que na época já possuía nove anos de experiência de voluntariado na área da fonoaudiologia.

A unidade de Botsuana e do Brasil surgiram devido ao grande interesse local de desenvolver a missão social da iniciativa, isto é, ambas as organizações locais tinham interesse em desenvolver aparelhos auditivos de baixo custo para beneficiar as próprias comunidades nas quais elas já estavam atuando.

No caso do Oriente Médio, o surgimento da iniciativa se deu por meio do interesse de 
uma organização canadense CISEPO, que tinha acesso a recursos para financiar um projeto que relacionasse saúde e paz entre israelenses, palestinos e jordanianos. Assim, a organização escolheu o Solar Ear como iniciativa para desenvolver essa missão social. O objetivo seria a contratação de jovens surdos das três diferentes origens para trabalharem juntos produzindo aparelhos auditivos solares. Com o apoio do príncipe da Jordânia, o projeto inicialmente seria implementado em uma ONG local, mas por problemas de conflito de interesses interno, os recursos investidos para implementação tiveram de ser transferidos, por ordem do príncipe e pressão do fundador, para uma segunda organização. A organização escolhida pelos parceiros e que acolheu o projeto é um centro de pesquisa e inovação (Royal Scientific Society of Jordan - RSS) que pertence ao governo da Jordânia e que, até o momento, não atuava na área da audiologia.

Assim, a unidade em Botsuana, quando de sua implementação se chamava Godisa (atualmente, Deaftronics); no Brasil, Instituto CEFAC e na Jordânia, Royal Scientific Society.

A seguir, apresenta-se um resumo do surgimento de cada uma das iniciativas.

\section{Quadro 5 - Surgimento da iniciativa}

\begin{tabular}{|c|c|c|c|}
\hline & Botsuana & Brasil & Jordânia \\
\hline $\begin{array}{l}\text { Ano de } \\
\text { surgimento }\end{array}$ & 2002 & 2009 & 2010/2011 \\
\hline $\begin{array}{l}\text { Recursos } \\
\text { financeiros }\end{array}$ & $\begin{array}{l}\text { próprios do fundador e } \\
\text { doações }\end{array}$ & fundação americana & $\begin{array}{l}\text { ONG canadense e } \\
\text { outras fundações }\end{array}$ \\
\hline $\begin{array}{l}\text { Inovação } \\
\text { social }\end{array}$ & $\begin{array}{l}\text { desenvolveu } \\
\text { fornecedores, produziu } \\
\text { carregador solar, } \\
\text { baterias e 1ㅇaaho } \\
\text { auditivo }\end{array}$ & $\begin{array}{l}\text { aprimorou o carregador } \\
\text { solar e desenvolveu } \\
\text { novos modelos de } \\
\text { aparelho auditivo }\end{array}$ & - \\
\hline $\begin{array}{l}\text { Parceiros } \\
\text { locais }\end{array}$ & $\begin{array}{l}\text { ONG internacional } \\
\text { atuando localmente }\end{array}$ & ONG local & $\begin{array}{l}\text { Centro de pesquisa e } \\
\text { apoio da família real }\end{array}$ \\
\hline $\begin{array}{l}\text { Missão } \\
\text { específica }\end{array}$ & $\begin{array}{l}\text { redução do índice de HIV } \\
\text { entre surdos }\end{array}$ & $\begin{array}{l}\text { desenvolvimento de } \\
\text { comunicação oral entre } \\
\text { os surdos }\end{array}$ & $\begin{array}{l}\text { Paz entre israelenses, } \\
\text { jordanianos e } \\
\text { palestinos }\end{array}$ \\
\hline
\end{tabular}

$\underline{\text { Missão }}$

A missão da iniciativa é a prevenção e a redução do impacto da deficiência auditiva na 
vida das pessoas. O resultado que se espera com essa missão é a transformação de pessoas marginalizadas (ou potencialmente marginalizadas) pela deficiência auditiva, em cidadãos ativos na sociedade e uma transformação da própria sociedade.

Esse resultado, segundo dados disponibilizados pela iniciativa, se dá por meio: (i) da possibilidade de acesso de pessoas com perda auditiva aos aparelhos auditivos, principalmente crianças abaixo de três anos de idade, que com o uso do aparelho auditivo desde pequena, poderiam desenvolver a comunicação oral tornando-se indivíduos mais independentes; (ii) do emprego de pessoas surdas, melhorando sua auto-estima, desenvolvendo uma profissão e crescimento de carreira; (iii) da mudança de conceitos e padrões da sociedade ao ver que uma pessoa deficiente pode trabalhar profissionalmente com a mesma eficiência e qualidade de uma pessoa não deficiente.

Além da missão geral da iniciativa, cada país tem sua missão específica, permitindo um envolvimento maior dos surdos com a organização. Em Botsuana, a missão específica é a redução do índice de HIV/ AIDS entre os jovens surdos; no Brasil é o desenvolvimento da comunicação e terapia da fala entre os surdos e no Oriente Médio é propagação da paz, por meio do trabalho de jovens surdos israelenses, palestinos e jordanianos juntos.

\subsection{Modelo de Negócio}

\section{$\underline{\text { Atividade organizacional }}$}

A organização Solar Ear se propõe a profissionalizar jovens surdos para produção de aparelhos auditivos recarregáveis por energia solar que são vendidos a um preço acessível a pessoas com deficiência auditiva em países em desenvolvimento.

Assim, em cada um dos países onde está presente, são realizadas três principais atividades: capacitação, produção e comercialização.

A capacitação consiste em um treinamento técnico dos jovens surdos e o acompanhamento desses em um processo de profissionalização. O treinamento técnico é um curso prático e teórico de micro-solda eletrônica, de duração de três a cinco meses, ministrada por surdos de outra unidade. Os próprios trabalhadores surdos de um país são 
os professores dos surdos de outra unidade. Os professores surdos passam por um período de adaptação, onde aprendem a nova linguagem de sinal, dado que cada país tem seus próprios sinais para o alfabeto e para o vocabulário.

O treinamento técnico apresenta uma inovação no aspecto da inclusão dos trabalhadores surdos que desenvolvem os produtos. Aqueles que se destacam dos demais são escolhidos e treinados para serem professores, tendo a oportunidade de ensinar a profissão a novos trabalhadores surdos de outros países. Esta capacitação consiste em uma significativa inovação que se diferencia dos padrões de treinamento de outras empresas, pois é uma forma de reconhecimento e de crescimento na carreira para os trabalhadores surdos.

Segundo o fundador do projeto, esse treinamento faz parte da missão social, pois permite que os jovens trabalhadores tenham a oportunidade de crescer dentro da sua carreira de técnico em eletrônica e dentro da própria iniciativa. Ao mesmo tempo, os novos alunos surdos já iniciam sua carreira quebrando paradigmas, pois geralmente, os professores de escolas de surdos são ouvintes, sendo este o primeiro contato com professores que, como eles, são surdos.

Depois da capacitação técnica os jovens surdos se profissionalizam por meio da produção de equipamentos eletrônicos. Dentro de cada unidade é feita a montagem de aparelhos auditivos e carregadores solares e são embaladas as baterias.

A organização faz a montagem e comercializa quatro tipos diferentes de aparelhos auditivos, um carregador solar e três tipos diferentes de baterias recarregáveis para aparelhos auditivos. O carregador solar, bem como as baterias recarregáveis para aparelhos auditivos representam uma inovação tecnológica no mercado.

A comercialização segue a proposta da venda de aparelhos auditivos por um preço, em média, dez vezes menor dos que estão no mercado, porém com a mesma qualidade dos cinco maiores fabricantes ${ }^{16}$ e ainda, apresenta um diferencial para o mercado que é a

\footnotetext{
${ }^{16}$ Durante a pesquisa de dados secundários, encontrou-se um estudo que comparava qualidade e preço entre os aparelhos do Solar Ear e outros equivalentes no mercado. Como resultado do estudo apresentou-se
} 
possibilidade de se utilizar baterias recarregáveis com vida útil de até três anos. Essas baterias também podem ser usadas em aparelhos auditivos de qualquer outro fabricante, desde que o tamanho seja compatível.

Cada unidade é responsável pela sua venda local e alguns grandes clientes globais é prospectado pelo fundador. As duas operações do Solar Ear que atualmente comercializam produtos têm um alcance geográfico de 31 países. Apesar do objetivo final ser a distribuição dos produtos para países em desenvolvimento, algumas vezes organizações humanitárias de países da Europa e dos Estados Unidos compram os produtos para doarem a instituições em países pobres. Atualmente o Solar Ear não pode comercializar seus produtos no Brasil, pois ainda depende de licenças de órgãos da vigilância sanitária, mas comercializa em grande parte dos países da América Latina, onde possui distribuidores ou clientes de organizações humanitárias.

Não faz parte da proposta do Solar Ear vender aparelhos auditivos para o cliente final, visto que é necessário fazer a adaptação do aparelho com um profissional especializado. Assim, os produtos do Solar Ear são vendidos para: (i) seus distribuidores (profissionais na área da audiologia); (ii) organizações sem fins lucrativos de caráter humanitário, que doam o produto, geralmente para escolas de surdos e hospitais em áreas rurais, fazendo o produto chegar até pessoas muito pobres; e (iii) órgãos do governos, que distribuem para hospitais da rede pública.

Apesar da iniciativa ter seu posicionamento de mercado no público de baixa e média renda, principalmente crianças, seus produtos competem também com as grandes empresas de aparelho auditivo que atendem apenas clientes de classe A e B.

\section{$\underline{\text { Pilares do modelo }}$}

A cada nova unidade que surge, o fundador enfatiza que é necessário cumprir alguns prérequisitos e observar alguns procedimentos para não ter dificuldades durante a implementação: (i) formalização de uma parceria local forte e que já atue com 
populações excluídas, de preferência surdos; (ii) contratação de uma equipe gestora, principalmente um gerente geral $^{17}$ que é responsável por todas as atividades do projeto; (iii) criação de uma organização formal para implementação da iniciativa, de preferência uma organização sem fins lucrativos e, caso não seja, que desenvolva um contrato em que a prioridade seja o cumprimento da missão social e que o lucro seja reinvestido na iniciativa; (iv) alocação das atividades em um espaço físico, de preferência isolado de outros projetos que a organização venha a ter, devido ao processo produtivo; (v) disponibilidade dos recursos financeiros necessários para dar início às atividades, principalmente que parte desses recursos, isto é, $\mathbf{2 0 \%}$, seja do próprio parceiro local; (vi) seleção e capacitação das pessoas surdas por meio de um intercâmbio entre os surdos de outras unidades do Solar Ear; (vii) contratação de um professor de comunicação, que é responsável pelo desenvolvimento profissional e pessoal dos trabalhadores surdos, servindo de conexão entre a equipe de gestão e a produção.

Do ponto de vista da gestão, possuir uma parceria local forte é positiva e relevante, pois a iniciativa utiliza o know-how de uma organização já instalada, o que representa redução do período de aprendizagem e maiores oportunidades de sucesso. A contratação de uma equipe gestora e a criação de uma organização formal com espaço físico isolado são essenciais para o desenvolvimento de uma gestão profissional, questão já muito debatida em organizações do terceiro setor. Com relação aos recursos financeiros, a exigência de que parte dos recursos venha do parceiro local pode gerar uma relação saudável de propriedade, responsabilidade patrimonial e governança, fatores essenciais em negócios sociais. Estes fatores podem ser levados em conta e testados em outros negócios inclusivos.

Por fim, os dois últimos fatores se relacionam com a missão da iniciativa e apresentam-se como facilitadores para o cumprimento da missão desta iniciativa específica. Segundo o fundador, em casos onde não houve a presença do professor de comunicação, a autoestima dos jovens surdos foi pouco trabalhada e, conseqüentemente, a motivação

\footnotetext{
${ }^{17}$ Segundo o fundador, o gerente deve ter formação e experiência na área de gestão e se possível formação e/ou experiência complementar na área social, ter viajado para diferentes países para entender suas diferentes realidades e, sobretudo, estar motivado a ajudar pessoas que estejam em situação de risco.
} 
diminuiu. Além disso, muitos problemas de gestão podem existir pela falta de comunicação entre a produção e equipe de gestão.

Em contrapartida à essas exigências, são de responsabilidade do fundador e, no futuro, de uma possível matriz, as seguintes atividades: (i) auxiliar na captação dos outros $\mathbf{8 0 \%}$ dos recursos financeiros necessários para iniciar uma nova unidade; (ii) realizar controle de qualidade dos produtos; (iii) implementar estratégia de marketing global; (iv) emitir pedido de compra junto aos fornecedores; (v) formalização de contratos de parcerias globais; (vi) planejamento estratégico; (vii) desenvolvimento de novos produtos.

A seguir, um resumo das exigências para dar início a cada nova unidade e a contrapartida da organização.

\section{Quadro 6 - FCS: Pilares e contrapartida da organização}

\begin{tabular}{|c|c|}
\hline Cada unidade deve: & Fundador ou possível matriz deve: \\
\hline $\begin{array}{l}\text { Encontrar um parceiro local forte e que já } \\
\text { atue com populações excluídas, de } \\
\text { preferência surdos }\end{array}$ & $\begin{array}{l}\text { Auxiliar na captação dos outros } \mathbf{8 0 \%} \text { dos } \\
\text { recursos financeiros necessários para iniciar } \\
\text { uma nova unidade }\end{array}$ \\
\hline $\begin{array}{l}\text { Contratar equipe gestora, responsável pelas } \\
\text { atividades do projeto }\end{array}$ & Garantir controle de qualidade dos produtos \\
\hline Criar organização formal, lucro reinvestido & Implementar estratégia de marketing global \\
\hline $\begin{array}{l}\text { Designar um espaço físico, de preferência } \\
\text { isolado de outros projetos que a organização } \\
\text { venha a ter, devido ao processo produtivo }\end{array}$ & $\begin{array}{l}\text { Emitir pedido de compra junto aos } \\
\text { fornecedores }\end{array}$ \\
\hline $\begin{array}{l}\text { Levantar recursos financeiros sendo } 20 \% \text { do } \\
\text { parceiro local }\end{array}$ & $\begin{array}{l}\text { Formalização de contratos de parcerias } \\
\text { globais }\end{array}$ \\
\hline Selecionar e capacitar (de surdo para surdo) & Planejamento estratégico \\
\hline $\begin{array}{l}\text { Professor de comunicação, desenvolvimento } \\
\text { individual dos surdos }\end{array}$ & $\begin{array}{l}\text { Desenvolvimento de novos produtos, } \\
\text { mesmo que em parceria com as unidades }\end{array}$ \\
\hline
\end{tabular}

Sobre a estrutura organizacional e a relação entre cada uma das unidades nos três países hoje existentes, foi possível depreender que elas são autônomas e não respondem a uma estrutura hierárquica com uma matriz. Não existe, portanto, uma estrutura formal matrizfilial. Em geral, as unidades possuem um elo que se dá por meio da figura do fundador, que atualmente se encontra no Brasil. Sendo assim, o fundador é o grande vínculo entre as unidades, dando suporte para que elas continuem existindo, bem como criando novas. 
Para ele, o conceito mais próximo de organização que se assemelha ao esse modelo de negócio seria o de franquias, porém atualmente ainda não há o recurso suficiente para a criação de uma matriz e de uma estrutura de franqueadas.

Chama a atenção, a falta de um sistema de governança onde estariam inclusas a prestação de contas, a criação de um conselho e auditorias.

Segundo o fundador, atualmente o sistema de governança do Solar Ear está relacionado com a missão e os requerimentos dos financiadores, que possuem protocolos específicos que devem ser seguidos. Apesar das exigências dos financiadores permitir a criação de relatórios periódicos pela organização, não há a existência de um sistema que garanta a accountability e transparência. Nenhuma das três unidades tem divulgado relatórios em seu site, elas apenas têm cumprido exigências dos financiadores.

A tendência de organizações sem fins lucrativos fazerem relatórios que atendem apenas a um dos stakeholders já foi identificada por Najam (1996). O autor afirma que as ONGs devem reconhecer a existência de complexas camadas da accountability para que possam "criar mecanismos e estrutura organizacional que seja igualmente responsável para seus superiores, clientes e para os próprios membros da organização"(NAJAM, 1996, p. 352).

\section{Análise estratégica da iniciativa: facilitadores na implementação}

Conforme anteriormente descrito, a análise da cadeia de valor relacionada ao ecossistema é essencial para a análise estratégica de um modelo de negócio de negócios inclusivos.

Segundo o modelo de Reficco e Vernis (2010), representada na figura 2 deste trabalho, e do modelo teórico desenvolvido no capítulo 2, para que seja possível fazer a análise estratégica de empresas inclusivas serão necessários analisar os seguintes elementos:

(i) Cadeia de valor, incluindo: Inovação tecnológica; Melhoria de produtos; Desenvolvimento de novos produtos - Marketing; Posicionamento do produto no mercado (preço, qualidade); Barreiras enfrentadas pela população envolvida; Parcerias (internas e externas); Estrutura da cadeia de suprimento; Gestão de pessoas e Cultura organizacional; 
(ii) Inclusão social, incluindo: Trabalhadores; Participação da população envolvida; Diferencial que o torna negócio inclusivo

Com relação à inovação tecnológica em negócios inclusivos, pode-se perceber que assim como um negócio tradicional, uma inovação nos produtos sempre pode gerar oportunidade de maior receita.

Para que o Solar Ear entrasse no mercado de aparelhos auditivos, a iniciativa não contou apenas com a inovação tecnológica do carregador solar e das baterias recarregáveis, mas também com aparelhos auditivos com trimmers (regulagens manuais que são configuradas por fonoaudiólogos no próprio usuário, ao invés de softwares instalados em um computador), que facilita a adaptação do aparelho em regiões onde não há infraestrutura.

Além disso, existe a busca por aprimorar os produtos que já possui, ou ainda, desenvolver aparelhos auditivos novos para pessoas ainda excluídas do mercado.

Para fazer melhorias nos produtos, o gestor no Brasil afirma que é relativamente fácil, pois sempre está em contato com os clientes que, algumas vezes, sugerem melhorias que a iniciativa tenta seguir. O processo é entender a sugestão ou reclamação e entrar em contato com o fornecedor solicitando as modificações. Os fornecedores por serem parceiros da iniciativa, na maior parte das vezes acabam fazendo as modificações que são solicitadas, seguindo a lógica de que se a iniciativa vende mais, eles irão vender mais.

No caso de desenvolvimento de novos produtos, o fundador busca parcerias com universidades e centros de tecnologia. Para cada projeto de novo produto deve-se buscar novos recursos com fundações ou nas próprias universidades. Além disso, o desenvolvimento de novos produtos fica a cargo do próprio fundador e não das unidades.

O fato dos gestores das unidades não participarem do desenvolvimento de novos produtos pode ser analisado como um aspecto negativo do modelo de negócio, pois muitas vezes diferentes populações possuem necessidades específicas.

Apesar das diferenças, algumas similaridades na população puderam ser encontradas. 
Segundo entrevista feita com os gestores dos projetos em cada um dos três países, Botsuana, Brasil e Jordânia, pode-se depreender que naqueles países, as barreiras enfrentadas pelos deficientes auditivos são: (i) dependência dos familiares para adquirir um aparelho; (ii) dependência do governo em se fazer doações via sistemas público de saúde; (iii) dependência de organizações sem fins lucrativos que fazem doações desses produtos; (iv) necessidade de profissionais que realizem teste audiométrico e façam adaptações dos aparelhos auditivos conforme a perda auditiva; (v) necessidade de um protético que faça os moldes auriculares; e (vi) para os casos mais severos, necessidade terapia da fala e da voz após a adaptação de um aparelho auditivo.

Para reduzir algumas dessas barreiras, a iniciativa está desenvolvendo: (i) em parceria com o Massachusetts Institute of Technology (MIT), centro de referência em tecnologia nos EUA, um aparelho auditivo sem prescrição, isto é, sem a necessidade de um profissional especializado para fazer a adaptação; (ii) em parceria com uma empresa canadense, um molde auricular instantâneo, eliminando a necessidade de um protético; (iii) juntamente com uma empresa alemã, um software para um audiômetro portátil, o que eliminaria a necessidade de uma clínica equipada com uma cabine audiológica para os exames; (iv) parcerias com outras associações que trabalham com as complementaridades de seus objetivos, como por exemplo, a detecção, prevenção e a terapia.

Assim, as parcerias são fundamentais para minimizar custos de transação, melhorar o posicionamento estratégico e obter aprendizagem organizacional. Segundo o fundador da iniciativa, para estabelecer uma relação de confiança entre os atores é necessário tempo e o desenvolvimento de uma proximidade das relações pessoais. A cada novo parceiro, também é criada uma relação de amizade. Para ele, o princípio para manutenção da boa relação das parcerias é a honestidade e a transparência, mesmo em momentos em que problemas acontecem.

$\mathrm{Na}$ visão do fundador, existem dois tipos de parceiros, os internos e os externos. Os parceiros internos são as pessoas que trabalham diretamente na organização. Eles são os principais atores da cadeia. Os parceiros externos são consumidores, investidores ou organizações financiadoras, organizações locais, fornecedores. 
Dentre esses parceiros, é possível observar que alguns deles são atores globais, que se relacionam com cada uma das unidades por meio da figura do fundador. São eles organizações geradoras de redes (exemplo Ashoka), alguns fornecedores e clientes globais. Outros são pequenos fornecedores e clientes locais, que se diferenciam em cada uma das localidades.

Segundo o fundador, não há nenhuma intenção em se estabelecer parcerias com o poder público, pois segundo seus princípios, essas parcerias podem atrasar o processo ou até mesmo pará-lo. Apesar desta afirmação, o principal parceiro da iniciativa na Jordânia é um membro da família real e a organização real de pesquisa: Royal Scientif Society.

Os fornecedores são elementos críticos para a concretização da missão da iniciativa e, segundo o fundador, recebem o mesmo tratamento dado ao melhor consumidor. Eles não são apenas fornecedores, mas sim parceiros, pois desde o início do projeto, investem em novos produtos, ferramentas e equipamentos, sem repassar os custos, acreditando que poderão crescer junto com a iniciativa.

Os pedidos de compra de matéria prima são feitos levando em conta todas as necessidades das três unidades. O próprio fundador é o responsável pelas ordens de compras e tendo o controle centralizado, consegue ter maior ganho de escala. Apesar da unidade na Jordânia ainda não estar na fase de comercialização, já começaram a adquirir matéria prima para compor um estoque e para a fabricação dos primeiros produtos. $\mathrm{O}$ pagamento da ordem é feito separadamente por cada Solar Ear diretamente ao fornecedor ou, conforme o caso, pago pela unidade no Brasil com posterior reembolso. O envio é feito pelos fornecedores, diretamente para cada um dos países.

Se compararmos os produtos do Solar Ear aos produtos do mercado pode-se dizer que seu posicionamento em relação a preço visa atingir os consumidores de baixa a média renda, porém ainda não consegue atingir aqueles que são considerados "base da pirâmide econômica", isto é, aqueles que vivem com menos de um dólar por dia.

Com relação à qualidade, os produtos atualmente no mercado buscam melhorar o conforto e a aparência do usuário, segundo o fundador da iniciativa. Isto significa dizer 
que as marcas que estão no mercado possuem qualidades que não estão apenas ligadas à melhoria da capacidade de ouvir, mas sim relacionadas principalmente ao bem-estar e estética, enquanto que o Solar Ear está preocupado em atender de forma eficiente a necessidade de ouvir do usuário. Ainda com relação à qualidade, o fundador da iniciativa afirma que as principais matérias primas que impactam na qualidade do som são adquiridas dos mesmos fornecedores das grandes empresas do mercado e, após a produção, todos os aparelhos são rigorosamente testados por um equipamento calibrado para esta função.

Uma das principais competências da organização que a torna competitiva no mercado, segundo o fundador da iniciativa, é a contratação de funcionários surdos. As pessoas surdas desenvolvem uma coordenação motora muito melhor do que grande parte das pessoas ouvintes devido a utilização das mãos para se comunicarem na linguagem de sinal, sendo considerados mais habilidosos e eficientes para a micro-soldagem eletrônica.

No âmbito social, o grande diferencial no modelo de negócio desta iniciativa com relação a outras empresas do mercado é o programa de inclusão e o empowerment dos funcionários (capacity building). Um exemplo disso é a contratação de um professor de comunicação que os capacita por meio da criação de condições que permitem aos indivíduos surdos participarem no processo de aprendizagem e adaptação à mudança.

A qualidade da comunicação, bem como a coordenação motora são duas competências fundamentais na seleção dos surdos. Segundo o gestor do projeto no Brasil, muitos dos surdos que se interessam em trabalhar na unidade não são aprovados durante a seleção. $\mathrm{O}$ conhecimento em língua de sinais, bem como a coordenação motora, são essenciais para o treinamento em micro-solda eletrônica, uma vez que o curso é teórico e prático, porém não se requer um nível elevado de educação formal. Segundo a gestora da unidade em Botsuana, apesar de alguns dos jovens surdos não terem estudo, muitos possuem alta capacidade de comunicação e muito boa coordenação visual e motora porque vivem desde crianças em comunidades de surdos.

Segundo o fundador, a cultura organizacional depende da personalidade do gestor e os funcionários se adaptam à forma de liderança do gestor. Assim, se o gestor é mais focado 
em vendas, a cultura organizacional estará voltada para o marketing, se o gestor é uma pessoa mais técnica, a cultura organizacional estará voltada para a tecnologia.

A valorização da população envolvida faz parte da cultura organizacional da iniciativa. Os programas de desenvolvimento (capacity building) faz com que os jovens surdos se desenvolvam como pessoa e profissionalmente. Os colaboradores e funcionários da iniciativa são os seus principais stakeholders, bem como a comunidade de surdos. Cada unidade está aberta para novas idéias vindas desta comunidade, porém é mantido o foco na atividade para que se garanta sempre sua visão e missão.

De maneira geral, uma barreira que deverá ser superada é a questão de divulgação do produto. Segundo o fundador da iniciativa, as principais marcas de aparelho auditivo investem milhões de dólares em propaganda, sendo difícil a competição para uma pequena organização. Assim, a iniciativa busca o diferencial do atendimento ao consumidor e conta com a divulgação de seu produto em reportagens que reforçam seu valor social.

O quadro a seguir resume os facilitadores da implementação do negócio inclusivo estudado.

\section{Quadro 7 - Facilitadores na implementação do Solar Ear}

\begin{tabular}{|c|c|}
\hline \multicolumn{2}{|r|}{ Facilitadores na implementação } \\
\hline Inovação tecnológica & $\begin{array}{l}\text { oportunidade de maior receita, carregador solar, baterias recarregáveis e } \\
\text { aparelhos adaptados para regiões sem recursos (eletricidade, computador) }\end{array}$ \\
\hline Melhoria dos produtos & contato com toda a cadeia e parceria com fornecedores \\
\hline $\begin{array}{l}\text { Desenvolvimento de novos } \\
\text { produtos }\end{array}$ & $\begin{array}{l}\text { adaptados a necessidade de populações ainda excluídas (parceria com } \\
\text { universidades) }\end{array}$ \\
\hline $\begin{array}{l}\text { Conhecimento das barreiras } \\
\text { enfrentadas pelos clientes }\end{array}$ & $\begin{array}{l}\text { dependência financeira, necessidade de profissionais, necessidade de terapia } \\
\text { da voz }\end{array}$ \\
\hline Parcerias & $\begin{array}{l}\text { investidores, fornecedores (investem em produtos e equipamentos sem } \\
\text { repassar os custos), organizações locais onde são alocados as unidades, } \\
\text { consumidores (ONGs humanitárias, Governo, profissionais) } \\
\text { - Parceiros Globais - via fundador / futura matriz } \\
\text { - Parceiros Locais - desenvolvido por cada unidade }\end{array}$ \\
\hline Posicionamento & $\begin{array}{l}\text { relação ao preço, ganho de escala nos pedidos; qualidade dos produtos, } \\
\text { mesmos fornecedores das grandes empresas, cumpre a função principal do } \\
\text { produto }\end{array}$ \\
\hline Trabalhadores & $\begin{array}{l}\text { jovens surdos que tem melhor coordenação motora; programa de inclusão e } \\
\text { empowerment }\end{array}$ \\
\hline
\end{tabular}




\subsection{Funcionamento do modelo de negócio}

\section{$\underline{\text { Atividade organizacional }}$}

Dentre as três principais atividades presentes no modelo de negócio (capacitação, produção e comercialização), apenas capacitação foi promovida nas três unidades. No caso de Botsuana, a capacitação aconteceu no início do projeto e não foi necessário desenvolver novo curso, pois os jovens que atualmente participam são os mesmos desde o início do projeto. No Brasil, grande parte dos jovens que participaram da primeira capacitação já deixaram o projeto e atualmente, a unidade realiza o segundo treinamento técnico com onze novos jovens surdos. Segundo gestor da unidade, parte dos jovens que deixaram o projeto foram para a universidade, parte se inseriram no mercado de trabalho em melhores condições de salário e 40 horas semanais. Atualmente, a unidade no Brasil oferece apenas trabalhos de 20 horas semanais. Assim, quando um dos jovens surdos deixa a organização, significa que um desafio maior foi proposto e a organização avalia este aspecto como positivo e atendendo um de seus objetivos, pois insere jovens excluídos no mercado de trabalho. A unidade da Jordânia tem como previsão de finalização da primeira turma de capacitação em outubro de 2011.

No momento da pesquisa, a iniciativa Solar Ear possui duas unidades que produzem e comercializam, Brasil e Botsuana. Segundo o gestor no Brasil, apenas a venda do país atinge trinta e um países, incluindo a região do Oriente Médio. A partir do início da comercialização feita pela Jordânia, as outras unidades deixarão de vender para aquela região. A iniciativa na Jordânia, ainda em fase de implementação, está desenvolvendo os conhecimentos e habilidades dos jovens surdos para produzirem. A previsão de início de produção está para final de 2011.

Segundo a gestora da unidade em Botsuana, durante os dois primeiros anos de implementação, não houve equipe de vendas. Todos os clientes - em sua maior parte organizações humanitárias que adquiriam os produtos para doá-los - foram captados pelo próprio fundador da iniciativa. Em alguns casos, o fundador viajava com o objetivo de desenvolver parcerias em pequenas lojas, mas as vendas não eram representativas se comparadas ao investimento das grandes organizações humanitárias. 
Visto que no Brasil os aparelhos do Solar Ear ainda não podem ser comercializados, pois aguardam o licenciamento da Vigilância Sanitária, foram desenvolvidas parcerias com representantes de vendas de outras marcas de aparelhos auditivos que fazem a venda dos carregadores solares e das baterias uma vez que estas podem ser aproveitadas em outros aparelhos auditivos, desde que o tamanho das baterias sejam compatíveis. A venda via parceiros oferece $40 \%$ de desconto nos produtos e exige a obrigação de vendê-los ao preço máximo estabelecido no website da empresa.

Além disso, a unidade brasileira conta com um agente de vendas remunerado que é responsável pela venda dos produtos em toda a América Latina. Atualmente, um dos maiores clientes desta unidade é uma organização humanitária européia que faz doações desses equipamentos a instituições que ajudam surdos em países da América Latina, como Bolívia, Peru, Paraguai, etc.

Um dos objetivos da unidade no Brasil, ao conseguir as licenças e autorizações para venda no país, é ser um dos fornecedores do sistema público de saúde chamado SUS.

Segundo informações dadas pelo gestor da unidade brasileira, o modelo de negócio no Brasil pode incluir no futuro um distribuidor exclusivo por lucro, fazendo com que haja uma injeção de capital e que as vendas aumentem consideravelmente. Segundo o gestor, o acordo está em vias de concretização, aguardando apenas um parecer dos advogados com relação a um contrato que assegure a continuidade da missão social de levar um produto acessível a consumidores de baixa renda.

De acordo com o gestor na Jordânia, apesar de ainda não haver comercialização dos produtos no país, há a previsão de contratação de representantes de vendas locais e agente de vendas que serão distribuídos por regiões como Rússia, Leste Europeu e Norte da África.

Assim sendo, com base nos três pontos principais da atividade organizacional (capacitação, produção e comercialização) e nas entrevistas feitas com cada um dos gestores de cada país foi possível extrair a seguinte ilustração que resume a situação em cada país. 
Quadro 8 - Atividade Organizacional

\begin{tabular}{|c|c|c|c|}
\hline & Botsuana & Brasil & Jordânia \\
\hline Capacitação & $\begin{array}{l}\text { Sim, mesmos } \\
\text { jovens atuam na } \\
\text { iniciativa }\end{array}$ & $\begin{array}{l}\text { Sim, atualmente com } \\
\text { uma } 2 \text { a capacitação }\end{array}$ & $\begin{array}{l}\text { Sim, atualmente } \\
\text { realizando a } 1 \underline{a} \\
\text { capacitação }\end{array}$ \\
\hline Produção & Sim & Sim & Em breve \\
\hline Comercialização & $\begin{array}{l}\text { Sim, organizações } \\
\text { humanitárias }\end{array}$ & $\begin{array}{l}\text { Sim, via agente de } \\
\text { venda América Latina } \\
\text { e representante de } \\
\text { vendas no Brasil p/ } \\
\text { carregador e } \\
\text { baterias. } \\
\text { Possibilidade de } \\
\text { distribuidor exclusivo }\end{array}$ & $\begin{array}{l}\text { Em breve, } \\
\text { representante de } \\
\text { vendas local e } \\
\text { agentes Russia, } \\
\text { Leste Europeu e } \\
\text { Norte da África }\end{array}$ \\
\hline
\end{tabular}

\section{$\underline{\text { Pilares do Modelo }}$}

Em Botsuana, na cidade de Otse, onde foi criada a primeira unidade do negócio inclusivo Solar Ear, o projeto se iniciou dentro de uma comunidade de surdos que tinha apoio de uma ONG internacional. Alocada no espaço físico já existente para outros projetos, foi criada uma organização sem fins lucrativos para abrigar a iniciativa Solar Ear, que naquele momento se chamava Godisa.

O surgimento se deu pelo grande interesse local em desenvolver aparelhos auditivos de baixo custo para beneficiar a própria comunidade surda local. Foram levantados pela Godisa, 20\% do investimento inicial necessário para a implementação da iniciativa e o fundador buscou organizações internacionais para financiar os outros $80 \%$. Para gerenciar o projeto, contratada uma jovem africana, com formação em gestão e que já atuava em projetos com a comunidade surda. Um conselho diretivo foi criado, no qual grande parte dos participantes eram europeus que atuavam em projetos humanitários naquela região. $\mathrm{O}$ grupo de trabalhadores surdos participaram de uma capacitação em microsolda de aviação de duração de 18 semanas no Canadá, no Centre de Formation Professionnelle pour Personnes Sourdes ou Malentendantes. Não houve a presença de um professor de comunicação, devido a dificuldade de especialistas em liguagem de sinais, porém o próprio fundador, enquanto esteve presente na unidade, atuou diretamente com os jovens surdos, trabalhando a auto-estima e questões como prevenção do HIV/AIDS. 
Após a saída do fundador, no momento em que ele se muda para o Brasil, a gestora deixa a gestão da organização e os jovens surdos se organizaram para criar uma nova empresa por lucros, chamada Deaftronics. Atualmente ela é dirigida pelos próprios surdos e um gerente ouvinte com formação em eletrônica.

No Brasil, a iniciativa iniciou em uma organização no interior de São Paulo, mas após muitos entraves, uma outra organização sem fins lucrativos brasileira fez o convite para que o fundador da iniciativa implementasse o negócio na cidade de São Paulo. Assim, a unidade surgiu formalmente no Brasil em 2009, como uma filial do Instituto CEFAC, que na época já possuía nove anos de experiência de voluntariado na área da fonoaudiologia.

A unidade no Brasil surgiu a partir de um convite da organização local que possuia um grande interesse local de desenvolver a missão social do projeto e beneficiar a comunidade de surdos brasileira. O Instituto CEFAC investiu $20 \%$ do valor inicial necessário para a implementação da unidade e os outros $80 \%$ foram levantados junto a uma fundação americana, Lemelson foundation.

O espaço físico para instalação do projeto foi cedido pelo Instituto CEFAC e a primeira capacitação feita com os jovens vindos de Botsuana aconteceu em meados de 2009.

Nesta época foi contratado uma equipe gestora onde estão presentes uma gerente geral com formação em gestão, uma fonoaudióloga e o próprio fundador. Durante todo o ano de 2009, um professor de comunicação esteve presente para selecionar os participantes da capacitação e para desenvolvê-los pessoal e profissionalmente, dentro de um programa de empowerment (capacity building). Durante o ano de 2010, este trabalho não aconteceu por questões financeiras da unidade, entretanto em 2011, com a capacitação de novos jovens surdos, um novo professor foi contratado e atua diretamente com os jovens uma vez por semana.

No caso da Jordânia, diferentemente das outras unidades, o surgimento se deu por meio do interesse de uma organização canadense CISEPO, que tinha acesso a recursos para financiar um projeto que relacionasse saúde e paz entre israelenses, palestinos e 
jordanianos.

A organização CISEPO convidou o fundador da Solar Ear para desenvolver sua missão social naquela região. $\mathrm{O}$ objetivo seria a contratação de jovens surdos das três diferentes origens para trabalharem juntos produzindo aparelhos auditivos solares. Uma gestora local foi contratada e enviada ao Brasil para ser treinada por duas semanas pelo fundador e pela gestora da unidade brasileira. Com a indicação do príncipe da Jordânia, o projeto inicialmente foi implementado em uma organização parceira local e sem fins lucrativos. Porém, os gestores dessa organização local não tinham o envolvimento suficiente com o projeto para compreender a missão social. Conflitos de interesse interno surgiram, uma vez que os gestores da organização parceira dificultaram o acesso aos recursos e demostraram o interesse em se desvirtuar a missão do projeto de vender produtos de baixo custo. Segundo o fundador, além deste primeiro parceiro local não concordar com a tabela de preço dos produtos, ele não concordou em investir $20 \%$ do recurso financeiro inicial necessário e, ainda, não aceitou realizar a capacitação com jovens surdos vindos da África.

Depois de muitas negociações, por ordem do príncipe e por pressão do fundador, os recursos investidos para implementação da unidade na Jordânia tiveram de ser transferidos desta para uma segunda organização. A organização local escolhida pelo gestor e pela CISEPO foi um centro de pesquisa e inovação, RSS, que pertence ao governo da Jordânia e que, até o momento, não atuava na área da audiologia. Esta organização também não aceitou investir $20 \%$ do valor necessário para a implementação da unidade e atualmente aluga o espaço físico para o projeto. A RSS adotou o Solar Ear como um projeto de seu escopo, não criando, portanto, uma figura jurídica formal para a unidade. Com os recursos alocados na nova organização, os desafios giram em torno de concretizar a missão de trabalharem israelenses, palestinos e jordanianos juntos. Segundo a gestora, para que essa missão seja cumprida deve-se retroceder um passo e criar estruturas locais nos três territórios. Assim, seria possível fazer intercâmbios de cooperação entre os surdos dos três Estados, para só depois tentar a coexistência entre eles. Essa proposta oferecida pela gestora é diferente da que consta no modelo de negócio original, mas segundo o fundador, cada organização tem sua liberdade para testar novas formas, porém todas precisam sempre respeitar os pilares essenciais do 
modelo ${ }^{18}$ de negócio, caso contrário terão grandes chances de falhar.

Ainda na Jordânia, a capacitação em micro-solda eletrônica estava sendo realizada no momento da pesquisa. Até aquele momento, não havia a contratação de um professor de comunicação.

A seguir uma representação resume o funcionamento do modelo quanto aos fatores críticos de sucesso em cada um dos países e na seqüência o cumprimento da compartida feita pela organização.

Quadro 9 - Pilares em cada um dos países

\begin{tabular}{|c|c|c|c|}
\hline & Botsuana & Brasil & Jordânia \\
\hline Parceiro local & $\begin{array}{l}\text { Sim, ONG, comunidade de } \\
\text { surdos }\end{array}$ & $\begin{array}{l}\text { Sim, ONG em } \\
\text { fonoaudiologia }\end{array}$ & Não, parceiro de outra área \\
\hline Equipe gestora & Sim & Sim & Sim \\
\hline $\begin{array}{l}\text { Organização } \\
\text { formal }\end{array}$ & $\begin{array}{l}\text { Sim, Godisa. Atualmente } \\
\text { Deaftronics }\end{array}$ & Sim, CEFAC & $\begin{array}{l}\text { Não, é um projeto dentro } \\
\text { da RSS }\end{array}$ \\
\hline Espaço físico & $\begin{array}{l}\text { Sim, cedido, dividindo com } \\
\text { outros projetos da ONG }\end{array}$ & $\begin{array}{l}\text { Sim, cedido um espaço } \\
\text { exclusivo para a iniciativa }\end{array}$ & Sim, alugado pela RSS \\
\hline $\begin{array}{l}\text { Recursos } \\
\text { financeiros }\end{array}$ & $\begin{array}{l}\text { Sim, } 20 \% \text { local e } 80 \% \text { levantados } \\
\text { com a ajuda do fundador }\end{array}$ & $\begin{array}{l}\text { Sim, } 20 \% \text { local e } 80 \% \\
\text { levantados com ajuda do } \\
\text { fundador }\end{array}$ & $\begin{array}{l}100 \% \text { dos recursos doados } \\
\text { por ONG Internacional }\end{array}$ \\
\hline $\begin{array}{l}\text { Intercâmbio de } \\
\text { surdos }\end{array}$ & $\begin{array}{l}\text { 19 iniciativa. Os jovens se } \\
\text { tornaram multiplicadores }\end{array}$ & $\begin{array}{l}\text { Sim, com jovens de } \\
\text { Botsuana }\end{array}$ & $\begin{array}{l}\text { Sim, com jovens de } \\
\text { Botsuana }\end{array}$ \\
\hline $\begin{array}{l}\text { Professor de } \\
\text { comunicação }\end{array}$ & $\begin{array}{l}\text { Não, porém o fundador atuou no } \\
\text { programa de empowerment }\end{array}$ & Sim & Não \\
\hline
\end{tabular}

${ }^{18}$ Os pilares do modelo são:

I) parceiro local forte que já atue com populações excluídas, de preferência surdos;

II) contratação de uma equipe gestora, principalmente um gerente geral que é responsável por todas as atividades do projeto;

III) criação de uma organização formal para implementação da iniciativa, de preferência uma organização sem fins lucrativos e, caso não seja, que desenvolva um contrato em que a prioridade seja o cumprimento da missão social e que o lucro seja reinvestido na iniciativa;

IV) alocação da iniciativa em um espaço físico, de preferência isolado de outros projetos que a organização venha a ter, devido a complexidade da atividade produtiva;

V) disponibilidade dos recursos financeiros necessários para dar início às atividades, principalmente que parte desses recursos, isto é, $20 \%$, venha do próprio parceiro local, criando uma relação de propriedade e responsabilidade patrimonial;

VI) seleção e capacitação das pessoas surdas por meio de um intercâmbio entre os surdos de outras unidades do Solar Ear;

VII) contratação de um professor de comunicação, que é responsável pelo desenvolvimento profissional e pessoal dos trabalhadores surdos, servindo de conexão entre a equipe de gestão e a produção. 


\section{Quadro 10 - Contrapartida da organização}

\begin{tabular}{|c|c|c|c|}
\hline Fundador ou possível matriz deve: & Botsuana & Brasil & Jordânia \\
\hline $\begin{array}{l}\text { Auxiliar na captação dos outros } \mathbf{8 0 \%} \text { dos recursos } \\
\text { financeiros necessários para iniciar uma nova } \\
\text { unidade }\end{array}$ & \multicolumn{3}{|c|}{ Sim } \\
\hline Garantir controle de qualidade dos produtos & \multicolumn{3}{|c|}{$\begin{array}{c}\text { Não ocorre (apenas o treinamento, mas não } \\
\text { garante a qualidade) }\end{array}$} \\
\hline Implementar estratégia de marketing global & \multicolumn{3}{|c|}{$\begin{array}{l}\text { Ocorre parcialmente (preço, produto, } \\
\text { propaganda) }\end{array}$} \\
\hline Emitir pedido de compra junto aos fornecedores & \multicolumn{3}{|c|}{ Sim, ganho de escala } \\
\hline Formalização de contratos de parcerias globais & \multicolumn{3}{|c|}{ Sim, novas tecnologias } \\
\hline Planejamento estratégico & \multicolumn{3}{|c|}{ Focado em desenvolver matriz } \\
\hline $\begin{array}{l}\text { Desenvolvimento de novos produtos, mesmo que } \\
\text { em parceria com as unidades }\end{array}$ & \multicolumn{3}{|c|}{ Sim } \\
\hline
\end{tabular}

\section{$\underline{\text { Análise da estratégia: facilitadores e dificultadores na implementação }}$}

As primeiras dificuldades encontradas durante a implementação em Botsuana foram as mesmas de qualquer outra organização que inicie um negócio em uma cidade de seis mil habitantes no interior de um país da África.

Problemas relativos à infra-estrutura, como acesso à matéria prima, fornecedores, energia elétrica foram os primeiros desafios enfrentados.

Em seguida, teve-se de superar diferenças culturais, como por exemplo, mudar, na própria população africana, a concepção de superioridade da raça branca, bem como o preconceito e desrespeito de alguns dos membros do conselho diretivo com relação à gestora, pelo fato de ser uma mulher, negra e africana.

Outro desafio durante a implementação foi solucionar os conflitos entre gestores, trabalhadores surdos e conselho diretivo. Segundo a gestora da organização em Botsuana, após alguns anos de atuação, ficou evidente a falta de transparência dos diretores com relação ao uso dos recursos financeiros, o que dificultou a continuidade do projeto naquele formato. 
Do ponto de vista da legislação, pode-se perceber que em Botsuana a legislação é fraca com relação a organizações sem fins lucrativos. Assim, não há exigência legal com relação divulgação de resultados, não há nenhum impedimento para que uma organização sem fins lucrativos obtenha receita de venda de produtos e não há também uma regulação que dificulte a produção e venda de equipamentos médicos, como os aparelhos auditivos.

Segundo análise dos dados, a organização na África ainda enfrenta dificuldades de atingir sua sustentabilidade. Um entrave interno em Botsuana e que também afeta a rentabilidade econômica é a questão da governança do conselho diretivo, já citada anteriormente. Mas analisando fatores externos, pode-se propor como hipótese a esse fato dois motivos principais: (i) o baixo poder de compra individual da população africana, pois os produtos comercializados pela unidade, apesar de algumas centenas de vezes mais barato do que os produtos concorrentes, ainda são caros se considerar o poder aquisitivo médio de uma família nas áreas rurais africanas; (ii) a falta de profissionais capacitados para fazer a adaptação dos aparelhos auditivos e preparação dos moldes auriculares.

No Brasil, durante a implementação, a organização tem enfrentado diversos desafios relacionados à burocracia, que ameaça e dificulta a inovação e a busca por novas formas de captação de recursos. Os problemas vão desde a dificuldade de importação, por ser uma associação sem fins lucrativos, até mesmo a obtenção da mais importante certificação da vigilância sanitária para comercialização do produto. Assim, pode-se dizer que esta é a principal barreira que tem dificultado a organização atingir seu mercado, porém, uma vez cumpridas todas as exigências burocráticas, essa barreira deixará de existir.

Do ponto de vista da legislação brasileira, pode-se dizer que há uma complexidade maior com relação às exigências. Entretanto, analisando documentos preparados pelos advogados da unidade no Brasil, pode-se perceber que há uma necessidade de leis que tratem de negócios sociais e negócios inclusivos, visto que, questões como, receita financeira gerada por associações e fundações, consideradas no país como organizações sem fins lucrativos, ainda causam discussões polêmicas e conclusões contraditórias.

Atualmente, a unidade no Brasil não pode comercializar os aparelhos auditivos no país, 
pois aguarda certificação de órgão da agência sanitária há quase dois anos. Além disso, a dificuldade de acesso a informações e os altos impostos são fatores que prolongam o atingimento de seus objetivos de auto-sustentação financeira.

De acordo com o gestor no Brasil, com todas as complexidades de arranjos regulatórios, é necessário que a organização seja muito transparente e correta. Além disso, a reputação para captar recursos internacionais para novas unidades depende de transparência e governança das organizações anteriores.

No caso da Jordânia, os problemas iniciais com relação a governança já foram superados, porém a demora para encontrar uma solução, gerou um atraso no início da capacitação dos jovens surdos e os custos mensais como salários continuaram a incorrer. Um dos principais pontos que chama a atenção no caso da Jordânia, é o fato da unidade não ter seguido parte os pilares do modelo de negócio. Segundo o fundador, não seguir os pilares do modelo pode gerar problemas que impeçam a continuidade da ação. Além disso, a situação se torna mais complexa pelo fato do acompanhamento do fundador ser feito à distância (diferentemente de Botsuana e Brasil, onde o fundador esteve presente durante os primeiros anos de implementação). Finalmente, pode-se observar que a Jordânia apresenta alguns entraves regulatórios como os do caso brasileiro.

\section{$\underline{\text { Análise da estratégia: cadeia de valor }}$}

Conforme autores como Reficco e Vernis (2010), ao analisar as características de um negócio inclusivo, devem ser observados aspectos da cadeia de valor da organização pivô, bem como a interação com outros atores do ecossistema.

Para resumir o que já foi apresentado neste capítulo, propõe-se a seguir um breve quadro que aponta os principais aspectos da cadeia de valor em cada uma das unidades. 
Quadro 11 - Cadeia de valor nas três unidades

\begin{tabular}{|c|c|c|c|}
\hline & Botsuana & Brasil & Jordânia \\
\hline $\begin{array}{l}\text { Fornecedores } \\
\text { (globais e locais) }\end{array}$ & \multicolumn{3}{|c|}{$\begin{array}{l}\text { Mesmo fornecedor internacional para todas unidade e pequenas partes } \\
\text { com fornecedores locais }\end{array}$} \\
\hline $\begin{array}{l}\text { Infra-estrutura da } \\
\text { Organização }\end{array}$ & \multicolumn{3}{|c|}{$\begin{array}{l}\text { Inicialmente é a mesma, pode crescer de acordo com } \\
\text { desenvolvimento de cada unidade local }\end{array}$} \\
\hline Gestão de RH & $\begin{array}{l}\text { Decisões feitas pelo } \\
\text { Conselho } \\
\text { deliberativo, } \\
\text { atualmente segue } \\
\text { modelo de } \\
\text { cooperados, com os } \\
\text { surdos a frente da } \\
\text { organização. }\end{array}$ & $\begin{array}{l}\text { Parcerias com } \\
\text { empresas com o } \\
\text { objetivo de oferecer } \\
\text { maior remuneração } \\
\text { aos jovens surdos, em } \\
\text { troca, promove } \\
\text { programa de inclusão } \\
\text { de deficientes em } \\
\text { empresas. }\end{array}$ & $\begin{array}{l}\text { Ainda não há } \\
\text { contratação. Os } \\
\text { jovens surdos serão } \\
\text { registrados, } \\
\text { recebendo } \\
\text { devidamente os } \\
\text { encargos sociais. }\end{array}$ \\
\hline $\begin{array}{l}\text { Desenvolvimento } \\
\text { de Tecnologia }\end{array}$ & \multicolumn{3}{|c|}{$\begin{array}{l}\text { Global via fundador, uma vez desenvolvida é repassada para todas } \\
\text { unidades. }\end{array}$} \\
\hline $\begin{array}{l}\text { Logística interna, } \\
\text { Operações e } \\
\text { Logística externa }\end{array}$ & $\begin{array}{l}\text { Implementação de } \\
\text { ISO }\end{array}$ & $\begin{array}{l}\text { Implementação de } \\
\text { padronização local } \\
\text { baseada em diretrizes } \\
\text { da ANVISA }\end{array}$ & $\begin{array}{l}\text { Não há produção no } \\
\text { momento. }\end{array}$ \\
\hline $\begin{array}{l}\text { Marketing e } \\
\text { Vendas }\end{array}$ & $\begin{array}{l}\text { Agente de vendas } \\
\text { local }\end{array}$ & $\begin{array}{l}\text { Parceria com } \\
\text { distribuidores locais, } \\
\text { possível parceria com } \\
\text { distribuidor exclusivo }\end{array}$ & $\begin{array}{l}\text { Não há venda no } \\
\text { momento. Possível } \\
\text { parceria com } \\
\text { distribuidores } \\
\text { regionais. }\end{array}$ \\
\hline Serviços & \multicolumn{2}{|c|}{$\begin{array}{l}\text { Assistência Técnica, } 3 \% \text { de doação de } \\
\text { mercadoria em compras acima de } 100 \\
\text { unidades com objetivo de substituir possíveis } \\
\text { defeitos }\end{array}$} & $\begin{array}{l}\text { Não há venda no } \\
\text { momento. }\end{array}$ \\
\hline $\begin{array}{l}\text { Organizações de } \\
\text { Suporte }\end{array}$ & Parceiros locais & $\begin{array}{l}\text { Parceiros locais e } \\
\text { distribuidores }\end{array}$ & Parceiros locais \\
\hline
\end{tabular}

\section{Estrutura organizacional em cada país}

A estrutura organizacional dos trabalhadores do Solar Ear é basicamente a mesma para todas as unidades. Existem os trabalhadores que atuam na produção dos aparelhos; uma pessoa tática que é responsável por controlar a qualidade dos produtos; o professor de comunicação que conheça a cultura dos surdos, responsável pelo desenvolvimento pessoal dos jovens surdos; um gestor da unidade que é normalmente um profissional de 
administração de empresas ou de organizações sociais; um fonoaudiólogo (audiologista); a força de venda.

Algumas funções como consultores externos podem fazer parte do quadro de colaboradores, como por exemplo, advogados, contadores e agências de publicidade. Voluntários também aparecem no quadro de colaboradores como engenheiros, responsável por mídia social, desenvolvimento da linguagem da marca, etc.

As três unidades, Botsuana, Brasil e Jordânia, possuem organogramas internos que se diferenciam na estrutura hierárquica, mas possuem o mesmo perfil de colaboradores. Todas as três têm em sua estrutura interna os seguintes cargos: diretoria/gestão, produção, comitê de qualidade. Todas contam com uma estrutura externa de consultores ou assessores, principalmente para as funções jurídicas e contábeis.

A estrutura no Oriente Médio é a mais complexa e a que mais foge ao modelo de negócio da iniciativa. Apesar de ainda não ter sido implementada, a estrutura contempla três diferentes unidades, cada uma com um gestor diferente e todas coordenadas por um gerente no topo da hierarquia. Das três unidades, duas são destinadas para produção dos equipamentos e a terceira, funcionaria como uma espécie de clínica de atendimento. Cada unidade se localiza em diferentes países (Jordânia, Palestina e Israel).

Apesar da estrutura aparecer neste formato, atualmente, a iniciativa apenas conta com uma unidade na Jordânia, porém já possui o gerente geral e o gerente local. A justificativa para essa estrutura seria as dificuldades com relação à questão política que proíbe, por exemplo, Palestinos cruzarem a fronteira de Israel, ou ainda, questões econômicas como o embargo que os países árabes fazem a produtos vindos de Israel. Essa forma alternativa de se estruturar ainda está sendo testada e não se pode dizer ao certo se irá se consolidar ao longo dos anos.

Com relação às competências da população envolvida com a iniciativa, a principal caracterírstica que as diferencia no mercado de trabalho é a capacidade motora, pois ao se comunicar com as mãos, em língua de sinais, os surdos em geral desenvolvem uma habilidade motora superior à dos ouvintes. Essa habilidade é ideal para o trabalho preciso 
da micro-soldagem eletrônica desenvolvido pela Solar Ear.

Segundo a visão do fundador, dentre seus principais desafios está aceitar as diferenças de cada gestor e trabalhar com as personalidades de cada um.

A iniciativa garante que as competências sejam desenvolvidas internamente, pois segundo o fundador, as pessoas sempre estão sendo desafiadas, elas recebem a oportunidade de crescer e se superar a cada dia.

Os colaboradores e funcionários são os seus principais stakeholders, bem como a comunidade de surdos. Cada unidade está aberta para novas idéias vindas desta comunidade, porém é mantido o foco na atividade para que se garanta sempre sua visão e missão. Ainda com relação à população surda empregada, o maior desafio é criar neles o sentimento de pertencimento e responsabilidade. Muitas vezes o deficiente auditivo tem uma grande falta de confiança própria por serem tratados como vítimas. Assim, cada unidade procura desenvolver ao máximo a participação da população em decisões.

De acordo com o fundador, o valor econômico gerado é reinvestido na organização, em novos treinamentos de pessoas surdas ou na missão social que cada organização queira desenvolver, mas sempre ligada às pessoas da organização. No caso de Botsuana, esse retorno é investido no trabalho de redução do índice de HIV entre as pessoas surdas. No Brasil, vai para financiar desenvolvimento fonoaudiológico em pessoas de baixa renda (esse serviço é prestado pela matriz do Instituto CEFAC). No caso do Oriente Médio, esse recurso será investido na propagação da paz, por diversas atividades de colaboração entre israelenses, palestinos e jordanianos.

\section{$\underline{\text { Porte de cada unidade Solar Ear }}$}

Um dos pré-requisitos para criação de uma nova unidade do Solar Ear é o recebimento de uma doação entre 300 mil a 400 mil dólares. Segundo o seu modelo de negócio, esse recurso deve vir $80 \%$ de uma organização financiadora e $20 \%$ deve ser levantado localmente pela organização parceira local, como forma de comprometimento com a iniciativa. 
A seguir será apresentado uma tabela que resume e compara as receitas e despesas das três unidades nos primeiros dois anos de implementação (ano 0 e ano 1). Essa tabela mostra investimento inicial (doações recebidas) em cada unidade, os tipos de gastos iniciais e sua distribuição ao longo do tempo, bem como o retorno desses investimentos, a partir do ano 1. No caso da Jordânia, os dados do ano 1 incluem uma projeção das despesas de agosto de 2011 a julho de 2012.

Tabela 1 - Comparativo Receitas e Despesas nos três países

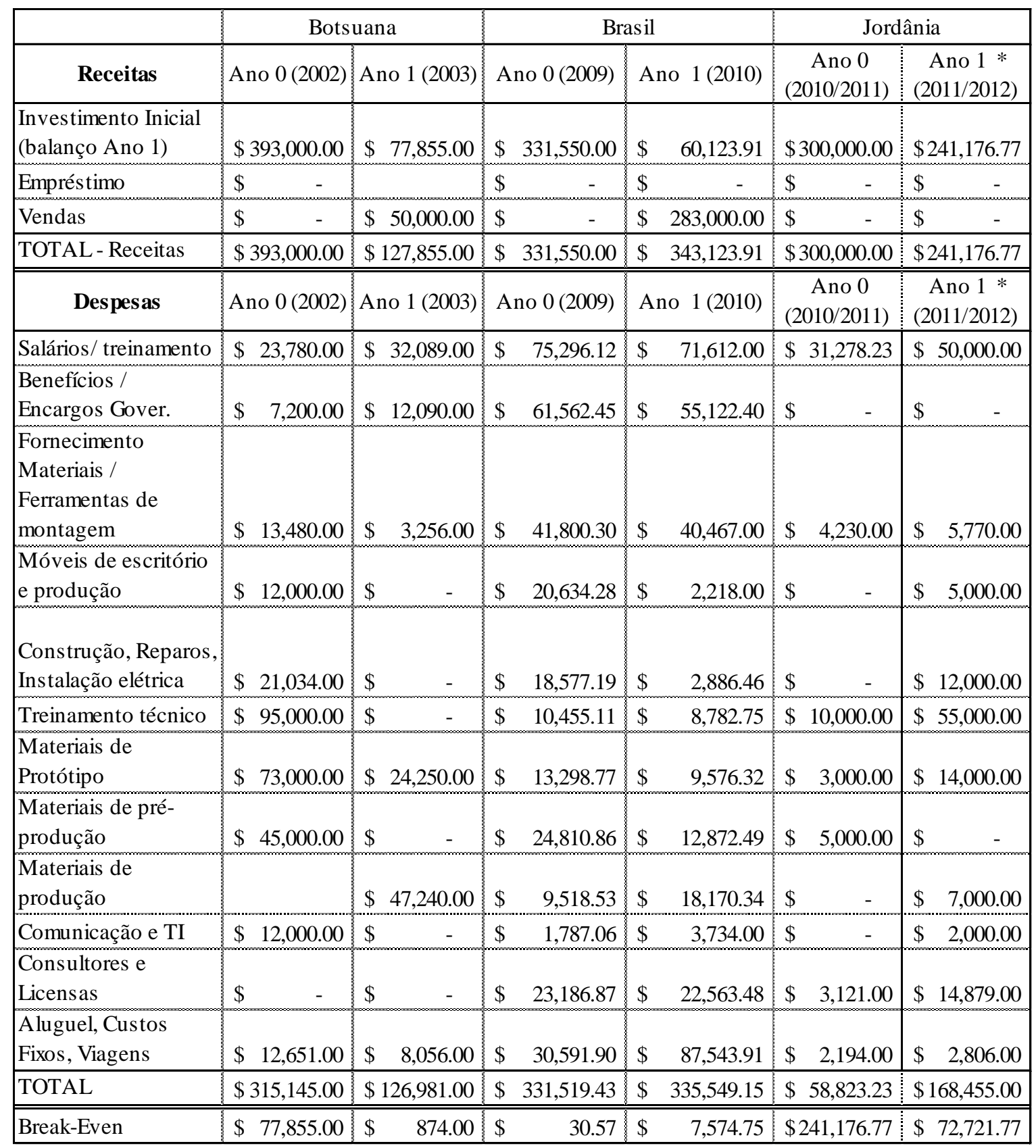

*ano 1 - Jordânia é relativo a projeções. 
Pode-se observar a partir do ano 1 que Botsuana e Brasil já possuem retorno do investimento em vendas. $\mathrm{O}$ valor recebido em Botsuana é equivalente à venda de aproximadamente 340 unidades de um "kit" do Solar Ear, que inclui: um carregador solar, duas baterias recarregáveis e um aparelho auditivo. No caso brasileiro, no ano 1 foram vendidas aproximadamente 2000 unidades, essencialmente para o exterior devido à necessidade de certificações que ainda não foram obtidas com relação à venda do produto no mercado brasileiro.

Algumas despesas como "protótipo de materiais" têm valor maior em Botsuana, pois as outras unidades se beneficiam do mesmo desenvolvimento de produtos. $\mathrm{O}$ mesmo acontece para o "treinamento", visto que o primeiro grupo de trabalhadores surdos de Botsuana participou de um curso de micro-solda de aviação de duração de 18 semanas no Canadá.

No caso da Jordânia, a unidade está em sua fase inicial, com o desenvolvimento do treinamento técnico, portanto ainda não comercializa nenhum produto. Mas a partir dos dados financeiros, já é possível ter evidências de rentabilidade e sustentabilidade financeira do modelo. No caso brasileiro, foi possível observar retorno positivo a partir do $18^{\circ}$ mês do início das atividades. Porém, há despesas muito mais elevadas como no caso de viagens e estadias. O motivo desse dispêndio maior está ligado ao fato de que o fundador, se encontra instalado na unidade brasileira. Isso representa dizer que custos que seriam de uma possível matriz são incorridos no orçamento da unidade e não são repassados para as outras unidades, como é o caso da participação em congressos para divulgação, viagens para formalização de novas parcerias ou viagens para criação de novas unidades.

Interessante notar que no investimento inicial já está inclusa a compra de matéria prima para a produção das primeiras 2000 unidades de produto e com a margem de ganho da venda destas unidades é possível atingir a sustentabilidade financeira (break-even).

\section{Valor Financeiro e Social}

Analisando cada uma das unidades sob o ponto de vista da sustentabilidade financeira e 
rentabilidade, pode-se observar a partir de relatórios disponibilizados, que a sustentabilidade financeira está na venda anual de 2000 a 3000 unidades de um "kit" de produtos que inclui um carregador solar, duas baterias recarregáveis de aparelho auditivo e um aparelho auditivo.

Em Botsuana, no segundo ano de atividades, já há a comercialização dos produtos, porém foi preciso um esforço inicial para que os clientes potenciais conhecessem o produto.

A unidade no Brasil já se beneficiou da divulgação do produto iniciada por Botsuana. Analisando os 2 primeiros anos da implementação da unidade brasileira, já se pode observar evidências de auto-sustentabilidade, porém ainda não há praticamente excedente, isto é, ainda não há rentabilidade. Aprofundando um pouco mais a análise é possível afirmar que isso se dá especialmente no caso brasileiro, pois a unidade assume despesas como viagens e estadias para firmar parcerias de criação de novas unidades ou para desenvolver parceiros que irão beneficiar todas as unidades.

No caso da Jordânia, ainda não há a comercialização dos produtos, porém a gestora acredita que é possível atingir a sustentabilidade financeira já a partir do $2^{\circ}$ ano, isso devido a grande visibilidade que o produto já possui, além de parcerias estratégicas feitas pelo fundador.

Devido a variedade e diferenças nos custos dos aparelhos auditivos, criou-se um preço médio por "kit" baseado nos mesmos produtos citados anteriormente. Todos os valores estão na unidade monetária do dólar para facilitar a comparação entre todas as unidades. Assim sendo, um "kit" em média custaria 150 dólares com retorno sobre vendas de $50 \%$.

De acordo com dados do projeto, o valor econômico gerado é reinvestido na organização, em novos treinamentos de pessoas surdas ou na missão social que cada organização queira desenvolver. No caso de Botsuana, esse retorno é investido no trabalho de redução do índice de HIV entre as pessoas surdas. No Brasil, vai para financiar desenvolvimento fonoaudiológico em pessoas de baixa renda (esse serviço é prestado pela matriz do Instituto CEFAC). No caso da Jordânia, esse recurso será investido na propagação da paz, por diversas atividades de colaboração entre israelenses, palestinos e jordanianos. 
Atualmente, não se pode observar nenhuma forma de mensuração efetiva do valor social criado pela iniciativa, pois nenhuma das três unidades está desenvolvendo relatórios sociais, além dos relatórios de governança solicitados pelas organizações financiadoras. Porém ao se entrevistar a população envolvida, evidencia-se uma forte melhoria nas condições de vida, não só do indivíduo diretamente ligado à iniciativa, como também da família. Essa melhoria está ligada principalmente a três fatores: melhoria do nível de renda familiar, desenvolvimento pessoal e desenvolvimento profissional. Um exemplo disso foi o fato de dois trabalhadores que iniciaram cursos superiores em 2010 e outros dois buscaram cursos de inglês após a convivência com os professores surdos vindos de Botsuana. 


\section{CONSIDERAÇÕES FINAIS}

Diferentes nomes têm sido utilizados para definir um fenômeno cada vez mais comum: a existência de organizações que visam solucionar problemas sociais a partir de mecanismos de mercado. A utilização de conceitos como empresas sociais (social enterprise), negócios inclusivos (inclusive business) e negócios sociais (social business) para definir uma iniciativa social tem suscitado intensos debates, tanto entre acadêmicos como entre empreendedores.

Para além da terminologia, a grande novidade é que o diálogo entre as organizações sociais e a iniciativa privada, não só é cada dia mais comum, como também se tornou necessário para alcançar e ampliar o impacto social desejado. Dois objetivos antes vistos como incompatíveis - sustentabilidade financeira e geração de valor social - tornaram-se indissociáveis e são o eixo fundamental do funcionamento dessas organizações.

Apesar da ambigüidade e diversidade dos termos, pode-se afirmar que este tipo de empreendimento social exige um novo formato. Novas também são as exigências feitas aos gestores deste tipo empreendimentos que desde a sua criação devem gerenciar eventuais conflitos e tensões que ocorrem na medida em que é necessário maximizar retorno social com rentabilidade financeira. Para isso, é necessário quebrar paradigmas presentes na forma tradicional de fazer negócios e de atuar no social.

Desde o momento zero do empreendimento, é fundamental inovar e viabilizar novos arranjos institucionais. Não é possível reproduzir o modelo tradicional de se fazer negócio, inserindo apenas a dimensão social. É necessário que organizações da sociedade civil juntem esforços com organizações empresariais e ambos pensem de que forma podem colarborar, sob a lei de mercado, com o objetivo comum de contribuir para reverter a situação de exclusão.

A idéia de Negócios Inclusivos vai além da combinação sustentabilidade financeira e geração de valor social, pois prevê a efetiva inserção de pobres e minorias no negócio social. Cabe destacar que a produtividade, a capacidade inventiva e a qualificação não formal, ou melhor, a sua capacidade de dar respostas adequadas às demandas cotidianas 
no trabalho, pode ser bastante expressiva por parte dos trabalhadores envolvidos em Negócios Inclusivos. Não se trata, portanto, de filantropia, mas sim de transações mercantis fundadas em rentabilidade e desempenho econômico.

No entanto, existem riscos ligados à inserção dessa mão-de-obra nos negócios inclusivos, mesmo adotando-se uma agenda de respeito à legislação trabalhista. $\mathrm{O}$ fato de terem poucas oportunidades de emprego e baixa mobilidade o mercado de trabalho não pode servir de pretexto para que se pratiquem baixos salários ou mesmo se opte por esse tipo de trabalhador esperando deles maior subserviência. Assim sendo, ao se falar em negócios inclusivos, deve-se garantir que o envolvimento da população aconteça por meio de participação efetiva.

Além disso, segundo Teodósio (2011), é importante saber que o mercado é um instrumento necessário, mas não suficiente para solucionar os problemas sociais e ainda, que a expansão do consumo de produtos e serviços com baixa eficiência ecológica em negócios inclusivos podem aumentar o nível de degradação ambiental.

O caso analisado neste trabalho demonstra ser um caso de negócio inclusivo pela característica de forte comprometimento com seu ecossistema. Além do ambiente participativo e da valorização dos indivíduos com programas específicos para o desenvolvimento pessoal e profissional, a organização estudada apresenta outras características que podem ser consideradas como essenciais em negócios sociais, como: (i) a relação estratégica com stakeholders; (ii) a redução dos custos de transação, atuando em colaboração com outras organizações, por exemplo, parceria com distribuidores; (iii) a utilização de infra-estrutura social já existente, ao inserir novas unidades em organizações que já atuam no setor, beneficiando-se da rica carteira de relações e de confiança construída ao longo dos anos com os setores de baixa renda, como um ativo produtivo que permite gerar recursos econômicos enquanto se persegue a missão social; (iv) a replicação do modelo em novas iniciativas para ganhar em "economia de escala", assim, na medida em que a produção aumenta, o custo por unidade tende a cair e, por fim, ainda que não concretizado, mas presente no discurso da iniciativa, (v) projetos de lançar outros produtos e de desenvolver atividades complementares, gerando "economia de escopo". 
As características anteriormente levantadas estão relacionadas com os aspectos levantados por Reficco e Vernis (2010) e correlacionados no quadro a seguir.

\section{Quadro 12 - Comprometimento com o ecossistema}

\begin{tabular}{l|l|}
\hline Reficco e Vernis (2010) & Solar Ear \\
\hline $\begin{array}{l}\text { Relações com stakeholders: o nível de interação com } \\
\text { stakeholders (internos e externos) }\end{array}$ & $\begin{array}{l}\text { Fornecedores são parceiros do negócio } \\
\text { Inclusão da população surda, ambiente } \\
\text { participativo, programa de desenvolvimento }\end{array}$ \\
\hline $\begin{array}{l}\text { Redução das incertezas possibilitando a entrada de } \\
\text { investimentos: engajar membros do ecossistema } \\
\text { com a construção de ligações efetivas entre a oferta } \\
\text { e a demanda }\end{array}$ & $\begin{array}{l}\text { Fornecedores atendem a modificações do produto, } \\
\text { conforme necessidade, sem repassar custos }\end{array}$ \\
\hline $\begin{array}{l}\text { Redução dos custos de transação: observar como a } \\
\text { organização consegue aumentar sua margem de } \\
\text { ganho, garantindo o acesso dos produtos e serviços } \\
\text { à população de baixa renda. }\end{array}$ & $\begin{array}{l}\text { Redução dos custos de transação (parcerias com } \\
\text { outras organizações, ex: fornecedores que } \\
\text { entendem a missão social e distribuição). }\end{array}$ \\
\hline $\begin{array}{l}\text { Utilizar a infra-estrutura social já existente: deve-se } \\
\text { levar em conta na análise, o ganho de escala e de } \\
\text { escopo pelas iniciativas de negócios inclusivos. }\end{array}$ & $\begin{array}{l}\text { Utilização da infra-estrutura já existente, novas } \\
\text { unidades são implementada em organizações que já } \\
\text { atuam no setor }\end{array}$ \\
\hline $\begin{array}{l}\text { Replicação do modelo e ganho de escala (aumento } \\
\text { da produção, redução de custo unitario) }\end{array}$ \\
\hline \begin{tabular}{l} 
Potencial economia de escopo \\
\hline
\end{tabular}
\end{tabular}

No caso específico da iniciativa estudada, deve ser levado em conta com atenção o seguinte aspecto, visto como crítico para sua perpetuação: vê-se necessário o desenvolvimento de padronização para a replicabilidade do modelo (processos), um sistema de governança (relatórios, accountability e auditorias), definições específicas do papel de cada unidade, seus direitos e deveres, bem como métodos de mensuração e avaliação do impacto social e econômico.

Esses aspectos podem surgir por meio de uma estrutura matricial ainda não existente ou serem mantidos sob a responsabilidade do fundador, porém, recomenda-se a $\mathrm{o}$ investimento em aspectos ligados à gestão de pessoas, principalmente relacionados a um plano sucessório.

Chama a atenção, a falta de um sistema de governança onde estariam inclusas a prestação de contas, a criação de um conselho e auditorias. Como observado anteriormente, o sistema de governança do Solar Ear está relacionado com a missão e os requerimentos dos financiadores, que possuem protocolos específicos que devem ser seguidos. As exigências dos financiadores permite que a organização crie relatórios periódicos, porém, 
não há nenhum sistema que garanta a accountability e transparência. É importante ressaltar o fato de que nenhuma das três unidades possui relatórios divulgados em seu site.

Dentre as três unidades, a Jordânia parece ser a que mais se distancia do modelo de negócio da iniciativa. Isto acontece, pois os critérios definidos para as organizações parceiras não foram cumpridos na Jordânia e pelo gerente ter criado uma estrutura com três unidades em uma mesma região, criando concorrentes no mesmo mercado e triplicando os custos operacionais.

Além disso, os recursos recebidos para financiar a iniciativa são investidos de acordo com os interesses da organização parceira local (RSS) sem qualquer controle do fundador, devendo prestar contas apenas para a organização financiadora, sem nenhuma obrigação para com o fundador.

Assim, a inexistência de um controle por parte do fundador, pode gerar problemas em diversos âmbitos como uso correto dos recursos, qualidade final dos produtos, garantia do cumprimento da missão social, etc.

Pode-se levantar como hipótese que este fator só apareceu na Jordânia, pois o fundador não esteve presente durante sua implementação como foi o caso de Botsuana e Brasil, assim no caso da Jordânia, a distância e a grande autonomia dada na implementação da iniciativa pode ter dificultado o processo de implementação.

Dessa forma, acredita-se que a presença do fundador no local durante a implementação é fundamental para geração de proximidade e confiança mútua. No caso de Botsuana e Brasil, a relação entre fundador e gestor local não apresentou problemas, visto que o fundador esteve presente na fase inicial.

Ao analisar as três iniciativas, percebe-se que a falta de uma estrutura formal hierárquica pode ter um impacto negativo na sua efetiva implementação, uma vez que o gerente de cada uma responde ao mesmo tempo para os interesses da organização local onde foi implementada a iniciativa e para o fundador. Como recomendação, o estreitamento entre 
fundador e gerente poderia ser feito via criação de uma estrutura formal, estabelecimento de direitos e deveres e ainda, com o possível vínculo salarial e empregatício abaixo do fundador. Na visão do fundador, a criação da estrutura do tipo franchising deverá fazer parte da estrutura organizacional da iniciativa, o que pode minimizar os problemas acima descritos.

O fundador é, portanto, o grande vínculo entre as unidades; sua principal função consiste em dar apoio à continuidade de todas iniciativas, bem como a criação de novas. Dessa forma, sua ausência na iniciativa poderia gerar uma grande dificuldade na perpetuação de todas as unidades, pois nenhum processo sucessório foi iniciado.

Com relação ao mercado, é importante superar os desafios da distribuição dos produtos que necessita de profissionais especializados e equipamentos sofisiticados. Deve-se também fazer um esforço para redução dos preços dos produtos, para poder também atingir as camadas mais pobres (classe D e E). Além disso, tem se como hipótese que o fato das empresas concorrentes investirem altos valores em divulgação, bem como benefícios para os fonoaudiólogos oferecerem seus produtos aos clientes, dificulta a participação da iniciativa no mercado, principalmente entre a classe média (classe B e C).

$\underline{\text { Impacto social, ambiental ou econômico }}$

De acordo com o fundador, o impacto social na sociedade está ligado à mudança de concepção quanto ao potencial profissional dos deficientes auditivos. Isso acontece ao colocar no mercado um produto de qualidade, manufaturado por pessoas surdas, para as quais os impactos sociais e econômicos são a oportunidade de profissionalização e crescimento profissional e empregabilidade, com o conseqüente aumento de renda familiar. Para os deficientes auditivos o impacto é o acesso a produtos mais baratos e essenciais para sua inclusão na sociedade, além da economia com as baterias recarregáveis. A inclusão dos indivíduos na sociedade acontece, principalmente, quando a perda auditiva é identificada bem cedo na infância. Com a adaptação de um aparelho auditivo em uma criança, é possível observar uma melhora significativa da fala entre outros fatores essenciais para seu desenvolvimento o que também reduz futuros custos com recursos educacionais especiais (HEAR IT, 2011). Assim, segundo o fundador do projeto, existem estudos que mostram que ajudar pessoas com deficiência pode aumentar 
o PIB do país de 3 a $4 \%$.

O impacto ambiental é também um aspecto importante, visto que uma bateria recarregável, segundo os estudos da iniciativa, tem duração de dois a três anos, enquanto que as baterias descartáveis, uma semana. Atualmente 200 milhões de baterias são descartadas anualmente. Assim, a proposta da iniciativa pode apresentar um alto impacto na redução das baterias descartadas atualmente no meio ambiente.

Em resumo, a iniciativa parece combinar alto valor social e financeiro devido ao grande mercado não atendido. Porém, atualmente, não se pode observar nenhuma forma de mensuração efetiva do valor social criado pela iniciativa, pois nenhuma das três iniciativas está desenvolvendo relatórios sociais, além dos relatórios de governança solicitados pelas organizações financiadoras. Ao se entrevistar a população envolvida, evidencia-se uma forte melhoria nas condições de vida, não só do indivíduo diretamente ligado à iniciativa, como também da família. Essa melhoria está ligada principalmente a três fatores: melhoria do nível de renda familiar, desenvolvimento pessoal e desenvolvimento profissional. Um exemplo disso foi o fato de dois trabalhadores que iniciaram cursos superiores em 2010 e outros dois buscaram cursos de inglês após a convivência com os professores surdos vindos de Botsuana.

Reforça-se, ainda, que o distanciamento do controle do fundador, a falta de relatórios e accountability que garantam a transparência de cada uma das unidades ou ainda, a falta de contratos formais que estabeleçam direitos e deveres de cada stakeholder, possam ser complicadores na replicação do modelo.

Como recomendações para a organização, sugere-se: (i) a padronização dos processos operacionais e a definição de estratégias mais sólidas para facilitar a replicabilidade da iniciativa; (ii) criação de um sistema de governança com divulgação de relatórios e auditorias, não só para financiadores, mas para todos stakeholders a fim de garantir a participação efetiva da população envolvida e obter mais credibilidade; (iii) definições das funções, direitos e deveres de cada unidade em cada país e criação de uma estrutura matricial; (iv) criação de um plano de sucessão para as atividades do fundador e dos gerentes; (v) por um espaço curto de tempo (até o momento onde houver a estrutura 
matricial), aproximação do fundador com os gerentes de cada unidade; (vi) definição de métodos de mensuração e avaliação de impacto social e econômico; (vii) desenvolvimento de novos produtos é essencial para atingir novos mercados (exempo D e E) - mix de produtos; (viii) Desenvolver um mix de formas de produção com o intuito de atender toda a demanda em momentos de crise.

O trabalho apresentou algumas limitações como: dificuldade de acesso aos dados, principalmente informações financeiras (especialmente Botsuana e Jordânia) e indicadores sociais que não são medidos em nenhuma das unidades; dificuldade de comparação entre diferentes moedas em momentos diferentes, nem sempre representando o valor atual da moeda local, devido à inflação e correções monetárias; dados financeiros não constavam em relatórios padronizados, isto é, foram utilizados diferentes parâmetros e alguns não eram contabilizados; parte das entrevistas não foram suficiente para inferir análise sobre questões do questionário/protocolo; a entrevista com fundador teve muito mais peso do que as outras entrevistas, acredita-se que pela visão global e estratégica da organização e facilidade de acesso ao entrevistado; não foi possível entrevistar cliente (ONG humanitária).

Como oportunidades para futuras pesquisas, pode ser interessante analisar alguns aspectos como: discutir negócios inclusivos levando em conta atores como o Estado e a Sociedade Civil; observar nos próximos anos a sustentabilidade financeira de cada unidade do Solar Ear; verificar se os FCS levantados podem aumentar o desempenho organizacional no momento em que houver a consolidação da iniciativa, segundo teoria de Drucker (1973); discussão teórica sobre o tempo de amadurecimento de um negócio inclusivo, que parece ser mais longo do que um negócio tradicional; manter, em estudos qualitativos, a teoria de ecossistema, pois mostrou-se muito relevante ao se tratar de Negócios Inclusivos; focar, por exemplo, pontos do ecossistema, como análise estratégica em Marketing - pontos de vendas, diversificação dos produtos, inovação e novos mercados, etc.; desenvolver pesquisas sobre os negócios inclusivos em um setor específico da economia; desenvolver pesquisas quantitativas.

\section{REFERÊNCIAS BIBLIOGRÁFICAS}


AMIN, Ash. Extraordinarily ordinary: working in the social economy. Social Enterprise Journal. 2009. Disponível em: http://www.emeraldinsight.com/10.1108/17508610910956390. Acesso em: Out/2010.

AUSTIN, James E. The collaboration challenge: how nonprofits and businesses succeed through strategic alliances. 1st ed. The Drucker Foundation Future Series. San Francisco, Calif.: Jossey-Bass, 2000.

BANCO MUNDIAL, Poverty Reduction \& Equity: the developing world is poorer than we thought, but no less successful in the fight against povert, 2008. Disponível em: <http://wwWwds.worldbank.org/external/default/WDSContentServer/WDSP/IB/2010/01/21/00015834 9_20100121133109/Rendered/PDF/WPS4703.pdf>. Acesso em 16/01/2011.

BASHEER, Al-alak. Islamic Entrepreneurship: an ongoing driver for social change. Interdisciplinary Journal of Contemporary Research In Business.Vol. 1, Nbr. 12, April 2010.

BASTOS, Elide Rugai et al (Org). Conversa com sociólogos brasileiros. São Paulo: Editora 34, 2006.

BERKES, F.; DAVIDSON-HUNT, I. J. Communities and social enterprises in the age of globalization. Journal of Enterprising Communities: People and Places in the Global Economy. $2007 . \quad$ Disponível em: http://www.emeraldinsight.com/10.1108/17506200710779521. Acesso em: Out/2010.

BOIK, J. Social business and e-democracy in America: two proposals. A book in progress. Disponível em: www.siteforchange.com Acesso em: Jan/2011.

BORZA, A.; NISTOR, R.; BORDEAN, O.; MITRA, C. The social impact of nongovernmental organizations. Revista de Management si Inginerie Economica. v.8 nr 2:53-67. Romania. 2009.

BORZAGA, Carlo; GALERA, Giulia. Social enterprise: an international overview of its conceptual evolution and legal implementation. Social Enterprise Journal, v.5 Iss: 3, p. $210-228,2009$.

BOYNTON, A. C.; ZMUND, R.W. An Assessment of Critical Success Factors. Sloan Management Review, 24,4. 3. 1984.

BROWN, J. Equity finance for social enterprises. Social Enterprise Journal. v.2 (1):7381. 2006. Disponível em: http://www.emeraldinsight.com/10.1108/17508610680000714. Acesso em: Out/2010.

BULL, M. "Balance": the development of a social enterprise business performance analysis tool. Social Enterprise Journal.v.3(1):49-66. 2007. Disponível em: http://www.emeraldinsight.com/journals.htm?articleid=1728442\&amp;show=abstract.

Acesso em: Out/2010.

BULL, M. Challenging tensions: critical, theoretical and empirical perspectives on social enterprise. International Journal of Entrepreneurial Behaviour \& Research. v.14(5):268- 
275.

2008.

Disponível

em:

http://www.emeraldinsight.com/10.1108/13552550810897641. Acesso em: Out/2010.

BULL, M.; CROMPTON, H. Business practices in social enterprises. Social Enterprise Journal.v.2(1):42-60. $2006 . \quad$ Disponível em: http://www.emeraldinsight.com/10.1108/17508610680000712. Acesso em: Out/2010.

BULL, M.; CROMPTON, H.; JAYAWARNA, D. Coming from the heart (the road is long). Social Enterprise Journal. v.4(2):108-125. 2008. Disponível em: http://www.emeraldinsight.com/10.1108/17508610810902002. Acesso em: Out/2010.

CATO, M.S.; ARTHUR L.; SMITH, R.; KEENOY, T. So you like to play the guitar? Music-based social enterprise as a response to economic inactivity. Social Enterprise Journal. $\quad$ v.3(1):101-112. 2007.2 Disponível em: http://www.emeraldinsight.com/10.1108/17508610780000725. Acesso em: Out/2010.

CHAPMAN, T.; FORBES, D.; BROWN, J. They have God on their side: the impact of public sector attitudes on the development of social enterprise. Social Enterprise Journal. v.3(1):78-89. $2007 . \quad$ Disponível em: http://www.emeraldinsight.com/10.1108/17508610780000723. Acesso em: Out/2010.

CHAWLA, H. Amul. India: A Social Development Enterprise. Asian Case Research Journal. v.11(02):293. 2007.2 Disponível em: http://www.worldscinet.com/acrj/11/1102/S0218927507000941.html. Acesso em: Out $/ 2010$.

CHELL, E. Social Enterprise and Entrepreneurship: towards a convergent theory of the entrepreneurial process. International Small Business Journal.v.25(1):5-26. 2007. Disponível em: http://isb.sagepub.com/cgi/doi/10.1177/0266242607071779. Acesso em: Out/2010.

CONWAY, C. Business planning training for social enterprise. Social Enterprise Journal.v.4(1):57-73. 2008.2 Disponível em: http://www.emeraldinsight.com/10.1108/17508610810877731. Acesso em: Out/2010.

COONEY, K. The Institutional and Technical Structuring of Nonprofit Ventures: case study of a U.S. hybrid organization caught between two fields. Voluntas: International Journal of Voluntary and Nonprofit Organizations.v.17(2):137-155. 2006. Disponível em: http://www.springerlink.com/index/10.1007/s11266-006-9010-8. Acesso em: Out/2010.

CORNELIUS, N. et al. Corporate social responsibility and the social enterprise. Journal of business ethics.v.81(2):355-370. 2008. Disponível em: http://www.springerlink.com/index/hp1hkw4m286471u1.pdf. Acesso em: Out/2010.

COSTA, R.S. Processo de compra corporativa de software: um estudo exploratório dos atributos que influenciam na decisão. Dissertação (Mestrado em Administração) Programa de Pós-Graduação em Administração, Escola de Administração, Universidade Federal do Rio Grande do Sul, Porto Alegre, 2007.

CULL, R. Microfinance Meets the Market. Journal of Economic Perspectives. v.71(3):393-192. 2009. 
CURRY, J. DONKER, H., KREHBIEL, R. Development Corporations in Aboriginal Communities: the canadian experience. Journal of Developmental Entrepreneurship. v.14(1):1-19. 2009.

CURTIS, T. Finding that grit makes a pearl: A critical re-reading of research into social enterprise. International Journal of Entrepreneurial Behaviour \& Research.v.14(5):276-290. 2008. Disponível em: http://www.emeraldinsight.com/10.1108/13552550810897650. Acesso em: Out/2010.

DARBY, L.; JENKINS, H. Applying sustainability indicators to the social enterprise business model: the development and application of an indicator set for Newport Wastesavers, Wales. International Journal of Social Economics. v.33(5/6):411-431. 2006. Disponível em: http://www.emeraldinsight.com/10.1108/03068290610660689. Acesso em: Out/2010.

DEES, J. Gregory. O Significado do "Empreendorismo Social”. Versão original: 31 de Outubro de 1998. Versão revista e reformulada: 30 de Maio de 2001. Center for the Advancement of Social Entrepreneurship. 1998.

DEFOURNY J; NYSSENS, M. Social enterprise in Europe: recent trends and developments. Social Enterprise Journal. v.4(3):202-228. 2008. Disponível em: http://www.emeraldinsight.com/10.1108/17508610810922703. Acesso em: Out/2010.

DI DOMENICO, M. L. The dialectic of social exchange: theorising corporate-social enterprise collaboration. Organization Studies. 2009. Disponível em: http://oss.sagepub.com/cgi/doi/10.1177/0170840609334954. Acesso em: Out/2010.

DIOCHON, M.; ANDERSON, A. R. Social enterprise and effectiveness: a process typology. Social Enterprise Journal. v.5(1):7-29. 2009. Disponível em: http://www.emeraldinsight.com/10.1108/17508610910956381. Acesso em: Out/2010.

DIXON, S. E.; CLIFFORD, A. Ecopreneurship: a new approach to managing the triple bottom line. Journal of Organizational Change Management. v.20(3):326-345. 2007. Disponível em: http://www.emeraldinsight.com/10.1108/09534810710740164. Acesso em: Out/2010.

DRUCKER, P. F. Management: Tasks, Responsibilities and Practices. 1973.Transaction Publishers.

EDERY, Y. Ethical developments in finance: implications for charities and social enterprise. Social Enterprise Journal.v.2(1):82-100. 2006. Disponível em: http://scholar.google.com/scholar?hl=en\&btnG=Search\&q=intitle:Ethical+developments+ in+finance+:+Implications+for+charities+and+social+enterprise\#0. Acesso em: Out/2010.

EMES. European Research Network. Disponível em http://www.emes.net/index.php?id=203. Acesso em 15 de jun. 2010.

FISCHER, Rosa Maria; FEDATO, Cristina; SOUZA NOVAES, Maria Elidia. A responsabilidade pelo desenvolvimento. Conferência Internacional ISTR. 23. 2004. 
GALERA, G.; BORZAGA, C. Social enterprise: an international overview of its conceptual evolution and legal implementation. Social Enterprise Journal.v.5(3):210-228. 2009. Disponível em: http://www.emeraldinsight.com/10.1108/17508610911004313. Acesso em: Out/2010.

GHALIB, A.; HOSSAIN, F.; ARUN, T. Social Responsibility, Business Strategy and Development: The Case of Grameen-Danone Foods Limited. Strategy. V.3(4):1-15. 2009.

GIBBON J.; AFFLECK, A. Social enterprise resisting social accounting: reflecting on lived experiences. Social Enterprise Journal.V.4(1):41-56. 2008. Disponível em: http://www.emeraldinsight.com/10.1108/17508610810877722. Acesso em: Out/2010.

GIL, Antônio C. Métodos e Técnicas de Pesquisa Social. São Paulo: Atlas, 1999.

GIRLING R. Global Innovators: How Some Companies Are Working To Improve Social Conditions Around The World. Disponível em: http://www.nabusinesspress.com/JABE/GirlingWeb.pdf. Acesso em: Out/2010.

GODOY, A. S. Introdução à pesquisa qualitativa e suas possibilidades. In: Revista de Administração de Empresas. São Paulo: v.35, n.2, p. 57-63, abril 1995.

GORDON, I. Marketing de Relacionamento: Estratégias, Técnicas e Tecnologias para conquistar Clientes e Mantê-los Sempre. São Paulo: Futura, 2001.

GOVERNO DO REINO UNIDO, Departamento de Comércio e da Indústria. Social Enterprise: a strategy for success. 2001. Disponível em: http://www.seeewiki.co.uk/ wiki/images/5/5a/SE_Strategy_for_success.pdf. Acesso em 18 de janeiro de 2011.

GOVERNO FEDERAL DO BRASIL. Ministério do Planejamento. Disponível em http://pgpe.planejamento.gov.br/os.htm. Acesso em 20 de janeiro de 2011.

GRADL, C.; KRAMER, A. Partner Selection for Inclusive Business Models. 2010.

GRANT, S. Contextualising social enterprise in New Zealand. Social Enterprise Journal. V.4(1):9-23. 2008. Disponível em: http://www.emeraldinsight.com/10.1108/17508610810877704. Acesso em: Out/2010.

GRAZIANO, Luigi. Pluralismo em perspectiva comparativa: notas sobre as tradições européia e americana. Artigo publicado originalmente em Communist and PostCommunist Studies, vol. 26, $\mathrm{n}^{\circ}$ 4, dezembro 1993, 341-51. Disponível em: http://www.anpocs.org.br/portal/publicacoes/rbcs_00_26/rbcs26_01.htm. Acesso em: 07 de fev. 2011.

GUNN, R.; DURKIN, C.; SINGH, G.; BROWN, J. Social entrepreneurship in the social policy curriculum. Social Enterprise Journal.V.4(1):74-80. 2008. Disponível em: http://www.emeraldinsight.com/10.1108/17508610810877740. Acesso em: Out/2010.

GUTHRIE, D.; DURAND, R. Social issues in the study of management. European Management Review. V.5(3):137-149. 2008. Disponível em: http://www.palgravejournals.com/doifinder/10.1057/emr.2008.17. Acesso em: Out/2010. 
HARDING R. Social Enterprise: The new economic engine. Business Strategy Review. 43. 2004.

HARE, P.; JONES, D.; BLACKLEDGE, G. Understanding social enterprise: a case study of the childcare sector in Scotland. Social Enterprise Journal.V.3(1):113-125. 2007. Disponível em: http://www.emeraldinsight.com/10.1108/17508610780000726. Acesso em: Out/2010.

HAUGH, H.; RUBERY, E. Educating Managers to Lead Community Enterprises. International Journal of Public Administration.V.28(9-10):887-902. 2005. Disponível em: http://www.informaworld.com/openurl?genre=article\&doi=10.1081/PAD-

200067384\&magic $=$ crossref $\|$ D404A21C5BB053405B1A640AFFD44AE3. Acesso em: Out/2010.

HEAR IT - http://www.hear-it.org/page.dsp?page=1490, acesso em 09 de junho de 2011.

HO AP, Y.; CHAN K, T. The social impact of work-integration social enterprise in Hong Kong. International Social Work. V.53(1):33-45. 2010. Disponível em: http://isw.sagepub.com/cgi/doi/10.1177/0020872809348950. Acesso em: Out/2010.

HORST, D. V. D. Social enterprise and renewable energy: emerging initiatives and communities of practice. Social Enterprise Journal. V.4(3):171-185. 2008. Disponível em: http://www.emeraldinsight.com/10.1108/17508610810922686. Acesso em: Out/2010.

HUYBRECHTS, B.; DEFOURNY, J. Are fair trade organisations necessarily social enterprises? Social Enterprise Journal.V.4(3):186-201. 2008. Disponível em: http://www.emeraldinsight.com/10.1108/17508610810922695. Acesso em: Out/2010.

HYNES, B. Growing the social enterprise: issues and challenges. Social Enterprise Journal. V.5(2):114-125. 2009. Disponível em: http://www.emeraldinsight.com/10.1108/17508610910981707. Acesso em: Out/2010.

ISLAM, Z. U. A new model for supporting social enterprise through sustainable investment. Social Enterprise Journal. V.3(1):1-9. 2007. Disponível em: http://www.emeraldinsight.com/10.1108/17508610780000717. Acesso em: Out/2010.

JONES, D.; KEOGH, W. Social enterprise: a case of terminological ambiguity and complexity. Social Enterprise Journal. V.2(1):11-26. 2006. Disponível em: http://www.emeraldinsight.com/10.1108/17508610680000710. Acesso em: Out/2010.

KASIM, R.; HUDSON, J. FM as a social enterprise. Facilities.V.24(7/8):292-299. 2006. Disponível em: http://www.emeraldinsight.com/10.1108/02632770610666143. Acesso em: Out/2010.

KEATS, B.W.; BRACKER, J. S. Toward a theory of small firm performance: A conceptual model. American Journal of Small Business 12:41-58. 1988.

KERLIN, Janelle. Social Enterprise in the United States and Europe: Understanding and Learning from the Differences", Voluntas - International Journal of Voluntary and Nonprofit Organizations, v. 17, n. 3, p. 247 - 263, 28/09/2006. Disponível em: http://www.springerlink.com/content/e5070w063675np08/. Acesso em 14 de jun. 2010. 
LARATTA, R. Autonomy and accountability in social services nonprofits: Japan and UK. Social Enterprise Journal. 2009;5(3):259-281. Disponível em: http://www.emeraldinsight.com/10.1108/17508610911004331. Acesso em: Out/2010.

LAW FOR CHANGE. Disponível em: http://www.lawforchange.org/lfc/NewsBot.asp?MODE=VIEW\&ID=3922\&SnID=2.

Acesso em: 29 de maio de 2011.

LEIDECKER, Joel K., BRUNO, Albert V. Identifying and Using Critical Success Factors. Long Range Planning. Vol. 17, no 1, p. 23-32. 1984

LINDSAY, G.; HEMS L. Sociétées Coopératives d' Intérêt Collectif: The Arrival of Social Enterprise Within the French Social Economy. English.v.15(3). 2004.

LOW, C. A framework for the governance of social enterprise. International Journal of Social Economics. V.33(5/6):376-385. 2006. Disponível em: http://www.emeraldinsight.com/10.1108/03068290610660652. Acesso em: Out/2010.

LUKE, B.; VERREYNNE, M. L. Social enterprise in the public sector. MetService: thinking beyond the weather. International Journal of Social Economics. V.33(5/6):432$445.2006 . \quad$ Disponível em: http://www.emeraldinsight.com/10.1108/03068290610660698. Acesso em: Out/2010.

LYNCH, D.; ELliOTT, B. A.; BROCK, D. D. Appalachian By Design: lessons on creating social value. Social Enterprise Journal. V.4(3):229-241. 2008. Disponível em: http://www.emeraldinsight.com/10.1108/17508610810922712. Acesso em: Out/2010.

LYON, F.; RAMSDEN, M. Developing fledgling social enterprises? A study of the support required and means of delivering it. Social Enterprise Journal.V.2(1):27-41. 2006. Disponível em: http://www.emeraldinsight.com/10.1108/17508610680000711. Acesso em: Out/2010.

LYON, F.; SEPULVEDA, L. Mapping social enterprises: past approaches, challenges and future directions. Social Enterprise Journal. V.5(1):83-94. 2009. Disponível em: http://www.emeraldinsight.com/10.1108/17508610910956426. Acesso em: Out/2010.

MALHOTRA, Naresh. Pesquisa de Marketing: uma Orientação Aplicada. Porto Alegre: Bookman, 2001.

MANCINO, A. An Italian Pattern The Social Cooperative. Spring. V.15(3):357-370. 2005.

MANFREDI, F. Social Responsibility in the Concept of the Social Enterprise as a Cognitive System. International Journal of Public Administration. V.28(9-10):835-848. 2005.

Disponível

em:

http://www.informaworld.com/openurl?genre=article\&doi=10.1081/PAD-

200067371\&magic $=$ crossref $\|$ D404A21C5BB053405B1A640AFFD44AE3 Acesso em: Out/2010.

MARQUES, Patrícia; REFICCO, Ezequiel; BERGER, Gabriel. Negocios Inclusivos en America Latina. Harvard Business Review, Maio, 2009. 
MARTINS, G. A. Estudo de Caso: Uma Estratégia de Pesquisa, v.2, Editora Atlas, São Paulo, 2008.

MARTINS, G. A. Manual para elaboração de Monografias e Dissertações, v.3 p.6364, Editora Atlas, São Paulo, 2007.

MASON, C.; KIRKBRIDE, J.; BRYDE, D. From stakeholders to institutions: the changing face of social enterprise governance theory. Management Decision. V.45(2):284-301. 2007. Disponível em: http://www.emeraldinsight.com/10.1108/00251740710727296. Acesso em: Out/2010.

MASON, C.; KIRKBRIDE, J.; BRYDE, D. From stakeholders to institutions: the changing face of social enterprise governance theory. Management Decision. V.45(2):284-301. 2007. Disponível em: http://www.emeraldinsight.com/10.1108/00251740710727296. Acesso em: Out/2010.

MASON, Jennifer. Qualitative Researching. London: Sage Publications, 1996.

MASSETTI, B. L. The social entrepreneurship matrix as a "tipping point" for economic change. Emergence: Complexity and Organization. V.10(3):1-8. 2008. Disponível em: http://www.library.auckland.ac.nz/subjects/bus/docs/massetti.pdf. Acesso em: Out/2010.

MAWSON, J. Social enterprise, strategic networks and regional development: The West Midlands experience. International Journal of Sociology and Social Policy. V.30(1/2):66-83. $2010 . \quad$ Disponível em: http://www.emeraldinsight.com/10.1108/01443331011017047. Acesso em: Out/2010.

McBREARTY, S. Social enterprise: a solution for the voluntary sector? Social Enterprise Journal.v.3(1):67-77. 2007. Disponível em: http://www.emeraldinsight.com/10.1108/17508610780000722. Acesso em: Out/2010.

McCARTHY, B. Case study of an artists' retreat in Ireland: an exploration of its business model. Social Enterprise Journal. v.4(2):136-148. 2008. Disponível em: http://www.emeraldinsight.com/10.1108/17508610810902020. Acesso em: Out/2010.

McLOUGHLIN, J. et al. A strategic approach to social impact measurement of social enterprises: The SIMPLE methodology. Social Enterprise Journal.v.5(2):154-178. 2009. Disponível em: http://www.emeraldinsight.com/10.1108/17508610910981734. Acesso em: Out/2010.

MINARD, CSL. Valuing entrepreneurship in the informal economy in Senegal. Social Enterprise Journal. V. 5(3):186-209. 2009. Disponível em: http://www.emeraldinsight.com/10.1108/17508610911004304. Acesso em: Out/2010.

MOORE, J. F. The Death of Competition: Leadership \& Strategy in the Age of Business Ecosystems (Nueva York: HarperBusiness 1996), 26.

MOSSEL, JHV. ; STRAUB, A. Procurement of Dutch housing associations' technical management services: A decision framework. Property Management. V.25(5):487-501. 2007. Disponível em: http://www.emeraldinsight.com/10.1108/02637470710824748. Acesso em: Out/2010. 
MUNOZ, S-A Towards a geographical research agenda for social enterprise. Area. V.42(3):302-312. 2010. Disponível em: http://doi.wiley.com/10.1111/j.14754762.2009.00926.x. Acesso em: Out/2010.

MUNOZ, S-A. Social enterprise and public sector voices on procurement. Social Enterprise Journal. V.5(1):69-82. 2009. Disponível em: http://www.emeraldinsight.com/10.1108/17508610910956417. Acesso em: Out/2010.

MUNOZ, S-A.; TINSLEY, S. Selling to the Public Sector: Prospects and Problems for Social Enterprise in Prospects. 2008.

NAJAM, A. NGO Accountability: A Conceptual Framework. Development Policy. Review Vol. 14 (1996), 339-353. 1996

NDEMO, EB. Assessing sustainability of faith-based enterprises in Kenya. International Journal of Social Economics. V.33(5/6):446-462. 2006. Disponível em: http://www.emeraldinsight.com/10.1108/03068290610660706. Acesso em: Out/2010.

NIELSEN, C. ; SAMIA, PM. Understanding key factors in social enterprise development of the BOP: a systems approach applied to case studies in the Philippines. Journal of Consumer Marketing. V.25(7):446-454. 2008. Disponível em: http://www.emeraldinsight.com/10.1108/07363760810915662. Acesso em: Out/2010.

NWANKWO, E ; PHILLIPS, N. ; TRACEY, P. Social Investment through Community Enterprise: The Case of Multinational Corporations Involvement in the Development of Nigerian Water Resources. Journal of Business Ethics. V.73(1):91-101. 2006. Disponível em: http://www.springerlink.com/index/10.1007/s10551-006-9200-8. Acesso em: Out $/ 2010$

O'SHAUGHNESSY, M. Statutory support and the implications for the employee profile of rural based Irish work integration social enterprises (WISEs). Social Enterprise Journal. V.4(2):126-135. 2008. Disponível em: http://www.emeraldinsight.com/10.1108/17508610810902011. Acesso em: Out/2010.

OECD. Disponível em: http://www.oecd.org/Acesso em: 29 de maio de 2011.

OPSTAL, WV. ; DERADET, E. ; GIJSELINCKX, C. Monitoring profile shifts and differences among WISEs in Flanders. Social Enterprise Journal. V.5(3):229-258. 2009. Disponível em: http://www.emeraldinsight.com/10.1108/17508610911004322. Acesso em: Out/2010.

ORGANIZAÇÃO MUNDIAL DA SAÚDE, World Health Statistics, Global Health Observatory, 2010.2 Disponível em: http://www.who.int/whosis/whostat/EN_WHS10_Full.pdf. Acesso em 16 de janeiro de 2011.

ORGANIZATION FOR ECONOMIC CO-OPERATION AND DEVELOPMENT, OECD. "Social Enterprises", Paris, 1999.

PARKINSON, C. ; HORWORTH, C. The language of social entrepreneurs. Entrepreneurship \& Regional Development. V.20(3):285-309. 2008. Disponível em: 
http://www.informaworld.com/openurl?genre=article\&doi=10.1080/08985620701800507 $\&$ magic $=$ crossref||D404A21C5BB053405B1A640AFFD44AE3. Acesso em: Out/2010.

PEATTIE, K. ; MORLEY, A. Eight paradoxes of the social enterprise research agenda. Social Enterprise Journal. V.4(2):91-107. 2008 Disponível em: http://www.emeraldinsight.com/10.1108/17508610810901995. Acesso em: Out/2010.

PHILLIPS, SD. Will the Market Set Them Free ? Women , NGOs , and Social Enterprise in Ukraine. 2005.

PITTA, DA. ; KUCHER, JH. Social enterprises as consumer products: the case of vehicles for change. Journal of Product \& Brand Management. V.18(2):154-158. 2009. Disponível em: http://www.emeraldinsight.com/10.1108/10610420910949068. Acesso em: Out/2010.

PORTER, M. E. Competitive Advantage: Creating and Sustaining Superior Performance (Nueva York: Free Press, 1985).

PRABHU, GN. Social entrepreneurial leadership. Career Development International. V.4(3):140-145. $1999 . \quad$ Disponível em: http://www.emeraldinsight.com/10.1108/13620439910262796. Acesso em: Out/2010.

PRAHALAD, C. K. A Riqueza na Base da pirâmide: como erradicar a pobreza com o lucro. Wharton School Publishing, 2008.

REAY, K. Social enterprise. Nursing management (Harrow, London, England : 1994). V.16(1):8. 2009. Disponível em: http://www.ncbi.nlm.nih.gov/pubmed/20359407. Acesso em: Out/2010.

REFFICO, E. Empresas Sociales: Una especie en busca de reconocimento?, Revista de Administração da Universidade de São Paulo, São Paulo, v.41, n.4, p.404-418, out./nov./dez. 2006.2 Disponível em: http://www.rausp.usp.br/busca/artigo.asp?num_artigo=1208. Acesso em 13 de jun. 2010.

REFICCO, E. ; GUTIERREZ, R. ; TRUJILLO, D. "Empresas sociales: ¿una espécie en busca de reconocimiento?.” Revista Adm. São Paulo V. 41, no. n.4 . 2006. 404-418.

REFICCO, E. ; OGLIASTRI, E. ; RICA, C. Empresa y sociedad en América Latina: una introducción. Business and society in Latin America: An introduction. Society. V.125. 2009.

REFICCO, E. ; VERNIS, A. Market Ecosystem and Social Inclusion in: Socially Inclusive Business in Iberoamerica: challenges and opportunities. Social Enterprise Knowledge Network - SEKN. 2010.

REICHEL, J. ; RUDNICKA, A. Collaboration of NGOs and business in Poland. Social Enterprise Journal. V.5(2):126-140. 2009. Disponível em: http://www.emeraldinsight.com/10.1108/17508610910981716. Acesso em: Out/2010.

REID, K. ; GRIFFITH, J. Social enterprise mythology: critiquing some assumptions. Social Enterprise Journal. V.2(1):1-10. 2006. Disponível em: 
http://www.emeraldinsight.com/journals.htm?articleid=1728430\&amp;show=abstract.

Acesso em: Out/2010.

RIDLEY-DUFF, R. Communitarian Perspectives on Social Enterprise. Corporate Governance: An International Review. V.15(2):382-392. 2007. Disponível em: http://doi.wiley.com/10.1111/j.1467-8683.2007.00568.x. Acesso em: Out/2010.

RIDLEY-DUFF, R. Co-operative social enterprises: company rules, access to finance and management practice. Social Enterprise Journal. V.5(1):50-68. 2009. Disponível em: http://www.emeraldinsight.com/10.1108/17508610910956408. Acesso em: Out/2010.

RIDLEY-DUFF, R. Social enterprise as a socially rational business. International Journal of Entrepreneurial Behaviour \& Research. V.14(5):291-312. 2008 Disponível em: http://www.emeraldinsight.com/10.1108/13552550810897669. Acesso em: Out/2010.

ROCKART, J. F. Chief executives define their own data needs. Harvard Business Review, pp. 81-92, March-April (1979).

ROSA, M. V. F. P. C. ; ARNOLDI, M. A. G. C. A Entrevista na Pesquisa Qualitativa: mecanismos para validação dos resultados. 1 ed. 1. Reimp. Belo Horizonte: Autêntica, 2008. 112p.

ROTHEROE, N. ; MILLER, L. Innovation in social enterprise: achieving a user participation model. Social Enterprise Journal. V.4(3):242-260. 2008. Disponível em: http://www.emeraldinsight.com/10.1108/17508610810922721. Acesso em: Out/2010.

ROTHEROE, N. ; RICHARDS, A. Social return on investment and social enterprise: transparent accountability for sustainable development. Social Enterprise Journal. V.3(1):31-48. 2007. Disponível em: http://www.emeraldinsight.com/10.1108/17508610780000720. Acesso em: Out/2010.

ROTHSCILD, J. Workers' Cooperatives and Social Enterprise: A Forgotten Route to Social Equity and Democracy. American Behavioral Scientist. V.52(7):1023-1041. 2009 Disponível em: http://abs.sagepub.com/cgi/doi/10.1177/0002764208327673. Acesso em: Out/2010.

ROYCE, M. Using human resource management tools to support social enterprise: emerging themes from the sector. Social Enterprise Journal. V.3(1):10-19. 2007. Disponível em: http://www.emeraldinsight.com/10.1108/17508610780000718. Acesso em: Out/2010.

RTS. Disponível em: http://www.rts.org.br/noticias/destaque-2/fmusp-desenvolveaparelho-auditivo-digital-de-baixo-custo. Acesso em: 07 de junho de 2011.

RUDIO, F. V. Introdução ao projeto de pesquisa científica. 29, Ed. Petrolois, vozes, 2001. IN: MATIAS-PEREIRA, J. Manual de Metodologia da Pesquisa Científica, v.1, p.46, Editora Atlas, São Paulo, 2007.

RUYS, P. H. M. ; BRUIL, J. ;DIX, H. Modes of Governance in the Dutch Social Housing Sector. Annals of Public and Cooperative Economics. V.78(3):381-413. 2007. Disponível em: http://doi.wiley.com/10.1111/j.1467-8292.2007.00339.x. Acesso em: Out/2010. 
SALAMON, L. "A emergência do Terceiro Setor - uma revolução associativa global.”. Revista de Administração, São Paulo, 1998.

SAVITZ, A. W.; WEBER, K. A empresa sustentável: o verdadeiro sucesso é o lucro com responsabilidade social e ambiental. Tradução Afonso Celso da Cunha Serra - Rio de Janeiro. Elsevier. 2007.

SEANOR, P. ; MEATON, J. Learning from failure, ambiguity and trust in social enterprise. Social Enterprise Journal. V.4(1):24-40. 2008. Disponível em: http://www.emeraldinsight.com/10.1108/17508610810877713. Acesso em: Out/2010.

SEANOR, P. ; MEATON, J. Making sense of social enterprise. Social Enterprise Journal. V.3(1):90-100. 2007 Disponível em: http://www.emeraldinsight.com/10.1108/17508610780000724. Acesso em: Out/2010.

SEKN - Social Enterprise Knowledge Network. Disponível em www.sekn.org. Acesso em 21 de jan 2011.

SHAH, D. A UK policy perspective: thought piece from the UK Social Enterprise Coalition. Social Enterprise Journal. V.5(2):104-113. 2009. Disponível em: http://www.emeraldinsight.com/10.1108/17508610910981699. Acesso em: Out/2010.

SHANMUGAM, S. ; RAMAKRISHNA, V. S. ToeHold Artisans Collaborative: Building Entrepreneurial Capabilities to Tackle Poverty. Asian Case Research Journal. V.12(02):187. 2008. Disponível em: http://www.worldscinet.com/acrj/12/1202/S0218927508001114.html. Acesso em: Out/2010.

SHARPEN, C. Social enterprise under the microscope: comparing and contrasting Green-Works and ReBoot. Social Enterprise Journal. 2(1):101-113. 2006. Disponível em: http://www.emeraldinsight.com/10.1108/17508610680000716. Acesso em: Out/2010.

SHAW, E. Marketing in the social enterprise context: is it entrepreneurial ? 2004.

SHAW, E.; CARTER, S. Social entrepreneurship: Theoretical antecedents and empirical analysis of entrepreneurial processes and outcomes. Journal of Small Business and Enterprise Development. V.14(3):418-434. 2007. Disponível em: http://www.emeraldinsight.com/10.1108/14626000710773529. Acesso em: Out/2010.

SINGER, P. Introdução à Economia Solidária. Editora Fundação Perseu Abramo - $1^{\text {a }}$ ed. São Paulo. 2002.

SMITH, K. Embedding enterprise education into the curriculum at a research-led university. Education + Training. V.50(8/9):713-724. 2008. Disponível em: http://www.emeraldinsight.com/10.1108/00400910810917082. Acesso em: Out/2010.

SNAITH, I. Recent reforms to corporate legal structures for social enterprise in the UK: opportunity or confusion? Social Enterprise Journal. V.3(1):20-30. 2007. Disponível em: http://www.emeraldinsight.com/10.1108/17508610780000719. Acesso em: Out/2010. 
Social Enterprise Coaligtion. Disponível em: http://www.socialenterprise.org.uk/. Acesso em 07 de jan. 2011.

Social Enterprise Coalition. Disponível em: http://www.socialenterprise.org.uk/ Acesso em: 07 de jan. 2011.

SOUZA, A. N.; GORLA, J. I.; ARAÚJO, P. F.; LIFANTE, S. M.; CAMPANA, M. B. Análise da coordenação motora de pessoas surdas. Arq. Ciênc. Saúde Unipar, Umuarama, v. 12, n. 3, p. 205-211, set./dez. 2008.

SPEAR, R. ; BIDET, E. Social enterprise for work integration in 12 European countries: a descriptive analysis*. Annals of Public and Cooperative Economics. V.76(2):195-231. 2005. Disponível em: http://doi.wiley.com/10.1111/j.13704788.2005.00276.x. Acesso em: Out/2010.

SPEAR, R. ; CORNFORTH, C. ; AIKEN, M. The Governance Challenges of Social Enterprises: Evidence From a UK Empirical Study. Annals of Public and Cooperative Economics. V.80(2):247-273. 2009. Disponível em: http://doi.wiley.com/10.1111/j.14678292.2009.00386.x. Acesso em: Out/2010.

SPEAR, R. Social entrepreneurship: a different model? International Journal of Social Economics. $\quad$ v.33(5/6):399-410. 2006. Disponível em: http://www.emeraldinsight.com/10.1108/03068290610660670. Acesso em: Out/2010.

SRIDHAR, M. K.; NAGABHUSHANAM, Manasa. NGOs in India: Uniqueness and Critical Success Factors. VISION - The Journal of Business Perspective 1 Vol. 121 No. 21 April-June 2008.

TEODOSIO, Armindo. A disputa pelos pobres I. Disponível em: http://armindoteodosio.blogspot.com/2010/01/disputa-pelos-pobres-i.html. Acesso em: 29 de maio de 2011.

THOMAS, A. The Rise of Social Cooperatives in Italy. V.15(3). 2004.

THOMPSON, J. L. Social enterprise and social entrepreneurship: where have we reached?: A summary of issues and discussion points. Social Enterprise Journal. V.4(2):149-161. 2008. Disponível em: http://www.emeraldinsight.com/10.1108/17508610810902039. Acesso em: Out/2010.

TILLMAR, M. Societal entrepreneurs in the health sector: crossing the frontiers. Social Enterprise Journal. V.5(3):282-298. 2009. Disponível em: http://www.emeraldinsight.com/10.1108/17508610911004340. Acesso em: Out/2010.

TODRES, M. et al. Developing emerging social enterprise through capacity building. Social Enterprise Journal. V.2(1):61-72. 2006. Disponível em: http://www.emeraldinsight.com/10.1108/17508610680000713. Acesso em: Out/2010.

TRAVAGLINI, C. ; BANDINI, F. ; MANCINONE, K. "Social Enterprise Across Europe: a comparative study on legal frameworks and governance structures." 2008.

TREMBlAY, C. ; GUTBERLET, J. ; PEREDO, A. M. United We Can: Resource recovery, place and social enterprise. Resources, Conservation and Recycling. 
V.54(7):422-428.

2010.

Disponível

em:

http://linkinghub.elsevier.com/retrieve/pii/S0921344909002080. Acesso em: Out/2010.

TREXLER, J. Complexity and Philosophy Social Entrepreneurship as an Algorithm: Is Social Enterprise Sustainable? Matrix. V.10(3):65-85. 2008.

VANSANDT, C. V. ; SUD, M. ; MARME, C. Enabling the Original Intent: Catalysts for Social Entrepreneurship. Journal of Business Ethics. V.90(S3):419-428. 2010. Disponível em: http://www.springerlink.com/index/10.1007/s10551-010-0419-z. Acesso em: Out/2010.

VIDAL, I. Social Enterprise and Social Inclusion: Social Enterprises in the Sphere of Work Integration. International Journal of Public Administration. V.28(9-10):807-825. 2005. Disponível

em: http://www.informaworld.com/openurl?genre=article\&doi=10.1081/PAD-

200067347\&magic $=$ crossref || D404A21C5BB053405B1A640AFFD44AE3. Acesso em: Out/2010.

WHEELER, D. et al. Local Enterprise Networks. MIT Sloan Management Review. V.47(1). 2007.

WWHEARING. Disponível em: http://www.wwhearing.org/news/entry/the-poor-arehardest-hit-by-hearing-impairment. Acesso em: 07 de junho de 2011.

YIN, R. K. Estudo de Caso - Planejamento e Métodos, Bookman, Porto Alegre, v.3. 2005

YOUNG, D. A Unified Theory of Social Enterprise. Atlanta, GA: Georgia State University, Nonprofit Studies Program, Janeiro de 2007. Disponível em: http://aysps.gsu.edu/nonprofit/working/NSPwp0701.pdf. Acesso em 15 de jun. 2010.

YOUNG, D. Alternative Perspectives on Social Enterprise. In: CORDES, Joseph; STEUERLE, Eugene (eds.). Nonprofits and Business, Washington, D.C.: The Urban Institute Press, 2009.

YOUNG, D. R. A unified theory of social enterprise. In: SHOCKLEY, G. E.; STOUGH, R. R.; FRANK, P. M. (ed.). Non-market Entrepreneurship - Interdisciplinary Approaches. Cheltenham, UK: Edward Elgar Publishing. 2008.

YUNUS, M. ; MOINGEON, B. ; LEHMANN-ORTEGA, L. Building Social Business Models: Lessons from the Grameen Experience. Long Range Planning. V.43(2-3):308325.2010 .2 Disponível em: http://linkinghub.elsevier.com/retrieve/pii/S0024630109001290. Acesso em: Out/2010.

YUNUS, M. Creating a World Without Poverty: social business and the future of capitalism. 1a. Edição. 2007.

YUNUS, M. Credit for the Poor: Poverty as Distant History. Harvard International Review. 2007. Disponível em: http://hir.harvard.edu/index.php?page=article\&id=1654\&p=2. Acesso em 5 de jun. 2010. 


\section{ANEXO 1 - MÉTODO DO LEVANTAMENTO BIBLIOGRÁFICO}

Primeiramente, foi realizado um amplo levantamento em bases de dados de textos acadêmicos que se apropriam dos principais termos usados na temática desse trabalho. Foram pesquisadas em seis bases de dados, internacionais e nacionais, as seguintes palavras chave: empresas sociais, social enterprise, negócios inclusivos, inclusive business e negócios sociais, social business.

O levantamento levou em conta três principais termos referentes à temática desse trabalho que foram pesquisados em português para as bases de dados nacionais e em inglês para as bases internacionais e são eles: empresas sociais, social enterprise, negócios inclusivos, inclusive business e negócios sociais, social business. Os termos foram pesquisados em seis bases de dados, sendo as nacionais CAPES, EnAnpad e SEMEAD e as internacionais EBSCO, PROQUEST e ISI.

O levantamento dos trabalhos acadêmicos foi realizado durante os dias 21 a 24 de setembro de 2010. Os filtros adotados foram: "pesquisa em todas as bases"; "apenas textos completos"; "publicações acadêmicas, incluindo avaliadas por pares acadêmicos" e "todos os anos". Todos esses filtros foram usados nas seis bases e a repetição de artigos trazidos por diferentes bases foi eliminada.

Assim, em todas as bases buscou-se aproximar os mesmos parâmetros de pesquisa, conforme descrito a seguir. Em todas as bases foram quantificados como resultados pertinentes aqueles artigos que traziam textos completos, como citado anteriormente. Para a base nacional da CAPES, particularmente os periódicos CAPES, foi usada como área de avaliação a opção "administração, ciências contábeis e turismos" de circulação internacional e nacional e de qualificação A1 para Ciências Sociais aplicadas, Administração Pública e Contabilidade. A pesquisa foi realizada em nove diferentes Journals presentes nessa categoria dentre os periódicos CAPES. 


\section{Quadro 13 - Lista de Journals CAPES qualificação A1 na área de administração}

Ensaio : Avaliação e Políticas Públicas em Educação
Gestão e Produção
Organizações e Sociedade : O\&S
Pesquisa Operacional
RAE Eletrônica
Revista Contabilidade e Finanças
Revista de Administração Contemporânea : RAC
Revista de Administração de Empresas : RAE
Revista Eletrônica de Administração : REAd

Apenas dois dos nove journals retornaram artigos quando usada uma das palavras-chave escolhida para essa pesquisa. No total foram setenta e quatro artigos com textos completos, sendo cinqüienta artigos com a palavra chave "Empresas Sociais", dez com a palavra chave "Negócios Sociais" ambos provenientes da revista RAE e treze com a palavra chave "Empresas Sociais" da RAE eletrônica e apenas um com a palavra "negócios sociais" da RAE eletrônica.

A pesquisa com as três palavras-chave tanto nas bases dos congressos EnAnpad (Encontro Nacional da ANPAD - Associação Nacional de Pós Graduação e Pesquisa em Administração), quanto no SEMEAD (Seminários em Administração - USP) não retornou nenhum resultado de trabalho acadêmico, sendo que a base SEMEAD estava disponível até o congresso do ano de 2009.

O mesmo levantamento foi realizado nas bases internacionais procurando seguir os parâmetros acima descritos, sendo que todos deveriam conter o trabalho em sua íntegra.

Para a base EBSCO, a palavra-chave foi buscada no resumo do artigo. A pesquisa deveria retornar revistas acadêmicas (analisadas por especialistas) e periódicos científicos de todos os anos. Retornou com resultado quatorze artigos para Social Business, cinqüenta e cinco para Social Enterprise e três para Inclusive Business.

Para a base PROQUEST foram selecionados os itens: múltiplas bases de dados, com 
artigos de todas as datas, apenas documentos com texto completo, publicações acadêmicas, incluindo avaliadas por pares acadêmicos, com busca de termos em citação e resumo e tipo de publicação, as publicações acadêmicas exceto críticas literárias. Com essa pesquisa, retornaram vinte artigos para Social Business, cento e quinze para Social Enterprise e apenas um para Inclusive Business.

Para a base ISI, foi solicitada a busca em todas as bases de dados, para tipo de texto classificados como "documentos ou artigos", em todos os anos, apenas textos completos e termo no título ou no tópico. Nesta base, retornaram seis artigos para Social Business, dez para Social Enterprise, mas nenhum artigo retornou para o termo Inclusive Business.

No total foram quarenta artigos analisados em Social Business, cento e oitenta em Social Enterprise e quatro em Inclusive Business, ainda considerando aqui os artigos que poderiam estar repetidos.

Após eliminação dos artigos repetidos e daqueles fora do tema, a pesquisa internacional apresentou um resultado final de cento e oito artigos. Na pesquisa nacional, todos os artigos estavam fora do tema.

O resumo dos resultados retornados pela pesquisa na base está apresentado nas tabelas a seguir.

Tabela 2 - Número de artigos a partir de levantamento bibliográfico em bases nacionais de pesquisa

\begin{tabular}{|c|c|c|c|c|}
\hline \multirow{2}{*}{$\begin{array}{c}\text { Bases internacionais de } \\
\text { pesquisa }\end{array}$} & \multicolumn{3}{|c|}{ Termo } & \multirow{2}{*}{$\begin{array}{l}\text { Qtd } \\
\text { Total }\end{array}$} \\
\hline & Social Business & Social Enterprise & Inclusive Business & \\
\hline Proquest & 20 & 114 & 3 & 137 \\
\hline Ebsco & 14 & 54 & 1 & 69 \\
\hline ISI & 6 & 10 & 0 & 16 \\
\hline Total & 40 & 178 & 4 & 222 \\
\hline \multicolumn{5}{|l|}{ Filtros } \\
\hline Repetidos & 4 & 14 & 1 & 19 \\
\hline Total & 36 & 164 & 3 & 203 \\
\hline Fora do tema: & 33 & 61 & 1 & 95 \\
\hline Total & 3 & 103 & 2 & 108 \\
\hline
\end{tabular}


Tabela 3 - Número de artigos a partir de levantamento bibliográfico em bases internacionais de pesquisa

\begin{tabular}{|c|c|c|c|c|}
\hline \multirow{2}{*}{$\begin{array}{c}\text { Bases nacionais de } \\
\text { pesquisa }\end{array}$} & \multicolumn{3}{|c|}{ Termo } & \multirow{2}{*}{$\begin{array}{l}\text { Qtd } \\
\text { Total }\end{array}$} \\
\hline & Negócio Social & Empresa Social & Negócios Inclusivos & \\
\hline CAPES & 11 & 63 & 0 & 74 \\
\hline EnAnpad & 0 & 0 & 0 & 0 \\
\hline SEMEAD & 0 & 0 & 0 & 0 \\
\hline Total & 11 & 63 & 0 & 74 \\
\hline \multicolumn{5}{|l|}{ Filtros } \\
\hline Repetidos & 0 & 0 & 0 & 0 \\
\hline Total & 11 & 63 & 0 & 74 \\
\hline Fora do tema: & 11 & 63 & 0 & 74 \\
\hline Total & 0 & 0 & 0 & 0 \\
\hline
\end{tabular}

Esse levantamento possibilitou não só aprofundar a discussão teórica sobre o tema como também deu base para a elaboração do estudo prático, além de justificar o estudo de caso com este tema.

Os 108 trabalhos encontrados foram classificados em três dimensões baseadas nos objetivos propostos de cada trabalho: conceitual, gestão e impacto. Cada um dessas dimensões foi relacionada a uma das três perspectivas (Norte-americana, Européia e de países emergentes).

Tabela 4 - Perspectivas x Qualificantes

\begin{tabular}{cccc}
\hline & Conceitual & Gestão & Impacto \\
\hline Norte-americana & 7 & 8 & 0 \\
Européia & 31 & 34 & 13 \\
Países Emergentes & 3 & 9 & 3 \\
\hline TOTAL & $\mathbf{4 1}$ & $\mathbf{5 1}$ & $\mathbf{1 6}$ \\
\hline
\end{tabular}




\section{ANEXO 2 - ROTEIRO DE ENTREVISTA ${ }^{19}$}

O objetivo da entrevista é a análise apenas da iniciativa Solar Ear, que é inserida em diferentes organizações a cada país. As outras iniciativas que as organizações desenvolvem não são foco do estudo e têm importância secundária.

A seguir é apresentado o roteiro de entrevista completo.

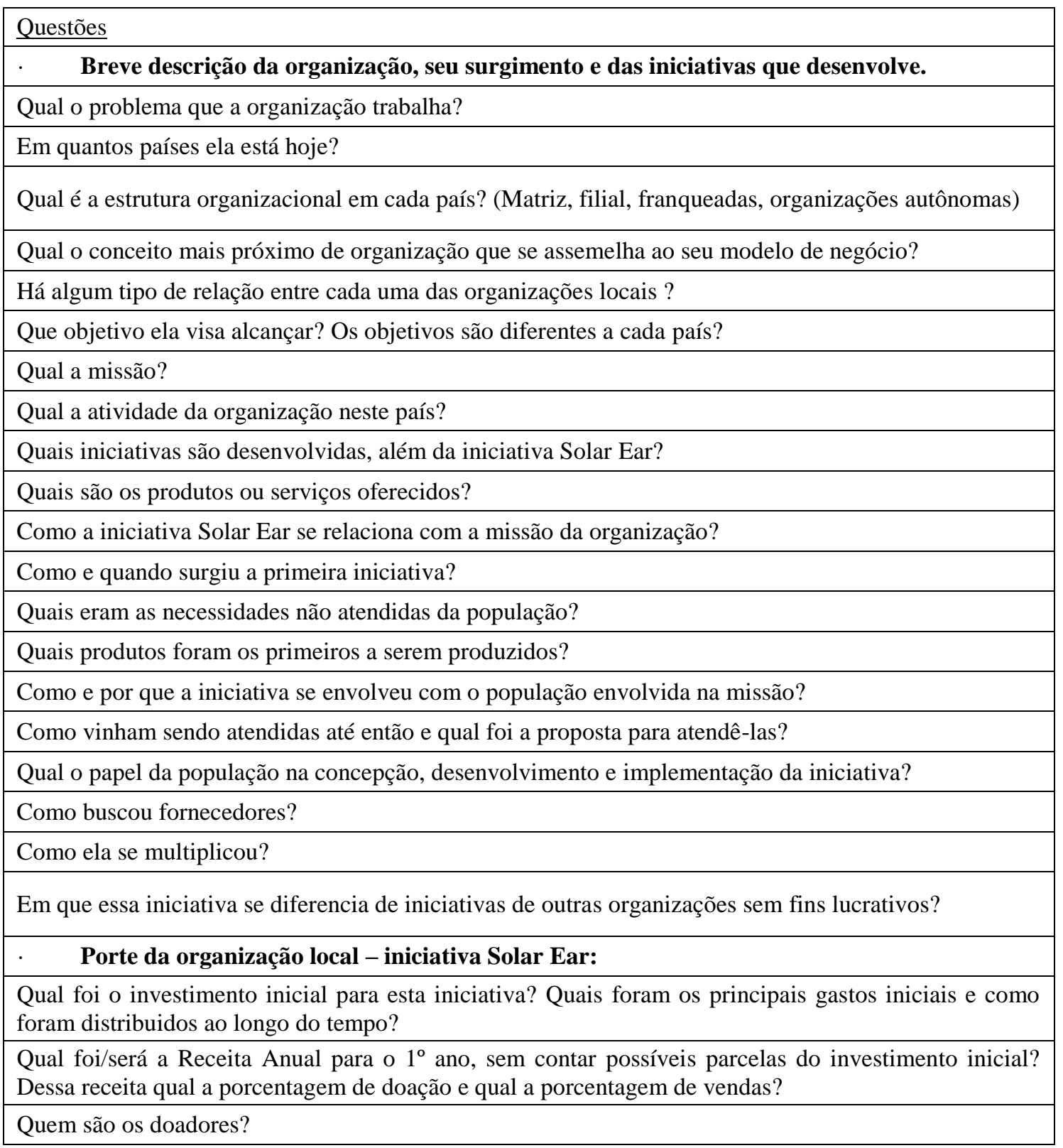

19 O roteiro de entrevista elaborado utilizou como base o protocolo de estudo feito pela rede SEKN referência Ciclo III de 26 de julho de 2006, adaptado conforme os objetivos propostos. 
Qual a dependência das doações para se sustentar? A organização é rentável apenas com vendas?

Existe um organograma da organização?

Qual o número de colaboradores (funcionários e voluntários)? Há consultores externos ou serviços de assessoria externo?

Quantas áreas internas existem?

Quais são as responsabilidades e atividades de cada colaborador?

Qual a inovação da sua organização no aspecto estrutura organizacional? Em que ela diferencia no âmbito social das outras empresas do mercado?

. Mercado e alcance geográfico da operação local

Quantos países consegue atingir com as vendas?

Qual a porcentagem de países pobres ou em desenvolvimento?

Qual o impacto social, ambiental ou econômico de seu produto?

Qual o perfil de seus clientes? Eles são os clientes finais?

Quantas são as pessoas que necessitam seu produto (nacional e mundial)?

Qual é o tamanho do mercado (numero de pessoas, poder de compra)? Qual é a participação da iniciativa estudada? Quantas empresas tem nesse mercado? Qual é o perfil dessas empresas?

Qual é o potencial de crescimento desse mercado?

Existem produtores nacionais?

Qual é sua participação no mercado nacional?

Qual são as principais características desse mercado?

Qual a inovação feita por sua organização para poder entrar no mercado?

Como a organização identificou a oportunidade de negócios?

. Cadeia produtiva

Como é dada a relação com os fornecedores? Quantos são eles?

Você acredita que exista alguma diferenciação nas relações dos fornecedores com a sua organização se comparado às outras empresas clientes?

Como é realizada a venda? Existe equipe de venda, revendedores ou distribuidores de seu produto?

Como é dada a relação com eles?

Quem é o cliente final? Como ele é beneficiado ao comprar o produto de sua organização?

. Contexto e cenário

Em que contexto foi inserido o negócio?

Quais as dificuldades específicas da implementação da organização nesse país?

Existe algum apoio do governo?

Você acredita que a legislação de seu país é favorável ou desfavorável para o bom andamento de sua organização? Existe algum outro aspecto institucional (forças políticas, legislação, necessidades sociais, "exclusão/inclusão", programas governamentais) que impacta no dia-a-dia de sua organização?

Quais são as principais características da população envolvida na iniciativa (características, renda, origens, histórico, ativismo, etc.)?

Como é a oferta/demanda por emprego para o perfil de funcionários que sua organização possui?

Você acredita que questões como exclusão social, vulnerabilidade e violência estão no dia-a-dia da população envolvida com a iniciativa de sua organização?

. Avaliação da estratégia da iniciativa 
Qual a inovação no modelo de negócio utilizado que permite a rentabilidade da organização?

Como tem sido o desenvolvimento de novos produtos ou o aperfeiçoamento dos existentes?

No âmbito social, em que o modelo de negócio desta iniciativa se diferencia dos modelos de negócio das outras empresas do mercado?

Se comparados aos produtos do mercado como é posicionado em relação a preço e qualidade?

Quais são as principais competências da organização que a tornam competitiva no mercado?

Qual o papel da população envolvida na iniciativa?

Quais fatores impedem ou podem impedir a organização de atender a esse mercado de forma rentável? (barreiras podem incluir: bases culturais e preconceitos, falta ou inadequação de informação sobre a população e suas necessidades, infra-estrutura insuficiente ou altos custos de distribuição, ambiente pouco amigável para a iniciativa privada, altos custos de transação, altos custos de governança, entraves institucionais, baixo poder de compra individual, necessidade de altos investimentos, etc.)

Você acredita que o valor social do produto seja um atrativo no mercado?

Quais fatores impedem ou podem impedir a população envolvida a ingressar nessa relação de negócio? (barreiras possíveis podem incluir: bases culturais e preconceitos, falta ou inadequação de informação sobre a organização e suas necessidades ou características, infraestrutura insuficiente ou nível educacional (condições sócio-econômicas), ambiente pouco amigável para a iniciativa privada (movimentos sociais organizados), dificuldade para conceber e desenvolver negócios, falta de capacidade financeira)

Foram tomadas medidas para reduzir o impacto dessas barreiras?

Foram feitas adaptações internas para superar essas barreiras?

Como o mercado está estruturado (considerar as 5 forças de Porter: ameaça de novos entrantes, poder de barganha dos fornecedores, ameaça de produtos ou serviços substitutos, poder de barganha dos compradores, rivalidade entre competidores)?

\section{. Liderança}

Quem foi o líder da iniciativa? Qua seu o perfil e as motivações?

Quais grupos de pessoas (times, unidades) foram ativamente envolvidos no desenvolvimento da iniciativa? Quais papéis cada um desses grupos desempenhou ao longo da evolução da iniciativa?

\section{- Governança}

O trabalho com essa população gerou alguma mudança nos sistemas de planejamento, tomada de decisão e accountability?

A população foi incorporada aos processos internos e estruturas da organização?

Qual é o regime de governança escolhido para essa organização? Por que os membros o escolheram?

Qual é o efeito desse modelo de governança na performance?

\section{. Cultura Organizacional}

De que modo a cultura organizacional facilita ou dificulta a iniciativa?

Existe alguma particularidade da população envolvida com a iniciativa que influencia a cultura organizacional?

De que modo a iniciativa da organização influencia a cultura da população?

Quais funções/cargos são fatores-chave no mercado em que a iniciativa se insere? Por quê?

Quais características e competências da população são fatores-chave no mercado em que a iniciativa se insere? Por quê? 
Qual o tipo de perfil profissional está envolvido com a iniciativa? Foi necessário trazer talentos externos (funcionários ou consultores) para participar da iniciativa? Por quê?

Quais competências pessoais são fundamentais para gerenciar a iniciativa?

Como elas se diferenciam daquelas que são requeridas para outros negócios?

Como será o Solar Ear quando as pessoas que hoje estão gerindo não estarão mais atuando?

Como a organização procura garantir que aquelas competências sejam desenvolvidas internamente?

\section{. $\quad$ Estrutura}

Como a iniciativa se insere na estrutura da organização?

Que opções (de inserção da iniciativa) a organização teve e por que foram descartadas?

Quais mudanças estruturais ocorreram (se ocorreram) desde que a organização se envolveu com a população?

\section{. Processos}

Quais são os processos chave (logística, distribuição, serviço ao cliente, marketing, P\&D, etc.)?

Para cada conjunto de processos relevantes, quais práticas têm sido desenvolvidas para gerenciar iniciativa e como elas se diferenciam das práticas já existentes para trabalhar com outros setores?

Quais inovações ocorreram (produtos, distribuição, precificação, etc.) e, se relevante, como se diferenciam de outras organizações?

Como a aprendizagem tem sido internalizada? A população foi incorporada, de alguma forma, nos processos operacionais? Como?

\section{. Avaliação de desempenho}

Como a organização avalia o desempenho da iniciativa?

Há alguma nova forma de avaliação (mensuração)?

O que falta fazer para incrementar o desenvolvimento da iniciativa?

Como a população avalia o desempenho da iniciativa?

$\underline{\text { Ecossistema }}$

\section{. $\quad$ Rede de Parceiros / Cadeia de valor}

Com quais atores/organizações que sua organização interage? Como é dada essa interação e por quê? Qual é o princípio utilizado que norteia a atual configuração?

Quais atores foram envolvidos no desenvolvimento da iniciativa? (comunidade/lideranças, ONGs, entidades estatais, outras empresas, etc.)

Quais papéis foram / são desempenhados por esses atores? Quais foram / são as contribuições e os ganhos desses atores?

Quais atores saíram, quais nunca participaram e quais foram incorporados ao longo do desenvolvimento e implantação da iniciativa? O que motivou essas mudanças?

Quais fatos determinaram essa configuração e esses pressupostos? Como os pressupostos estão internalizados pelos participantes da cadeia?

Quais barreiras estiveram / estão presentes na relação de cada participante com o restante da cadeia?

O que cada organização agregou / agrega para a iniciativa?

A organização estudada desempenha o papel de uma ponte entre outras organizações? Qual é o resultado de sua atuação? Quais são as organizações ligadas pela ponte?

De forma sintética, descreva as relações entre as organizações, isto é, os pontos de interação e os papéis assumidos pelos participantes. Qual é o papel da população envolvida pela organização nessas relações? 
Quais funções específicas a organização tem na cadeia (exemplos: condutora de idéias e inovações, fonte de informação, captação de recursos, negociadora de acordos, concebe estratégias, mediadora de conflitos)?

Quais funções específicas a população envolvida tem na cadeia (exemplos: condutora de idéias e inovações, fonte de informação, captação de recursos, negociadora de acordos, concebe estratégias, mediadora de conflitos, fornecedor menos custoso, comprador lucrativo, etc.)?

A organização contribui para a construção da capacidade local, mobilizando a população para ajuda mutua?

O governo desempenha algum papel no arranjo produtivo? Descreva (facilitador, catalisador, mediador, outros) Por outro lado, a iniciativa tem influenciado as políticas públicas?

Existem parcerias com outras organizações? Qual é a importância dessas parcerias? São parcerias intersetorial? Qual é a profundidade e a abrangência do alinhamento entre missões, valores e estratégias?

\section{. Capital Social}

Como se estabelece e se mantém a confiança entre os atores? Qual é o papel das relações pessoais?

Por que a organização realizou parcerias? (Para minimizar custos de transação, melhorar o posicionamento estratégico e obter aprendizagem organizacional)

Quais foram os maiores desafios encontrados pela organização na relação com outras organizações e como foram ou estão sendo resolvidos?

Quais foram os maiores desafios encontrados pela população envolvida na relação com as organizações participantes e como foram ou estão sendo resolvidos?

Para quais parceiros as questões abaixo têm algum tipo de importância e como eles lidam com elas?

- ganhos econômicos da transação,

- benefícios para os participantes,

- mudança nos mecanismos de governança (igualitário X semi-hierárquico)

- aumento da confiança entre os parceiros

- integração de equipes de diferentes culturas organizacionais no projeto

- resolução de conflitos

- compartilhamento de riscos

- divisão de recompensas (critérios, justiça)

A organização teve que promover adaptações internas para participar de alguma parceria? Quais foram essas adaptações?

A organização estava apta a entender o ambiente local e integrar-se a ele? Qual a importância dessa capacidade?

Quais ativos sociais (como tradições, cultura) a organização alavancou para criar vantagem competitiva?

\section{. $\quad$ Resultados e Impactos:}

Qual é o impacto do modelo de governança no desempenho da parceria?

Como o compromisso com a parceria impacta a performance da organização? Em que medida os objetivos iniciais foram atingidos?

Qual é o impacto da parceria no ambiente "societal"?

A parceria gera complementaridades e/ou sinergias? Descreva

Geração de Valor

. Valor Financeiro e Social 
Como essa iniciativa consegue se auto-sustentar (sustentavel financeiramente)? Ela é também rentável?

Demonstre que o caso é comercialmente viável. Pode ser demonstrado seu potencial, desde que com precisão:

Qual o ROS? (Retorno sobre vendas, isto é, lucro/venda)

Qual é o Turnover? (Retorno = vendas/ativos)

Qual é o ROA? (Retorno sobre ativos $=$ ROS X Turnover)

Qual é o ROE? (Retorno sobre capital = lucro/capital)

O valor econômico é gerado através de uma cadeia de valor multilateral? Se sim, como é dado a distribuição de recompensas?

Como o valor econômico criado para a população envolvida na iniciativa se compara com a situação anterior? Como se compara com outras opções disponíveis no mercado?

Qual é o valor social criado pela iniciativa? Como pode ser mensurado? (Dimensões possíveis: remoção de barreiras que impedem a inclusão social, assistência àqueles temporariamente fragilizados ou sem capacidade de expressão,, alívio dos feitos indesejáveis da atividade econômica.)

Como a iniciativa contribui para o desenvolvimento local? Como é mensurado?

Existe a possibiidade de impactos nos indicadores sociais e ambientais: IDH, saúde, renda, educação, expectativa de vida, violência, poluição ambiental, preservação ambiental, auto-estima, empregabilidade/nível de emprego?

Quais são as externalidades causadas pela iniciativa? Quais são os impactos negativos para a população e para os demais stakeholders? 


\section{ANEXO 3 - PROTOCOLO DE INVESTIGAÇÃO PARA ESTUDO DE CASO}

O protocolo de investigação tem por objetivo aumentar a confiabilidade da pesquisa bem como servir como orientação para o processo de coleta de dado (YIN, 2005).

A seguir serão usadas três divisões essenciais para a criação do protocolo:

(i) visão geral do projeto do estudo de caso, que inclui informações prévias do projeto (objetivos e carta convite aos entrevistados) e as questões chave que serão investigadas; (ii) procedimentos de campo, que inclui acesso aos entrevistados, recursos físicos para entrevistas, agenda clara, cronograma de entrevista e tempo de duração; (iii) guia para o relatório do estudo de caso.

O questionário entraria como um quarto item, porém ele já foi apresentado no Anexo 2 deste trabalho.

\section{$\underline{\text { Visão geral do estudo de caso }}$}

Título: Facilitadores e Dificultadores na Implementação de um Negócio inclusivo em Três Países de Diferentes Continentes

Objetivos do estudo: (i) discutir e agregar novos conhecimentos sobre o tema de negócio inclusivo, (ii) analisar as características do modelo de negócio da iniciativa Solar Ear aplicado em três diferentes contextos, segundo o conceito de ecossistemas, (iii) comparar nos estudos de caso de cada país os fatores que contribuem, de forma positiva e negativa, na implementação do negócio inclusivo.

Problema da pesquisa: quais são as características de um negócio inclusivo e quais fatores contribuem para sua implementação?

Perguntas da pesquisa: (i) Quais as características de negócios inclusivos, empresa social e negócios inclusivos? (ii) Qual a visão norte-americana, a visão européia e a visão dos países emergentes? (iii) Quais as principais semelhanças e diferenças entre elas? (iv) Quais são os pontos comuns em todos os entendimentos sobre negócios inclusivos? (v) O 
que diferencia negócios inclusivos de outras organizações? (vi) Qual a definição que será usada no trabalho? (vii) Como é a cadeia de valor/ cadeia produtiva onde o negócio inclusivo estudado está inserido? (viii) Qual a criação de valor econômico e qual a criação de valor social? (ix) Como é o sistema de valor ou cadeia estendida? (x) Quem são os atores fora da cadeia e como cada um desses atores interagem? (xi) Quais outros aspectos ecossistema (história, realidade social, econômica, política, cultural)? (xii) Quem são as organizações suporte? (xiii) Qual o modelo de governança utilizado? (xiv) Quais os principais desafios enfrentados em cada país na fase de implementação? (xv) Quais as facilidades/ dificuldades encontradas em cada região? (xvi) Quais os principais elementos necessários para um negócio inclusivo bem sucedido? (xvii) O que estimulou cada um dos negócios inclusivos a iniciar atividades? (xviii) Quais os principais desafios a serem superados? (xix) Quais os fatores críticos de sucesso em cada um dos países ou quais as características que asseguram uma implementação efetiva? (xx) Existem características de sucesso do modelo de negócio estudado que poderiam ser agregadas à definição de negócio inclusivo?

Proposições teóricas utilizadas: Teoria do Ecossistema, Teoria dos Fatores Críticos de Sucesso, Teoria dos Negócios Inclusivos.

Estrutura do trabalho: o presente trabalho está dividido em cinco capítulos. Capítulo 1: delimitação do problema de pesquisa, objetivos e justificativa; Capítulo 2: contextualização e evolução dos conceitos teóricos; Capítulo 3: procedimentos metodológicos para realização da pesquisa; Capítulo 4: análise comparativa de um modelo de negócio aplicado a três diferentes países; Capítulo 5: considerações finais e recomendações para futuras pesquisas.

Indivíduos envolvidos: Pesquisador, Entrevistados, Revisor e Tradutor.

Procedimentos adotados no estudo de campo

Aspectos metodológicos: Trata-se de uma pesquisa exploratória feito por meio de um estudo de caso de uma iniciativa presente em três países.

Setor alvo: Organizações privadas sem fins lucrativos ou não que implementaram a 
iniciativa Solar Ear

As organizações: Solar Ear Botsuana - Godisa; Solar Ear Brasil - CEFAC Associação Assistencial em Saúde e Educação; Solar Ear Jordânia - RSS

Coleta de dados: pesquisa realizada por entrevistas não estruturadas, com perguntas abertas e com roteiro para orientação.

Fontes de dados - Primárias: Entrevistas com fundador, gerência das três localidades, dois indivíduos da população envolvida (jovens trabalhadores Brasil e Botsuana) e stakeholders (cliente e fornecedor).

Fontes de dados - Secundárias: Internas: documentos oficiais, arquivos e registros internos; Externas: artigos, resenhas, mídia e publicações não acadêmicas.

Instrumentos de coleta - Dados primários: entrevistas individuais com o fundador da iniciativa, indivíduos com cargos gerenciais de cada país, população inserida, população cliente e outros stakeholders como parceiros de ações humanitárias.

Instrumentos de coleta - Dados secundários: enviados pelos entrevistados, normalmente por email, após solicitação do pesquisador e coletados por meio de levantamento junto à fontes internas e externas apresentadas anteriormente

\section{$\underline{\text { Guia para relatório do estudo de caso }}$}

Estrutura para o relatório do estudo de caso: estrutura analítica linear; narrativa simples, onde as informações da narrativa podem ser realçadas com tabelas, gráficos ou imagens (YIN, 2005).

Análise do estudo em cada país: análise cruzada.

Procedimentos adotados: gravação das entrevistas; transcrição das entrevistas; análise das respostas das entrevistas juntamente com os dados secundários, segundo objetivo proposto pelo trabalho; identificação das evidências; identidade real da organização e dos 
entrevistados; revisão da minuta do estudo de caso por outros acadêmicos e por alguns dos entrevistados. 